medRxiv preprint doi: https://doi.org/10.1101/2021.04.27.21255462; this version posted April 29, 2021. The copyright holder for this preprint

(which was not certified by peer review) is the author/funder, who has granted medRxiv a license to display the preprint in perpetuity.

It is made available under a CC-BY-NC-ND 4.0 International license.

\title{
Determinants of Obesity in West Africa: A Systematic Review
}

Kingsley Agyemang, Subhash Pokhrel, Christina Victor, Nana Kwame Anokye Division of Global Public Health, Department of Health Sciences, College of Health, Medicine and Life Sciences, Brunel University London.

Keywords: Obesity, West Africa, Determinants, Correlates, Public Health

Running title: Determinants of Obesity in West Africa.

Acknowledgements: The authors acknowledge the contributions of the Office of the President (Ghana) and Brunel Global Public Health Academy. The comments herein are those of the authors and not the aforementioned institutions.

\section{Corresponding author}

Kingsley Agyemang

Division of Global Public Health

Department of Health Sciences

College of Health, Medicine, and Life Sciences

Brunel University London

Kingsley.Agyemang@brunel.ac.uk

Conflict of interest: The authors declare no conflict of interest 
medRxiv preprint doi: https://doi.org/10.1101/2021.04.27.21255462; this version posted April 29, 2021. The copyright holder for this preprint (which was not certified by peer review) is the author/funder, who has granted medRxiv a license to display the preprint in perpetuity.

It is made available under a CC-BY-NC-ND 4.0 International license .

\begin{abstract}
Objectives: Obesity prevalence is increasing in West Africa. This study explores obesity determinants in West Africa to inform policy.

Methods: Scopus, Web of Science and PsycINFO were searched for relevant papers from March to April 2020. The search strategy included combinations of key words specific to each database. Eligibility criteria included studies on obesity determinants conducted in West Africa, and involving participants aged eighteen years and above. The quality of the studies was appraised using the Agency for Healthcare Research and Quality checklist. Data was synthesized qualitatively.
\end{abstract}

Results: Sixty-three (63) papers were selected. Majority of the studies originated from Ghana $(n=22)$ and Nigeria $(n=19)$. All included studies used cross-sectional study design. In all, 36 determinants were identified, of which 20 were demographic, socio-economic, lifestyle and biological factors, and sixteen 16 were environmental factors, like physical proximity to fast food outlets. Increasing age $(\mathrm{OR}=0.09,95 \% \mathrm{CI}=0.12$ to 65.91$)$ and being a woman $(\mathrm{OR}=1.38$, $95 \% \mathrm{CI}=1.18$ to 55.40 ) were the common determinants of obesity in West Africa.

Conclusion: Obesity in West Africa is determined by complex multi-faceted factors. There is an urgent need for robust engagement with wider stakeholder groups to develop obesity prevention and control policies in West Africa. 
medRxiv preprint doi: https://doi.org/10.1101/2021.04.27.21255462; this version posted April 29, 2021. The copyright holder for this preprint (which was not certified by peer review) is the author/funder, who has granted medRxiv a license to display the preprint in perpetuity. It is made available under a CC-BY-NC-ND 4.0 International license .

\section{Introduction}

Obesity is a global public health concern, and the World Health Organization (WHO) has estimated that it affects 650 million adults worldwide, with this burden projected to increase to one billion globally by $2030^{1,2}$. It is a modifiable risk factor for non-communicable diseases (NCDs), such as cardiovascular disease, type 2 diabetes, and various cancers ${ }^{2,3}$. In 2018, NCDs were responsible for 41 million (71\%) of the world's 58 million deaths, with 15 million dying prematurely ${ }^{4}$. Low- and middle-income countries, including Africa, bear over $85 \%$ of the burden of these NCDs premature deaths, resulting in cumulative economic losses of US\$7 trillion over the next 15 years and millions of people trapped in poverty ${ }^{5}$. Specifically, deaths from NCDs are likely to increase by $27 \%$ (about 28 million additional deaths) in Africa and are projected to exceed other deaths combined by 2030 in the region countries ${ }^{6}$.

Until recently, Africa was minimally affected by the obesity epidemic due to the burden of under-nutrition, HIV/AIDs, and tuberculosis ${ }^{7}$. However, current evidence shows that the continent is experiencing a swift rise in overweight and obesity prevalence as well as its associated co-morbidities because of a rapid ongoing nutritional and epidemiological transitions ${ }^{7,8,9}$. These dynamics, coupled with the epidemic of NCDs, create an urgent need for evidence-based sustainable actions to mitigate the obesity burden in Africa.

In West Africa, one of WHO's Africa subregions, about 52million people are with obesity, making it one of the subregions burdened with the obesity epidemic ${ }^{10}$. Based on this, obesity prevention and control policies have been implemented to address the epidemic. Key among them is the National Policy for the Prevention and Control of Chronic Non-Communicable Diseases (NCDs) in Ghana, the National Policy on Food and Nutrition (NPFN) in Nigeria and the National Food and Nutrition Security (NFNS) in Sierra Leone. Although these policies have created awareness about the obesity problem in West Africa, the prevalence of obesity continues to increase exponentially ${ }^{11,12}$. One primary reason for the shortfall of the obesity policies in West Africa is its inability to capture, holistically, all the determining factors of obesity ${ }^{13,14}$. Also, there is limited evidence to guide the implementation of these policies. 
medRxiv preprint doi: https://doi.org/10.1101/2021.04.27.21255462; this version posted April 29, 2021. The copyright holder for this preprint (which was not certified by peer review) is the author/funder, who has granted medRxiv a license to display the preprint in perpetuity. It is made available under a CC-BY-NC-ND 4.0 International license .

Several obesity determinants that could inform obesity prevention and control policies are identified in the literature. However, most of these determinants were discovered in highincome-countries (HICs); thus, they do not provide setting-specific obesity interventions/policies for West African countries. Hence, there is an unmet demand for a review of the determinants of obesity in West Africa. Therefore, this study aims to review factors associated with obesity in West Africa to inform context-specific interventions to address the obesity epidemic on the subregion. The findings may also provide recommendations for future empirical research in other LMICs.

\section{Methods}

Search strategy

Three electronic databases, Scopus, Web of Science and PsycINFO, were searched from March to April 2020 (updated search conducted from January to February 2021) for eligible studies using all possible combinations of search terms related to obesity determinants and Africa (Table 1). References of the papers identified in the electronic search were also screened for relevant studies. Identified studies were screened against the following eligibility criteria: (a)Quantitative studies that explored the determinants of obesity, (b) Studies written in the English language given the limited resources for translation, (c) Studies with participants aged eighteen years and above, and (d) Studies that used samples from West Africa settings.

(INSERT TABLE 1)

\section{Data extraction}

Two independent reviewers extracted relevant data from the selected studies using standardized data extraction questions developed a priori. The data extraction questions included information on the general characteristics of the studies, such as authors name and year of publication; methodological features like sample size and sample characteristics; and findings and recommendations from the authors. The questions were reviewed and agreed on by all the authors and pilot-tested before their usage. To ensure the quality of data extraction, $50 \%$ of the included papers were randomly selected and reviewed by a third reviewer. Any disagreements above $5 \%$ were resolved by consensus or through the opinion of another independent reviewer. 
medRxiv preprint doi: https://doi.org/10.1101/2021.04.27.21255462; this version posted April 29, 2021. The copyright holder for this preprint (which was not certified by peer review) is the author/funder, who has granted medRxiv a license to display the preprint in perpetuity.

\section{Quality appraisal}

Two reviewers appraised the quality of the selected papers using the Agency for Healthcare Research and Quality (AHRQ) methodology Checklist to reflect the cross-sectional design of all included studies. The AHRQ assessed the quality of the included studies based on eleven checklists. For each question, a score of one (1) was given if the study met it and zero (0) if the study did not meet it. The scores of the questions were summed to represent the total score for each study. The total score for meeting all the criteria on the AHRQ checklist was eleven. None of the studies was classified as high quality since none of them met all the eleven checklists. Their scores ranged from 4 to 9, indicating a low to medium quality. Table 2 shows the number of studies that met each of the AHRQ checklist criteria.

\section{(INSERT TABLE 2)}

\section{Data Synthesis/Analysis}

Descriptive synthesis of data was performed to describe the methods, operationalization of methods, major limitations, suggestions, and recommendations for future research. Where appropriate, for each of these domains, the synthesis compared the findings from across the studies so that the themes could be put into wider perspectives.

\section{Results}

A total of 4,085 records were identified from the database searches; however, only sixty-three met the inclusion criteria (figure 1). All the sixty-three papers were cross-sectional studies. Majority of them used primary data $(n=44)$ while the remaining used secondary data. Structured questionnaires were the common instruments used in collecting the data. The sample size of the studies that used primary data ranged from 59 to 6,959, and that of studies with secondary data ranged from 600 to 1,225,816. Fifty-five of the studies focused on only one West African country, mainly Ghana $(n=22)$, Nigeria $(n=19)$, Cameroon $(n=4)$, Burkina Faso $(n=3)$, Cote d' Ivoire $(n=2)$, Senegal $(n=2)$, Togo $(n=1)$, Gambia $(n=1)$, Benin $(n=1)$ while eight of them 
medRxiv preprint doi: https://doi.org/10.1101/2021.04.27.21255462; this version posted April 29, 2021. The copyright holder for this preprint (which was not certified by peer review) is the author/funder, who has granted medRxiv a license to display the preprint in perpetuity. It is made available under a CC-BY-NC-ND 4.0 International license .

focused on a combination of West African countries like Mali, Sierra Leone, Guinea, Liberia and Niger. All the studies were published between 2003 and 2019, with most of them in 2016 (n=10) and $2017(\mathrm{n}=10)$.

\section{(INSERT FIGURE 1)}

\section{Measurement of determining variables}

This review identified several determinants in the included studies. These determinants are categorised into demographic, socio-economic, biological, lifestyle and environmental variables, based on the Dahlgren and Whitehead ecological model of public ${ }^{15}$. The demographic variables included age and sex; socio-economic variables included level of education and employment status; biological variables comprised presence of hypertension, diabetes and hypercholesterolemia; lifestyle variables encompassed cigarette smoking, physical activity score, dietary score and alcohol consumption; and the environmental variables focused on neighborhood characteristics, like access to convenient stores and presence of recreational facilities, and extent of globalisation- which was an aggregate of social, political and economic globalisation that the study participants were exposed to.

\section{Definition/Measurement of obesity}

All sixty-three studies defined obesity based on the WHO BMI measurement of obesity. Thus, they classified BMI of $<18.5 \mathrm{~kg} / \mathrm{m}^{2}$ as people with underweight, $18.5-25 \mathrm{~kg} / \mathrm{m}^{2}$ as people with normal weight, $25.0-29.9 \mathrm{~kg} / \mathrm{m}^{2}$ as people with overweight and $\mathrm{BMI} \geq 30.0 \mathrm{~kg} / \mathrm{m}^{2}$ as people with obesity. Additionally, three of the studies further measured obesity body fat ${ }^{16}$ and abdominal obesity ${ }^{17,18}$. Percentage body fat $(\mathrm{BF} \%)$ was estimated using the following formula Adult body fat $\%=(1.20 \times \mathrm{BMI})+(0.23 \times$ Age $)-(10.8 \times \mathrm{sex})-5.4$. The cut-offs for $\mathrm{BF} \%$ for men and women were $25 \%$ and $30 \%$, respectively. Abdominal obesity was classified as a waist circumference of $\geq 102 \mathrm{~cm}$ in men or $\geq 88 \mathrm{~cm}$ in women, per WHO definition. Among the 44 papers that collected primary data, 32 of them used self-reported height and weight measures to estimate the BMI of the participants. Table 3 and 4 provide summary of the study characteristics, including measured variables. 
medRxiv preprint doi: https://doi.org/10.1101/2021.04.27.21255462; this version posted April 29, 2021. The copyright holder for this preprint

(INSERT TABES 3 AND 4)

\section{Empirical findings on the determinants of obesity in West Africa}

Sex was one of the common demographic variables identified in the included studies. Eleven out of the studies ${ }^{19,20,21,22,23,24,25,26,27,28,29}$ found women to be a significant determinant of obesity when the influence of other variables like age, marital status, education level and employment status are controlled. These studies were from Ghana $(n=3)$, Nigeria $(n=5)$, Nigeria \& Ivory Coast (combined) $(n=1)$ and Senegal $(n=2)$. Increasing age was also found as a demographic determinant of obesity in this review ${ }^{19,20,24,25,26,27,30,31,32}$ across Ghana $(n=2)$, Nigeria $(n=5)$, Burkina Faso $(n=1)$, Senegal $(n=1)$. In terms of biological factors, only two studies ${ }^{19,33}$ found hypertension and diabetes as positive determinants of obesity. These findings were from Ghana and Nigeria.

Regarding lifestyle variables, four of the studies, one each from Ghana ${ }^{36}$, Burkina Faso ${ }^{30}$ and Cameroon $^{34}$, and one from thirteen combined countries, namely: Benin, Burkina Faso, Cameron, Ivory Coast, Gambia, Ghana, Guinea, Mali, Niger, Nigeria, Liberia, Senegal, Sierra Leone and $\mathrm{Togo}^{35}$, found cigarette smoking to be significantly associated with obesity. Similarly, four of the studies from Ghana ${ }^{25,36}$, Nigeria ${ }^{19}$ and Burkina Faso $^{30}$ found alcohol consumption as a determinant of obesity. Also, ten studies Nigeria ${ }^{19,40}(n=2)$, Ghana ${ }^{23,25,28,37,38,41}(n=6), \operatorname{Togo}^{39}$ $(n=1)$ and Cameroon ${ }^{34}(n=1)$ indicated that lack and low levels of physical activity showed that physical activity is significantly associated with obesity. Additionally, ${ }^{42,}{ }^{28}$ from Nigeria and Ghana found poor dietary habits as determinants of obesity. All these lifestyle variables were identified as determinants after the studies had controlled for other measured variables.

The socio-economic variables that were identified in the selected papers as determinants of obesity are education level $(n=9)$, employment status $(n=3)$ and Socio-economic status $(n=3)$. These studies were also from Ghana $(n=2)$, Nigeria $(n=4)$, Togo $(1)$, Burkina Faso $(n=1)$ and Cameroon $(n=1)$. Of the environmental factors, most of the variables and the subsequent findings were heterogeneous across all the six studies that measured environmental factors. For instance, Dake et al. (2016)'s ${ }^{43}$ study on the influence of local food environment in a poor urban setting on 
medRxiv preprint doi: https://doi.org/10.1101/2021.04.27.21255462; this version posted April 29, 2021. The copyright holder for this preprint (which was not certified by peer review) is the author/funder, who has granted medRxiv a license to display the preprint in perpetuity. It is made available under a CC-BY-NC-ND 4.0 International license .

obesity discovered that for every additional convenience store in poor urban settings in Ghana, there was a $0.2 \mathrm{~kg} / \mathrm{m} 2$ increase in BMI, and every out-of-home cooked food place available, there was a $0.1 \mathrm{~kg} / \mathrm{m} 2$ reduction in BMI of residents while the study by Osayomi and Orhiere (2017) on environmental factors and obesity in Nigeria identified that physical proximity to fast food outlets is a determinant of obesity. See tables 4 and 5 for a summary of the review.

(INSERT TABLE 5) 
medRxiv preprint doi: https://doi.org/10.1101/2021.04.27.21255462; this version posted April 29, 2021. The copyright holder for this preprint (which was not certified by peer review) is the author/funder, who has granted medRxiv a license to display the preprint in perpetuity. It is made available under a CC-BY-NC-ND 4.0 International license .

\section{Discussion}

This review aimed to explore the determinants of obesity in West Africa, one of Africa's subregions currently experiencing a rise in obesity prevalence. Sixty-three studies, mainly from Ghana, Nigeria, Cameroon, Burkina Faso, Cote d' Ivoire, Senegal, Togo, Benin and Mali were included in this review. The identified determining factors were categorised into demographic, socio-economic, biological, lifestyle and environmental factors. The findings of this review will be discussed based on these categorisations.

In terms of demographic factors, the review identified being a woman and increasing age as common determinants of obesity. One possible explanation for sex differences in obesity determinants is the influence of gonadal steroids on adipose tissue storage and distribution ${ }^{45}$. Evidence from several studies suggests the endocrine mechanism as the cause of the different obesity phenotypic expressions across $\operatorname{sex}^{46-48}$. The endocrine pathway predisposes women to have a higher likelihood of having obesity than males in given population. Also, natural processes, like menopause, influence sex variations in obesity prevalence. Women are more inclined to undergo hormonal changes, which can affect glucose regulation, during menopause, and this consequently could predispose them to increased risk of obesity ${ }^{49,50}$. Regardless of these hormonal explanations, evidence also shows that gender, as a social construct, also predisposes to obesity than men ${ }^{51,52}$. Women are less likely to engage in physical activities ${ }^{51,53}$ and more likely to consume foods high in added sugars, such as chocolate and ice-cream than men ${ }^{54}$. However, they are more likely to report healthy eating practices ${ }^{55}$. Additionally, studies indicate that most West African women settle for more sedentary occupations, like petty and table trading; as such, they remain less physically active and subsequently store more body fat ${ }^{52,56}$. Also, data indicates that in most populations, particularly in LMICs, gender-based food preferences, likely to be influenced by one's socio-cultural orientation, exists and these could inadvertently result in gender variations in obesity prevalence preferences ${ }^{55,57}$. Furthermore, studies have shown that most West African communities admire women with large body size ${ }^{58-}$ ${ }^{60}$; thus, most of the women deliberately gain weight to meet these socio-cultural expectations.

The association between increasing age and obesity is also attributed to hormonal/metabolic changes that occur with ageing ${ }^{61-64}$. Ageing is associated with metabolic imbalance, which is a 
medRxiv preprint doi: https://doi.org/10.1101/2021.04.27.21255462; this version posted April 29, 2021. The copyright holder for this preprint (which was not certified by peer review) is the author/funder, who has granted medRxiv a license to display the preprint in perpetuity. It is made available under a CC-BY-NC-ND 4.0 International license .

significant contributor to obesity ${ }^{63}$. The increase in perivascular adipose tissue associated with ageing influences the risk of obesity among the aged population ${ }^{64}$. Moreover, ageing is also associated with less physical activities because of musculoskeletal changes, like reduced joint spaces and osteoporosis, that occur with ageing ${ }^{65}$. As most developing countries undergo demographic transition, the increasing burden of conditions, like obesity, is expected ${ }^{66}$. Also, an increase in life expectancy is usually correlated with increase susceptibility with chronic diseases, like diabetes, that is also associated with obesity ${ }^{63}$. Nonetheless, the association between ageing and obesity can go both ways, as obesity can also hasten ageing phenotypic development ${ }^{67}$. These findings on ageing and obesity re-enforce the need for stakeholders to map specific levels of interventions targeted at reducing disease burdens associated with ageing ${ }^{68}$

Education level, employment status and socio-economic status were the identified socioeconomic determinants of obesity. Studies ${ }^{59,60,69}$ show that large body size is usually tied to affluence and social status in West African countries, like Ghana and Nigeria. Therefore, individuals with high education and employment status may tend to gain weight to keep up with the social status that comes with affluence ${ }^{70}$. Also, wealth usually comes with increased purchasing power, and this inherently increases accessibility to food choices that can be abused $^{71}$. Additionally, most fast-food outlets are in affluent neighbourhoods to attract highearning clienteles to ensure business viability. This creates obesogenic environments that can be a catalyst for obesity ${ }^{71}$. Furthermore, the centralised systems of most West African countries put residential areas in city peripheries and work environments in city centres ${ }^{72}$. Thus, most people would have to commute long distances to and from work. Consequently, most workers would stay late at work to beat heavy traffic from the centre to the periphery of cities. These could induce stress and result in late eating, factors that have been implicated in the obesity epidemic ${ }^{72}$. The argument on high education and employment status and obesity can also hold for individuals low on the education and employment strata. For such individuals, their food choices are influenced mainly by their affordability ${ }^{73}$. This, however, does not necessarily translate into healthy food choices that could reduce their risk of obesity ${ }^{74}$.

The findings of this review are similar to the review findings of other reviews in both LMICS and $\mathrm{HICs}^{70,75-79}$. However, they were also inconsistent with other review ${ }^{80}$. The review found 
medRxiv preprint doi: https://doi.org/10.1101/2021.04.27.21255462; this version posted April 29, 2021. The copyright holder for this preprint (which was not certified by peer review) is the author/funder, who has granted medRxiv a license to display the preprint in perpetuity. It is made available under a CC-BY-NC-ND 4.0 International license .

men to be the common determinant of obesity as opposed to the finding of this review. This difference may be attributed to differences in sample characteristics.

Policy implications of review findings

The findings of this review indicate the need for specific policies to curtail the obesity epidemic in West Africa and, subsequently, other LMICs. These policies could include implementation of interventions to address gendered eating behaviours and education on socio-cultural weight perceptions and body image from the community-level up to the national level. Also, community-based physical activity interventions, appropriate for all age brackets, could be instituted in schools, churches and other social organisations to address age-related obesity incidence. Additionally, governments, through stakeholder engagements could address obesogenic environments by increasing accessibility and affordability of local foods rich in fibres, minerals, and vitamins, and reduce consumption of foods high in added salts and sugars at all population levels. Furthermore, governments could implement policies, such as decentralisation of government systems and enabling local economies, to reduce rural-urban migration, which is consequential in the obesity menace. Finally, social marketing approaches must be strategised to ensure obesity awareness to elicit favourable changes at individual and environmental levels.

\section{Strength and limitations of this review}

To the best of the researcher's knowledge, this is the first study to review the determinants of obesity in West Africa. Therefore, the findings could serve as a foundation for other future reviews/studies on obesity determinants in West Africa, in addition to providing a menu of policy options for West African nations and wider LMICs on obesity prevention and control. Also, this review included many studies; hence, it presents with more robust evidence on the determinants of obesity, and this could influence policy shift in the conceptualisation of relevant policies on obesity in West Africa. Even though this review included studies from most West African countries, there was a significant imbalance in the country representation because $65 \%$ of the studies were from Nigeria and Ghana. Thus, the evidence on the determinants of obesity in the underrepresented countries is limited. Furthermore, the heterogeneity across the reviewed studies could have influenced the conclusions of this review, and subsequently, the implications 
as discussed above. Thus, caution must be taken in the interpretation of this review findings to avoid biased inferences.

\section{Conclusion and Recommendation}

The findings of this review indicated that obesity in West Africa is determined by demographic, lifestyle, biological and socio-economic factors such as age, sex, physical activity, and education. These findings present an urgent need for robust engagement with broader stakeholder groups to develop sustainable obesity prevention and control policies to address the obesity epidemic in West Africa. These policies could include education, awareness and implementation of diet and physical activity interventions to stimulate individual and environmental changes at subpopulation and population levels. This review recommends that future studies are conducted in other African subregions, like East Africa, to provide evidence on determinants of obesity to proffer obesity interventions that would have far-reaching benefits to the broader African continent. 
medRxiv preprint doi: https://doi.org/10.1101/2021.04.27.21255462; this version posted April 29, 2021. The copyright holder for this preprint (which was not certified by peer review) is the author/funder, who has granted medRxiv a license to display the preprint in perpetuity.

It is made available under a CC-BY-NC-ND 4.0 International license.

\section{LIST OF FIGURE AND TABLES}


medRxiv preprint doi: https://doi.org/10.1101/2021.04.27.21255462; this version posted April 29, 2021. The copyright holder for this preprint (which was not certified by peer review) is the author/funder, who has granted medRxiv a license to display the preprint in perpetuity.

\section{It is made available under a CC-BY-NC-ND 4.0 International license .}
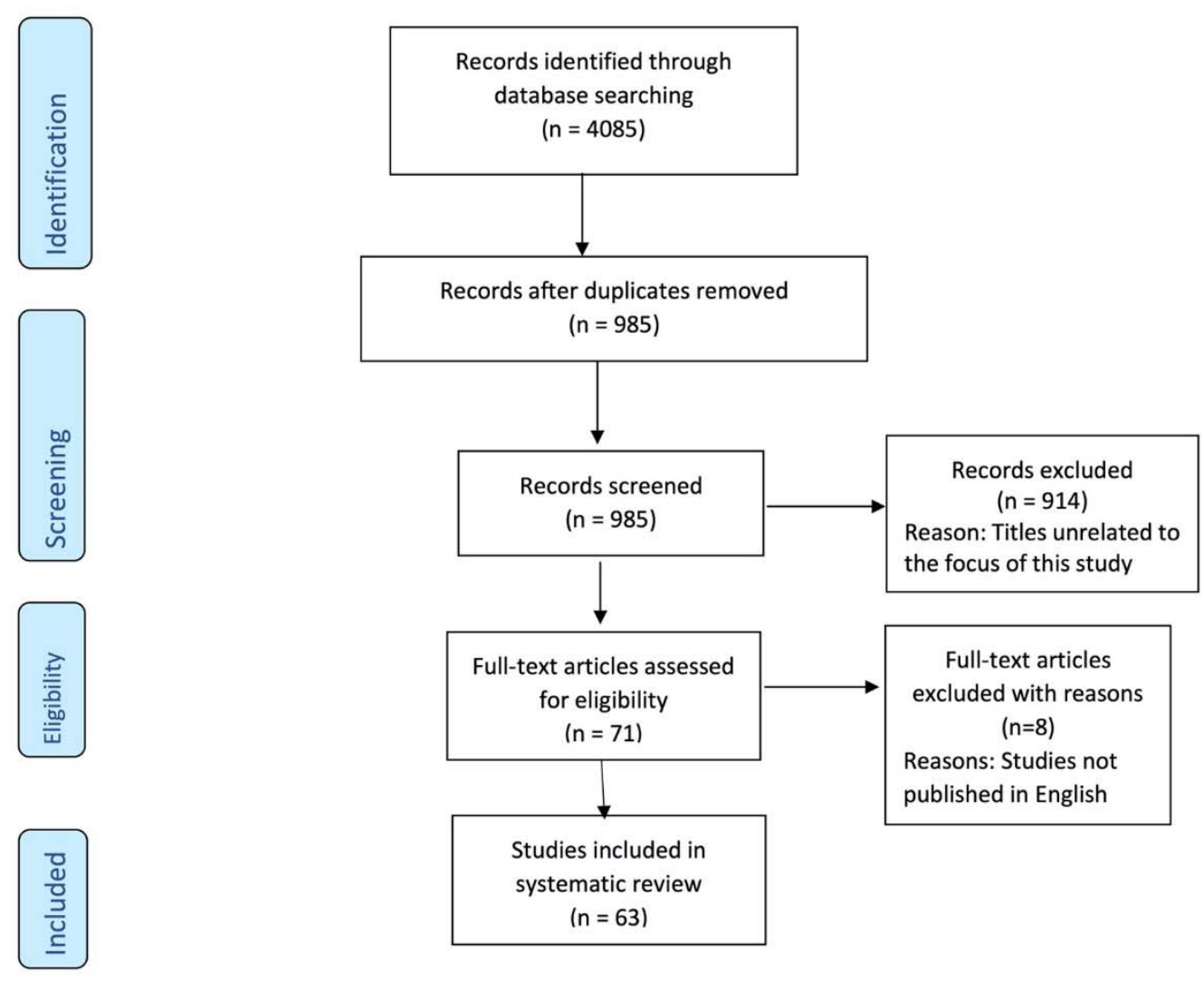

Figure 1: Prisma Diagram for the Selection Process 
medRxiv preprint doi: https://doi.org/10.1101/2021.04.27.21255462; this version posted April 29, 2021. The copyright holder for this preprint (which was not certified by peer review) is the author/funder, who has granted medRxiv a license to display the preprint in perpetuity.

It is made available under a CC-BY-NC-ND 4.0 International license .

Table 1: Search terms

\begin{tabular}{|c|c|}
\hline Constructs & Search terms \\
\hline Obesity & $\begin{array}{l}\text { obesity OR bmi OR "body mass index" OR overweight OR "weight gain" OR "body } \\
\text { weight changes" }\end{array}$ \\
\hline Determinants & determinan* OR facto* OR correlat* OR contributors \\
\hline Setting* & $\begin{array}{l}\text { Africa OR Algeria OR Angola OR Benin OR Botswana OR "Burkina Faso" OR } \\
\text { Burundi OR Cameroon OR "Cape Verde" OR "Central African Republic" OR Chad } \\
\text { OR Comoros OR Congo OR "Congo Democratic Republic" OR drc OR "Côte } \\
\text { d'Ivoire" OR Djibouti OR "Equatorial Guinea" OR Eritrea OR Ethiopia OR Egypt } \\
\text { OR Gabon OR Gambia OR Ghana OR Guinea OR Guinea-Bissau OR Kenya OR } \\
\text { Lesotho OR Libya OR Liberia OR Madagascar OR Morocco OR Malawi OR Mali } \\
\text { OR Mauritania OR Mauritius OR Mozambique OR Namibia OR Niger OR } \\
\text { Nigeria OR Réunion OR Rwanda OR "Sao Tome and Principe" OR Senegal OR } \\
\text { Seychelles OR "Sierra Leone" OR Somalia OR "South Africa" OR Sudan OR } \\
\text { Swaziland OR Tanzania OR Tunisia OR Togo OR Uganda OR "Western Sahara" } \\
\text { OR Zambia OR Zimbabwe }\end{array}$ \\
\hline
\end{tabular}

* These terms purposively had a broader coverage in order to get an overarching picture of the literature space prior to focusing on West Africa. These search terms were entered differently in each database, per database requirements.

Table 2: Number of studies that met the AHRQ checklists 
1) Define the source of information (survey, record $61(97)$

review)

2) List inclusion and exclusion criteria for exposed and

unexposed subjects (cases and controls) or refer to

previous publications

3) Indicate time period used for identifying patients

4) Indicate whether or not subjects were consecutive if

not population-based

5) Indicate if evaluators of subjective components of

study were masked to other aspects of the status of the

participants

6) Describe any assessments undertaken for quality

assurance purposes (e.g., test/retest of primary outcome

measurements)

7) Explain any patient exclusions from analysis

8) Describe how confounding was assessed and/or

controlled.

9) If applicable, explain how missing data were handled

in the analysis

10) Summarize patient response rates and completeness

of data collection

11) Clarify what follow-up, if any, was expected and the percentage of patients for which incomplete data or 
medRxiv preprint doi: https://doi.org/10.1101/2021.04.27.21255462; this version posted April 29, 2021. The copyright holder for this preprint (which was not certified by peer review) is the author/funder, who has granted medRxiv a license to display the preprint in perpetuity.

It is made available under a CC-BY-NC-ND 4.0 International license.

AHRQ Checklists

Number/proportion (\%) of studies that met it

follow-up was obtained 
Table 3: Basic characteristics of the sixty-three included studies

\begin{tabular}{|c|c|c|c|c|c|c|}
\hline Author (year) & Aim & Study setting & $\begin{array}{l}\text { Study } \\
\text { design }\end{array}$ & $\begin{array}{l}\text { Sample } \\
\text { size }\end{array}$ & Sample characteristics & $\begin{array}{l}\text { Primary analysis } \\
\text { /Model(s) used }\end{array}$ \\
\hline Abdula (2010) & $\begin{array}{l}\text { To explore the } \\
\text { determinants of } \\
\text { overweight and obesity } \\
\text { in mothers and children } \\
\text { in Ghana }\end{array}$ & Ghana & $\mathrm{C}$ & $\begin{array}{l}576 \\
\text { househ } \\
\text { olds }\end{array}$ & Males and females $\geq 3$ years & Logistic regression \\
\hline $\begin{array}{l}\text { Addo et al. } \\
\text { (2015) }\end{array}$ & $\begin{array}{l}\text { To determine the } \\
\text { prevalence of obesity } \\
\text { and overweight and } \\
\text { associated factors } \\
\text { among workers of a } \\
\text { financial institution in } \\
\text { Accra Metropolis. }\end{array}$ & Ghana & $\mathrm{C}$ & 180 & $\begin{array}{l}\geq 18 \text { years employees from selected financial } \\
\text { institutions in Ghana }\end{array}$ & Logistic regression \\
\hline Addo \& Leon & To investigate the & Ghana & $\mathrm{C}$ & 1,015 & 615 men and 400 women aged 25 years and & Logistic regression \\
\hline
\end{tabular}




\begin{tabular}{|c|c|c|c|c|c|c|}
\hline Author (year) & Aim & Study setting & $\begin{array}{l}\text { Study } \\
\text { design }\end{array}$ & $\begin{array}{l}\text { Sample } \\
\text { size }\end{array}$ & Sample characteristics & $\begin{array}{l}\text { Primary analysis } \\
\text { /Model(s) used }\end{array}$ \\
\hline (2009) & $\begin{array}{l}\text { distribution of obesity } \\
\text { and its association with } \\
\text { pre-adult wealth and } \\
\text { adult socio-economic } \\
\text { factors in urban } \\
\text { Ghanaian civil servants. }\end{array}$ & & & & $\begin{array}{l}\text { above and employed in government ministries } \\
\text { and departments in Accra }\end{array}$ & \\
\hline $\begin{array}{l}\text { Ajayi et al. } \\
\text { (2016) }\end{array}$ & $\begin{array}{l}\text { To show the collective } \\
\text { burden of obesity and } \\
\text { overweight in sub- } \\
\text { Saharan Africa. }\end{array}$ & $\begin{array}{l}\text { Nigeria South } \\
\text { Africa } \\
\text { Tanzania } \\
\text { Uganda }\end{array}$ & $\mathrm{C}$ & 1463 & $\begin{array}{l}\text { Participants were } 200 \text { nurses from Nigeria, } 489 \\
\text { schoolteachers in South Africa, } 276 \text { teachers in } \\
\text { Tanzania, } 298 \text { village residents in peri-urban } \\
\text { and } 200 \text { rural location in Uganda. They were } \\
\text { both males and females and aged from } 18 \\
\text { years and above. }\end{array}$ & $\begin{array}{l}\text { Binary logistic } \\
\text { regression } \\
\text { Chi square } \\
\text { goodness of fit } \\
\text { test }\end{array}$ \\
\hline $\begin{array}{l}\text { Akarolo- } \\
\text { Anthony et al. } \\
\text { (2014) }\end{array}$ & $\begin{array}{l}\text { To examine the } \\
\text { correlates of obesity }\end{array}$ & Nigeria & $\mathrm{C}$ & 1058 & $\begin{array}{l}\text { males and females, aged } \geq 18 \text { and recruited } \\
\text { from a government worksite at the Federal } \\
\text { Secretariat Complex in Abuja }\end{array}$ & $\begin{array}{l}\text { Log-binomial } \\
\text { regression } \\
\text { analyses }\end{array}$ \\
\hline
\end{tabular}




\begin{tabular}{|c|c|c|c|c|c|c|}
\hline Author (year) & Aim & Study setting & $\begin{array}{l}\text { Study } \\
\text { design }\end{array}$ & $\begin{array}{l}\text { Sample } \\
\text { size }\end{array}$ & Sample characteristics & $\begin{array}{l}\text { Primary analysis } \\
\text { /Model(s) used }\end{array}$ \\
\hline $\begin{array}{l}\text { Akinyeniju et } \\
\text { al. (2016) }\end{array}$ & $\begin{array}{l}\text { To examine the } \\
\text { association between } \\
\text { socio-economic status } \\
\text { (SES) and obesity in } \\
\text { Ghana }\end{array}$ & Ghana & C & 2341 & $\begin{array}{l}\text { Sample included women aged } \geq 18 \text { years } \\
\text { surveyed as part of the Ghana SAGE study. }\end{array}$ & \\
\hline $\begin{array}{l}\text { Aladeniyi et al. } \\
\text { (2017) }\end{array}$ & $\begin{array}{l}\text { To determine the } \\
\text { correlates of obesity } \\
\text { among public service } \\
\text { workers in Akure }\end{array}$ & Nigeria & $\mathrm{C}$ & 4,828 & $\begin{array}{l}\text { Sample included both males and females from } \\
\text { Ondo, but the females were thrice the number } \\
\text { of males. Their ages were from } \geq 18 \text {. }\end{array}$ & Logistic regression \\
\hline $\begin{array}{l}\text { Engle-Stone et } \\
\text { al. (2018) }\end{array}$ & $\begin{array}{l}\text { T examine associations } \\
\text { between household and } \\
\text { individual characteristics } \\
\text { and overweight and } \\
\text { obesity }\end{array}$ & Cameroon & $\mathrm{C}$ & 1,251 & $\begin{array}{l}\text { Sample included only women. Pregnant women } \\
\text { were exempted from the study }\end{array}$ & Logistic regression \\
\hline
\end{tabular}




\begin{tabular}{|c|c|c|c|c|c|c|}
\hline Author (year) & Aim & Study setting & $\begin{array}{l}\text { Study } \\
\text { design }\end{array}$ & $\begin{array}{l}\text { Sample } \\
\text { size }\end{array}$ & Sample characteristics & $\begin{array}{l}\text { Primary analysis } \\
\text { /Model(s) used }\end{array}$ \\
\hline $\begin{array}{l}\text { Atuahene et al. } \\
\text { (2017) }\end{array}$ & $\begin{array}{l}\text { To estimate } \\
\text { overweight/obesity, } \\
\text { hypertension and } \\
\text { diabetes prevalence and } \\
\text { associated risk factors } \\
\text { among public servants. }\end{array}$ & Ghana & $\mathrm{C}$ & 257 & $\begin{array}{l}\text { Sample included males and females, age } 20 \text { to } \\
59 \text { years and from Nadowli district of Ghana. } \\
\text { Their religion was Christianity and Islamic. }\end{array}$ & Logistic regression \\
\hline $\begin{array}{l}\text { Becquey et al. } \\
(2010)\end{array}$ & $\begin{array}{l}\text { To describe dietary } \\
\text { patterns of adults in } \\
\text { Ouagadougou and to } \\
\text { study their relationship } \\
\text { with anthropometric } \\
\text { status of the subjects. }\end{array}$ & Nigeria & $\mathrm{C}$ & 1,072 & $\begin{array}{l}\text { Individuals aged 15-65 years: } 276 \text { women and } \\
261 \text { men from Wemtenga (structured district) } \\
\text { and } 281 \text { women and } 254 \text { men from Taabtenga } \\
\text { (unstructured district) }\end{array}$ & $\begin{array}{l}\text { Multiple linear } \\
\text { regression and } \\
\text { logistic regression }\end{array}$ \\
\hline $\begin{array}{l}\text { Ghose B. \& } \\
\text { Yaya S. (2018) }\end{array}$ & $\begin{array}{l}\text { To investigate the time } \\
\text { trends in body mass } \\
\text { index (BMI) and }\end{array}$ & Nigeria & $\mathrm{C}$ & 69,401 & $\begin{array}{l}\text { Adult non-pregnant women aged between } 15 \\
\text { and } 49 \text { years. }\end{array}$ & $\begin{array}{l}\text { Multinomial } \\
\text { logistic regression }\end{array}$ \\
\hline
\end{tabular}




\begin{tabular}{|c|c|c|c|c|c|c|}
\hline Author (year) & Aim & Study setting & $\begin{array}{l}\text { Study } \\
\text { design }\end{array}$ & $\begin{array}{l}\text { Sample } \\
\text { size }\end{array}$ & Sample characteristics & $\begin{array}{l}\text { Primary analysis } \\
\text { /Model(s) used }\end{array}$ \\
\hline & $\begin{array}{l}\text { relationship between } \\
\text { media use and body } \\
\text { weight status among } \\
\text { adult women in Nigeria. }\end{array}$ & & & & & \\
\hline $\begin{array}{l}\text { Blankson \& Hall } \\
\text { (2010) }\end{array}$ & $\begin{array}{l}\text { To describe the } \\
\text { anthropometric and } \\
\text { physical status of a } \\
\text { sample of elderly } \\
\text { women in rural Ghana } \\
\text { and examine factors } \\
\text { associated with low } \\
\text { BMI. }\end{array}$ & Ghana & $\mathrm{C}$ & 59 & $\begin{array}{l}\text { Elderly women from } 115 \text { households in two } \\
\text { identified villages in Ghana }\end{array}$ & Linear regression \\
\hline $\begin{array}{l}\text { Boua et al. } \\
(2018)\end{array}$ & $\begin{array}{l}\text { To investigate the } \\
\text { distribution of BMI and } \\
\text { prevalence of obesity, }\end{array}$ & Burkina-Faso & $\mathrm{C}$ & 2,706 & $\begin{array}{l}\text { Sample included males and females aged from } \\
40 \text { to } 60 \text { years. }\end{array}$ & $\begin{array}{l}\text { Multivariate } \\
\text { hierarchical } \\
\text { regression }\end{array}$ \\
\hline
\end{tabular}




\begin{tabular}{|c|c|c|c|c|c|c|}
\hline Author (year) & Aim & Study setting & $\begin{array}{l}\text { Study } \\
\text { design }\end{array}$ & $\begin{array}{l}\text { Sample } \\
\text { size }\end{array}$ & Sample characteristics & $\begin{array}{l}\text { Primary analysis } \\
\text { /Model(s) used }\end{array}$ \\
\hline & $\begin{array}{l}\text { and to determine the } \\
\text { socio-demographic and } \\
\text { behavioural correlates } \\
\text { with BMI }\end{array}$ & & & & & analysis \\
\hline $\begin{array}{l}\text { Chigbu et al. } \\
\text { (2018) }\end{array}$ & $\begin{array}{l}\text { To explore the } \\
\text { prevalence and factors } \\
\text { associated with obesity } \\
\text { in Enugu state, Nigeria. }\end{array}$ & Nigeria & $\mathrm{C}$ & 6,459 & $\begin{array}{l}\text { Male and female adults aged } 20-60 \text { years } \\
\text { form both urban and rural setting in Enugu. }\end{array}$ & $\begin{array}{l}\text { Multinomial } \\
\text { regression } \\
\text { analysis }\end{array}$ \\
\hline $\begin{array}{l}\text { Chukwuonye et } \\
\text { al. (2013) }\end{array}$ & $\begin{array}{l}\text { To investigate the } \\
\text { prevalence of } \\
\text { abdominal obesity in } \\
\text { Abia State, Nigeria. }\end{array}$ & Nigeria & $\mathrm{C}$ & 2,807 & $\begin{array}{l}\text { The mean age of the men was } 41.6 \pm 18.8 \\
\text { years, while the mean age of the women was } \\
42.3 \pm 18.5 \text { years. }\end{array}$ & $\begin{array}{l}\text { logistic regression } \\
\text { analysis }\end{array}$ \\
\hline $\begin{array}{l}\text { Cohen et al. } \\
\text { (2018) }\end{array}$ & $\begin{array}{l}\text { To determine the } \\
\text { impact of bio-cultural } \\
\text { factors on the }\end{array}$ & Senegal & C & 597 & $\begin{array}{l}\text { Sample comprised } 393 \text { adults from the } \\
\text { agglomeration of Dakar and } 204 \text { adults from } \\
\text { the rural Kaolack region. }\end{array}$ & $\begin{array}{l}\text { Binary logistic } \\
\text { regression }\end{array}$ \\
\hline
\end{tabular}




\begin{tabular}{|c|c|c|c|c|c|c|}
\hline Author (year) & Aim & Study setting & $\begin{array}{l}\text { Study } \\
\text { design }\end{array}$ & $\begin{array}{l}\text { Sample } \\
\text { size }\end{array}$ & Sample characteristics & $\begin{array}{l}\text { Primary analysis } \\
\text { /Model(s) used }\end{array}$ \\
\hline & $\begin{array}{l}\text { nutritional status of } \\
\text { Senegalese adults. }\end{array}$ & & & & & \\
\hline $\begin{array}{l}\text { Corsi et al. } \\
\text { (2010) }\end{array}$ & $\begin{array}{l}\text { To explore the extent to } \\
\text { which body mass index } \\
\text { (BMI) varies between } \\
\text { small areas or } \\
\text { neighbourhoods in low- } \\
\text { to middle-income } \\
\text { countries }\end{array}$ & $\begin{array}{l}\text { Benin } \\
\text { Burkina Faso } \\
\text { Ghana } \\
\text { Guinea } \\
\text { Liberia Niger } \\
\text { Togo Senegal } \\
\text { Mali Sierra } \\
\text { Leone, } \\
\text { Cameroon } \\
\text { Ivory Coast } \\
\text { Nigeria } \\
\text { Gabon }\end{array}$ & $\mathrm{C}$ & 451,321 & $\begin{array}{l}\text { Sample included non-pregnant women aged } \\
\text { from } 20 \text { to } 49 \text { years both with or without } \\
\text { children from participating countries. }\end{array}$ & Multilevel analysis \\
\hline
\end{tabular}




\begin{tabular}{|c|c|c|c|c|c|c|}
\hline Author (year) & Aim & Study setting & $\begin{array}{l}\text { Study } \\
\text { design }\end{array}$ & $\begin{array}{l}\text { Sample } \\
\text { size }\end{array}$ & Sample characteristics & $\begin{array}{l}\text { Primary analysis } \\
\text { /Model(s) used }\end{array}$ \\
\hline $\begin{array}{l}\text { Dake et al. } \\
\text { (2011) }\end{array}$ & $\begin{array}{l}\text { To examine the } \\
\text { sociodemographic } \\
\text { correlates of obesity } \\
\text { among Ghanaian } \\
\text { women }\end{array}$ & Ghana & $\mathrm{C}$ & 5,279 & $\begin{array}{l}\text { Sample included only women aged from } 15 \text { to } \\
49 \text { years living in any of the ten regions of } \\
\text { Ghana. }\end{array}$ & $\begin{array}{l}\text { Multinomial } \\
\text { logistic regression }\end{array}$ \\
\hline $\begin{array}{l}\text { Dake et al. } \\
\text { (2016) }\end{array}$ & $\begin{array}{l}\text { To examine the } \\
\text { characteristics of the } \\
\text { local food environment } \\
\text { in an urban poor setting } \\
\text { in Accra and the } \\
\text { associated risk of } \\
\text { obesity for residents }\end{array}$ & Ghana & $\mathrm{C}$ & 657 & $\begin{array}{l}\text { Sample included males aged from } 15-59 \text { and } \\
\text { females from } 15-49 \text { and residents James } \\
\text { town, Ussher town and Agbobloshie. } \\
\text { Participants had an average of } 25.58 \mathrm{~kg} / \mathrm{m}^{2} \text { and } \\
\text { the females had a higher BMI on the average } \\
\text { than males }\end{array}$ & $\begin{array}{l}\text { Multilevel } \\
\text { analysis, bivariate } \\
\text { ordinary least } \\
\text { squares } \\
\text { regression }\end{array}$ \\
\hline Dake (2012) & $\begin{array}{l}\text { To investigate spatial } \\
\text { autocorrelation in BMI } \\
\text { using the cluster as the }\end{array}$ & Ghana & $\mathrm{C}$ & 4,454 & Only women aged between 15 and 49 years & $\begin{array}{l}\text { Histogram, Box } \\
\text { plots and } \\
\text { Cartogram }\end{array}$ \\
\hline
\end{tabular}




\begin{tabular}{|c|c|c|c|c|c|c|}
\hline Author (year) & Aim & Study setting & $\begin{array}{l}\text { Study } \\
\text { design }\end{array}$ & $\begin{array}{l}\text { Sample } \\
\text { size }\end{array}$ & Sample characteristics & $\begin{array}{l}\text { Primary analysis } \\
\text { /Model(s) used }\end{array}$ \\
\hline & $\begin{array}{l}\text { spatial unit of } \\
\text { observation. }\end{array}$ & & & & & \\
\hline $\begin{array}{l}\text { Damorou et al. } \\
\text { (2013) }\end{array}$ & $\begin{array}{l}\text { To determine the } \\
\text { prevalence of obesity } \\
\text { and its risk factors } \\
\text { among workers in Lomé }\end{array}$ & Togo & $\mathrm{C}$ & 510 & $\begin{array}{l}\text { Male and female workers aged } 18 \text { years and } \\
\text { above in Lomé. }\end{array}$ & linear regression \\
\hline $\begin{array}{l}\text { Dickson et al. } \\
(2016)\end{array}$ & $\begin{array}{l}\text { To assess the } \\
\text { association between } \\
\text { dietary diversity (DD) } \\
\text { score, socioeconomic } \\
\text { status (SES) and } \\
\text { maternal BMI, and the } \\
\text { variation of the effects } \\
\text { of DD and SES at }\end{array}$ & Ghana & $\mathrm{C}$ & 2038 & $\begin{array}{l}\text { Sample included women from } 15-59 \text { years } \\
\text { and their partners from } 15 \text { to } 49 \text { years old. } \\
\text { Sample was from both rural and urban } \\
\text { settlements. }\end{array}$ & $\begin{array}{l}\text { Quantile } \\
\text { regression } \\
\text { analysis }\end{array}$ \\
\hline
\end{tabular}




\begin{tabular}{|c|c|c|c|c|c|c|}
\hline Author (year) & Aim & Study setting & $\begin{array}{l}\text { Study } \\
\text { design }\end{array}$ & $\begin{array}{l}\text { Sample } \\
\text { size }\end{array}$ & Sample characteristics & $\begin{array}{l}\text { Primary analysis } \\
\text { /Model(s) used }\end{array}$ \\
\hline & $\begin{array}{l}\text { different points of the } \\
\text { conditional distribution } \\
\text { of the BMI. }\end{array}$ & & & & & \\
\hline $\begin{array}{l}\text { Diendéré et al. } \\
\text { (2019) }\end{array}$ & $\begin{array}{l}\text { To determine the } \\
\text { prevalence and factors } \\
\text { associated with } \\
\text { overweight/obesity } \\
\text { among women living in } \\
\text { rural and urban Burkina } \\
\text { Faso }\end{array}$ & Burkina Faso & $\mathrm{C}$ & 2191 & $\begin{array}{l}\text { Women aged from } \geq 25 \text { years from selected } \\
\text { rural and urban areas }\end{array}$ & $\begin{array}{l}\text { Multivariate } \\
\text { logistic regression }\end{array}$ \\
\hline $\begin{array}{l}\text { Doku \& } \\
\text { Neupane } \\
\text { (2015) }\end{array}$ & $\begin{array}{l}\text { To explore trends in } \\
\text { overweight/obesity and } \\
\text { underweight and } \\
\text { associated factors were }\end{array}$ & Ghana & $\mathrm{C}$ & 20,012 & $\begin{array}{l}\text { Women aged from } 15 \text { to } 49 \text { years from four } \\
\text { demographic and health surveys conducted in } \\
\text { Ghana; } 1993,1998,2003 \text { and } 2008\end{array}$ & $\begin{array}{l}\text { Multinomial } \\
\text { logistic regression }\end{array}$ \\
\hline
\end{tabular}




\begin{tabular}{|c|c|c|c|c|c|c|}
\hline Author (year) & Aim & Study setting & $\begin{array}{l}\text { Study } \\
\text { design }\end{array}$ & $\begin{array}{l}\text { Sample } \\
\text { size }\end{array}$ & Sample characteristics & $\begin{array}{l}\text { Primary analysis } \\
\text { /Model(s) used }\end{array}$ \\
\hline & $\begin{array}{l}\text { explored among } 15 \text { to } \\
49 \text { years old women in } \\
\text { Ghana. }\end{array}$ & & & & & \\
\hline $\begin{array}{l}\text { Maruf \& Udoji } \\
\text { (2015) }\end{array}$ & $\begin{array}{l}\text { To explore prevalence of } \\
\text { overweight and obesity } \\
\text { and their associations } \\
\text { with socio demographic } \\
\text { variables in a Nigerian } \\
\text { population. }\end{array}$ & Nigeria & $\mathrm{C}$ & 1,521 & Male and females aged 18 years and above & $\begin{array}{l}\text { Multinomial } \\
\text { logistic regression }\end{array}$ \\
\hline $\begin{array}{l}\text { Fezeu at al. } \\
(2005)\end{array}$ & $\begin{array}{l}\text { To determine the } \\
\text { association between } \\
\text { socio-economic status } \\
\text { and adiposity in urban } \\
\text { Cameroon }\end{array}$ & Cameroon & $\mathrm{C}$ & 2,831 & $\begin{array}{l}\text { Samples were recruited from Biyem-Assi, an } \\
\text { urban area of Yaoundé, the capital city of } \\
\text { Cameroon. The participants included civil } \\
\text { servants, businessmen, and students aged } 25 \\
\text { years and over. }\end{array}$ & $\begin{array}{l}\text { Logistic regression } \\
\text { model Logistic } \\
\text { regression model }\end{array}$ \\
\hline Fezeu et al. & To compare the 10 -year & Cameroon & $\mathrm{C}$ & 3,160 & & Multivariate \\
\hline
\end{tabular}




\begin{tabular}{|c|c|c|c|c|c|c|}
\hline Author (year) & Aim & Study setting & $\begin{array}{l}\text { Study } \\
\text { design }\end{array}$ & $\begin{array}{l}\text { Sample } \\
\text { size }\end{array}$ & Sample characteristics & $\begin{array}{l}\text { Primary analysis } \\
\text { /Model(s) used }\end{array}$ \\
\hline (2008) & $\begin{array}{l}\text { changes in the } \\
\text { distribution of adiposity } \\
\text { in rural and urban } \\
\text { Cameroonian } \\
\text { populations }\end{array}$ & & & & & $\begin{array}{l}\text { logistic regression } \\
\text { models }\end{array}$ \\
\hline $\begin{array}{l}\text { Goryakin et al. } \\
(2015)\end{array}$ & $\begin{array}{l}\text { To assess the impact of } \\
\text { globalization on } \\
\text { overweight and obesity } \\
\text { on } 56 \text { selected countries }\end{array}$ & $\begin{array}{l}\text { Ghana Gabon } \\
\text { Benin } \\
\text { Burkina Faso } \\
\text { Cameroon } \\
\text { Cote d'Ivoire } \\
\text { Guinea }\end{array}$ & $\mathrm{C}$ & $\begin{array}{l}1,225,8 \\
16\end{array}$ & $\begin{array}{l}\text { Sample included only women from } 15 \text { to } 49 \\
\text { years in some selected low- and middle-income } \\
\text { countries. }\end{array}$ & $\begin{array}{l}\text { Ordinary least } \\
\text { squares (OLS) }\end{array}$ \\
\hline $\begin{array}{l}\text { Grey et al. } \\
(2006)\end{array}$ & $\begin{array}{l}\text { To investigate the } \\
\text { distribution of } \\
\text { overweight and obesity } \\
\text { and its relationship with }\end{array}$ & Gambia & $\mathrm{C}$ & 200 & $\begin{array}{l}\text { The subjects were divided by gender (male- } \\
\text { female) and by age ( } 14-25 \text { and } 35-50 \text { years). } \\
\text { Each group I made up of } 50 \text { respondents }\end{array}$ & Chi Square test \\
\hline
\end{tabular}




\begin{tabular}{|c|c|c|c|c|c|c|}
\hline Author (year) & Aim & Study setting & $\begin{array}{l}\text { Study } \\
\text { design }\end{array}$ & $\begin{array}{l}\text { Sample } \\
\text { size }\end{array}$ & Sample characteristics & $\begin{array}{l}\text { Primary analysis } \\
\text { /Model(s) used }\end{array}$ \\
\hline & $\begin{array}{l}\text { socio-economic and } \\
\text { behavioural factors in a } \\
\text { developing-country } \\
\text { population undergoing } \\
\text { rapid nutritional } \\
\text { transition. }\end{array}$ & & & & & \\
\hline $\begin{array}{l}\text { Koussoh et al. } \\
\text { (2019) }\end{array}$ & $\begin{array}{l}\text { To assess correlates of } \\
\text { overweight and obesity } \\
\text { among women in a sub- } \\
\text { urban population of } \\
\text { Abidjan, Côte d'Ivoire. }\end{array}$ & Côte d'Ivoire. & $\mathrm{C}$ & 327 & $\begin{array}{l}\text { Study involved only women } 15 \text { years old and } \\
\text { above }\end{array}$ & $\begin{array}{l}\text { Logistic regression } \\
\text { model. }\end{array}$ \\
\hline $\begin{array}{l}\text { Lartey et al. } \\
\text { (2019) }\end{array}$ & $\begin{array}{l}\text { To examine recent } \\
\text { changes in obesity } \\
\text { prevalence and } \\
\text { associated factors for }\end{array}$ & Ghana & C & 5,821 & $\begin{array}{l}\text { Sample included adults aged } 50 \text { years and older } \\
\text { in Ghana. They were drawn from the WHO } \\
\text { SAGE 2007/08 (Wave } 1 ; n=4158 \text { ) and } 2014 / 15 \\
\text { (Wave } 2 ; n=1663 \text { ). }\end{array}$ & $\begin{array}{l}\text { Multinomial and } \\
\text { binomial logistic } \\
\text { regression }\end{array}$ \\
\hline
\end{tabular}




\begin{tabular}{|c|c|c|c|c|c|c|}
\hline Author (year) & Aim & Study setting & $\begin{array}{l}\text { Study } \\
\text { design }\end{array}$ & $\begin{array}{l}\text { Sample } \\
\text { size }\end{array}$ & Sample characteristics & $\begin{array}{l}\text { Primary analysis } \\
\text { /Model(s) used }\end{array}$ \\
\hline & $\begin{array}{l}\text { older adults in Ghana } \\
\text { between } 2007 / 08 \text { and } \\
2014 / 15\end{array}$ & & & & & \\
\hline $\begin{array}{l}\text { Luke et al. } \\
\text { (2014) }\end{array}$ & $\begin{array}{l}\text { To examine whether } \\
\text { low levels of PA are } \\
\text { associated with excess } \\
\text { weight and adiposity. }\end{array}$ & Ghana & $\mathrm{C}$ & 500 & $\begin{array}{l}\text { Sample included young male and female adults } \\
\text { aged } 25 \text { to } 45 \text { years }\end{array}$ & $\begin{array}{l}\text { multiple linear } \\
\text { regression }\end{array}$ \\
\hline $\begin{array}{l}\text { Macia et al. } \\
\text { (2010) }\end{array}$ & $\begin{array}{l}\text { To determine } \\
\text { the prevalence of } \\
\text { obesity in Dakar }\end{array}$ & Senegal & $\mathrm{C}$ & 600 & $\begin{array}{l}\text { men and women aged from } 20 \text { years and above } \\
\text { living in the Dakar. }\end{array}$ & Logistic regression \\
\hline $\begin{array}{l}\text { Chidozie et al. } \\
\text { (2009) }\end{array}$ & $\begin{array}{l}\text { To examine } \\
\text { relationships between } \\
\text { SES and BMI, investigate } \\
\text { whether variations in } \\
\text { BMI are influenced by }\end{array}$ & Nigeria & $\mathrm{C}$ & 1,067 & $\begin{array}{l}552 \text { men and } 515 \text { women aged between } 30 \text { and } \\
60 \text { years }\end{array}$ & $\begin{array}{l}\text { Multivariate linear } \\
\text { regression } \\
\text { analysis }\end{array}$ \\
\hline
\end{tabular}




\begin{tabular}{|c|c|c|c|c|c|c|}
\hline Author (year) & Aim & Study setting & $\begin{array}{l}\text { Study } \\
\text { design }\end{array}$ & $\begin{array}{l}\text { Sample } \\
\text { size }\end{array}$ & Sample characteristics & $\begin{array}{l}\text { Primary analysis } \\
\text { /Model(s) used }\end{array}$ \\
\hline & $\begin{array}{l}\text { differences in SES, and } \\
\text { estimate the prevalence } \\
\text { of overweight and } \\
\text { obesity in a semi-urban } \\
\text { population in Nigeria. }\end{array}$ & & & & & \\
\hline $\begin{array}{l}\text { Mogre et al. } \\
\text { (2015) }\end{array}$ & $\begin{array}{l}\text { To investigate the } \\
\text { influence of socio- } \\
\text { demographic, dietary } \\
\text { habits and physical } \\
\text { activity levels on general } \\
\text { and abdominal obesity } \\
\text { among a sample of } \\
\text { university students in } \\
\text { Ghana }\end{array}$ & Ghana & $\mathrm{C}$ & 552 & $\begin{array}{l}\text { Male and female participants aged 18-36 years } \\
\text { attending the University for Development } \\
\text { Studies, School of Medicine and Health } \\
\text { Sciences Tamale, Ghana }\end{array}$ & $\begin{array}{l}\text { Multinomial } \\
\text { logistic regression }\end{array}$ \\
\hline Neupane et al. & To assess the magnitude & Sub-Saharan & $\mathrm{C}$ & 250,651 & Sample included only women from 32 countries & Logistic regression \\
\hline
\end{tabular}




\begin{tabular}{|c|c|c|c|c|c|c|}
\hline Author (year) & Aim & Study setting & $\begin{array}{l}\text { Study } \\
\text { design }\end{array}$ & $\begin{array}{l}\text { Sample } \\
\text { size }\end{array}$ & Sample characteristics & $\begin{array}{l}\text { Primary analysis } \\
\text { /Model(s) used }\end{array}$ \\
\hline (2016) & $\begin{array}{l}\text { and disparity of } \\
\text { overweight and obesity } \\
\text { by residence, level of } \\
\text { education and wealth } \\
\text { quintile using cross- } \\
\text { sectional data from } 32 \\
\text { countries. }\end{array}$ & Africa & & & $\begin{array}{l}\text { in Sub-Saharan Africa. Their mean age was } \\
28.46 \text { years }\end{array}$ & \\
\hline $\begin{array}{l}\text { Ngianga- } \\
\text { Bakwin \& } \\
\text { Saverio (2014) }\end{array}$ & $\begin{array}{l}\text { To examine the } \\
\text { geographic variation of } \\
\text { overweight and obesity } \\
\text { prevalence at the state- } \\
\text { level among women in } \\
\text { Nigeria }\end{array}$ & Nigeria & $\mathrm{C}$ & 27,967 & $\begin{array}{l}\text { Sample included only women aged from } 15- \\
49 \text { years old. }\end{array}$ & $\begin{array}{l}\text { Multivariate } \\
\text { Bayesian geo- } \\
\text { additive } \\
\text { regression models }\end{array}$ \\
\hline $\begin{array}{l}\text { Nonterah et al. } \\
\text { (2017) }\end{array}$ & $\begin{array}{l}\text { The study characterized } \\
\text { the socio-demographic }\end{array}$ & Ghana & $\mathrm{C}$ & 2,014 & $\begin{array}{l}\text { Men and women aged } 40-60 \text { years who had } \\
\text { been resident within the study area for at least }\end{array}$ & $\begin{array}{l}\text { Hierarchical linear } \\
\text { regression }\end{array}$ \\
\hline
\end{tabular}




\begin{tabular}{|c|c|c|c|c|c|c|}
\hline Author (year) & Aim & Study setting & $\begin{array}{l}\text { Study } \\
\text { design }\end{array}$ & $\begin{array}{l}\text { Sample } \\
\text { size }\end{array}$ & Sample characteristics & $\begin{array}{l}\text { Primary analysis } \\
\text { /Model(s) used }\end{array}$ \\
\hline & $\begin{array}{l}\text { and behavioral factors } \\
\text { influencing BMI among } \\
\text { adults in rural Northern } \\
\text { Ghana. }\end{array}$ & & & & 10 years. & analysis \\
\hline $\begin{array}{l}\text { Nuertey et al. } \\
\text { (2017) }\end{array}$ & $\begin{array}{l}\text { To determine the } \\
\text { prevalence of obesity } \\
\text { and overweight and its } \\
\text { associated factors } \\
\text { amongst registered } \\
\text { pensioners in Ghana }\end{array}$ & Ghana & C & 4813 & $\begin{array}{l}\text { Male and female members of the National } \\
\text { pensioners association (NPA) in all the ten } \\
\text { regional capitals in Ghana, aged sixty years and } \\
\text { above. }\end{array}$ & Logistic regression \\
\hline $\begin{array}{l}\text { Chinedu et al. } \\
\text { (2017) }\end{array}$ & $\begin{array}{l}\text { To investigate the body } \\
\text { weight distribution } \\
\text { amongst sexes and } \\
\text { different age groups in } \\
\text { educational institutions }\end{array}$ & Nigeria & $\mathrm{C}$ & 1,394 & $\begin{array}{l}\text { Male and females aged } 2 \text { to } 75 \text { years and from } \\
\text { four educational institutions in, Ota. }\end{array}$ & Logistic regression \\
\hline
\end{tabular}




\begin{tabular}{|c|c|c|c|c|c|c|}
\hline Author (year) & Aim & Study setting & $\begin{array}{l}\text { Study } \\
\text { design }\end{array}$ & $\begin{array}{l}\text { Sample } \\
\text { size }\end{array}$ & Sample characteristics & $\begin{array}{l}\text { Primary analysis } \\
\text { /Model(s) used }\end{array}$ \\
\hline & $\begin{array}{l}\text { in Ota, Southwest } \\
\text { Nigeria. }\end{array}$ & & & & & \\
\hline $\begin{array}{l}\text { Obirikorang et } \\
\text { al. (2016) }\end{array}$ & $\begin{array}{l}\text { To determine the } \\
\text { prevalence and risk } \\
\text { factors of obesity } \\
\text { among practicing nurses } \\
\text { in three selected } \\
\text { hospitals in the Kumasi } \\
\text { metropolis. }\end{array}$ & Ghana & $\mathrm{C}$ & 825 & $\begin{array}{l}\text { Females }(83.9 \%) \text { and males }(16.1 \%) \text { with an } \\
\text { average age of } 31.6 \pm 9.7 \text { years. }\end{array}$ & Logistic regression \\
\hline $\begin{array}{l}\text { Obirikorang et } \\
\text { al. (2015) }\end{array}$ & $\begin{array}{l}\text { To describe differences } \\
\text { in prevalence of obesity } \\
\text { and cardio-metabolic } \\
\text { risk factors between } \\
\text { urban and rural } \\
\text { settlements in the }\end{array}$ & Ghana & $\mathrm{C}$ & 672 & $\begin{array}{l}\text { Male and female participants from the Ashanti } \\
\text { region of Ghana with a median age of } 50 \text { years }\end{array}$ & $\begin{array}{l}\text { Multivariate } \\
\text { logistic regression }\end{array}$ \\
\hline
\end{tabular}




\begin{tabular}{|c|c|c|c|c|c|c|}
\hline Author (year) & Aim & Study setting & $\begin{array}{l}\text { Study } \\
\text { design }\end{array}$ & $\begin{array}{l}\text { Sample } \\
\text { size }\end{array}$ & Sample characteristics & $\begin{array}{l}\text { Primary analysis } \\
\text { /Model(s) used }\end{array}$ \\
\hline & $\begin{array}{l}\text { Ashanti Region of } \\
\text { Ghana. }\end{array}$ & & & & & \\
\hline Okoh (2013) & $\begin{array}{l}\text { To explore the social } \\
\text { and demographic } \\
\text { factors associated with } \\
\text { overweight and obesity } \\
\text { among adult women of } \\
\text { reproductive age in } \\
\text { Nigeria and as such } \\
\text { provide information that } \\
\text { could help identify the } \\
\text { most at-risk group for } \\
\text { targeted intervention. }\end{array}$ & Nigeria & $\mathrm{C}$ & 18,107 & $\begin{array}{l}\text { Women aged } 20 \text { to } 49 \text { were included in the } \\
\text { study }\end{array}$ & $\begin{array}{l}\text { multi-nominal } \\
\text { logistic regression }\end{array}$ \\
\hline Olatunbosun et & To explore the & Nigeria & $\mathrm{C}$ & 998 & Sample included male and female civil servants & logistic regression \\
\hline
\end{tabular}




\begin{tabular}{|c|c|c|c|c|c|c|}
\hline Author (year) & Aim & Study setting & $\begin{array}{l}\text { Study } \\
\text { design }\end{array}$ & $\begin{array}{l}\text { Sample } \\
\text { size }\end{array}$ & Sample characteristics & $\begin{array}{l}\text { Primary analysis } \\
\text { /Model(s) used }\end{array}$ \\
\hline al. (2010) & $\begin{array}{l}\text { prevalence of obesity } \\
\text { and overweight in an } \\
\text { urban setting in Ibadan, } \\
\text { Nigeria. }\end{array}$ & & & & aged from $19-70$ years in Ibadan. & \\
\hline $\begin{array}{l}\text { Ajayi et al. } \\
\text { (2016) }\end{array}$ & $\begin{array}{l}\text { To show the collective } \\
\text { burden of obesity in } \\
\text { sub-Saharan Africa and } \\
\text { to determine the } \\
\text { differences between } \\
\text { urban and rural } \\
\text { populations and other } \\
\text { socioeconomic factors. }\end{array}$ & $\begin{array}{l}\text { Nigeria } \\
\text { South Africa } \\
\text { Tanzania } \\
\text { Uganda }\end{array}$ & $\mathrm{C}$ & 1,463 & $\begin{array}{l}\text { Participants included nurses in two hospitals in } \\
\text { Nigeria, school teachers in South Africa and } \\
\text { Tanzania, and village residents in one peri- } \\
\text { urban and one rural location in Uganda. They } \\
\text { aged 18-80years }\end{array}$ & $\begin{array}{l}\text { Binary logistic } \\
\text { regression }\end{array}$ \\
\hline $\begin{array}{l}\text { Osayomi \& } \\
\text { Orhiere (2017) }\end{array}$ & $\begin{array}{l}\text { To determine the small- } \\
\text { area variations in the } \\
\text { prevalence of }\end{array}$ & Nigeria & $\mathrm{C}$ & 234 & $\begin{array}{l}\text { Sample included male and females from Ibadan } \\
\text { North LGA, Nigeria aged from } 18 \text { years and } \\
\text { above. }\end{array}$ & $\begin{array}{l}\text { Simple linear } \\
\text { regression }\end{array}$ \\
\hline
\end{tabular}




\begin{tabular}{|c|c|c|c|c|c|c|}
\hline Author (year) & Aim & Study setting & $\begin{array}{l}\text { Study } \\
\text { design }\end{array}$ & $\begin{array}{l}\text { Sample } \\
\text { size }\end{array}$ & Sample characteristics & $\begin{array}{l}\text { Primary analysis } \\
\text { /Model(s) used }\end{array}$ \\
\hline & $\begin{array}{l}\text { overweight and obesity } \\
\text { in an urban area of } \\
\text { Nigeria and its } \\
\text { association with socio- } \\
\text { economic, } \\
\text { environmental, dietary } \\
\text { and lifestyle risk factors. }\end{array}$ & & & & & \\
\hline $\begin{array}{l}\text { Oue'draogo et } \\
\text { al. (2008) }\end{array}$ & $\begin{array}{l}\text { To document the } \\
\text { prevalence and the } \\
\text { socio-spatial variations } \\
\text { of obesity and to } \\
\text { identify individual and } \\
\text { household } \\
\text { characteristics, lifestyles } \\
\text { and dietary practices }\end{array}$ & Burkina Faso & $\mathrm{C}$ & 2022 & $\begin{array}{l}\text { Male and females aged from } 35 \text { years and } \\
\text { above }\end{array}$ & Chi-square \\
\hline
\end{tabular}




\begin{tabular}{|c|c|c|c|c|c|c|}
\hline Author (year) & Aim & Study setting & $\begin{array}{l}\text { Study } \\
\text { design }\end{array}$ & $\begin{array}{l}\text { Sample } \\
\text { size }\end{array}$ & Sample characteristics & $\begin{array}{l}\text { Primary analysis } \\
\text { /Model(s) used }\end{array}$ \\
\hline & $\begin{array}{l}\text { contributing to obesity } \\
\text { and its socio-spatial } \\
\text { distribution. }\end{array}$ & & & & & \\
\hline $\begin{array}{l}\text { Oyebisi \& } \\
\text { Olumakaiye ( }\end{array}$ & $\begin{array}{l}\text { To assess fast food } \\
\text { consumption pattern } \\
\text { and body weight status } \\
\text { among the } \\
\text { undergraduates of } \\
\text { Obafemi Awolowo } \\
\text { University, Ile-Ife, } \\
\text { Nigeria }\end{array}$ & Nigeria & $\mathrm{C}$ & 360 & $\begin{array}{l}\text { Sample included male and female students } \\
\text { aged below } 18 \text { years and above from the } \\
\text { Obafemi Awolowo University, Ile-Ife, Nigeria } \\
\text { during the rain semester in } 2011 / 2012 \text { session }\end{array}$ & $\begin{array}{l}\text { Regression } \\
\text { analysis }\end{array}$ \\
\hline $\begin{array}{l}\text { Oyeyemi et al. } \\
\text { (2013) }\end{array}$ & $\begin{array}{l}\text { To investigate the } \\
\text { mediating effects of PA } \\
\text { and sedentary time on }\end{array}$ & Nigeria & $\mathrm{C}$ & 1,411 & $\begin{array}{l}\text { The sample consisted of } 43.1 \% \text { women and } \\
56.9 \% \text { men from Nigeria }\end{array}$ & $\begin{array}{l}\text { Generalized Linear } \\
\text { Models }\end{array}$ \\
\hline
\end{tabular}




\begin{tabular}{|c|c|c|c|c|c|c|}
\hline Author (year) & Aim & Study setting & $\begin{array}{l}\text { Study } \\
\text { design }\end{array}$ & $\begin{array}{l}\text { Sample } \\
\text { size }\end{array}$ & Sample characteristics & $\begin{array}{l}\text { Primary analysis } \\
\text { /Model(s) used }\end{array}$ \\
\hline & $\begin{array}{l}\text { the associations of } \\
\text { neighbourhood } \\
\text { environmental factors } \\
\text { and body mass index } \\
\text { (BMI) among Nigerian } \\
\text { adults. }\end{array}$ & & & & & \\
\hline $\begin{array}{l}\text { Oyeyemi \& } \\
\text { Adegoke } \\
(2012)\end{array}$ & $\begin{array}{l}\text { To examine associations } \\
\text { between } \\
\text { neighbourhood } \\
\text { environment variables } \\
\text { and overweight in } \\
\text { Nigeria adults. }\end{array}$ & Nigeria & $\mathrm{C}$ & 1818 & $\begin{array}{l}\text { Samples included males and females from age } \\
25 \text { to } 65 \text { years systematically recruited from } 38 \\
\text { neighbourhoods categorized into in Maiduguri, } \\
\text { Nigeria. }\end{array}$ & $\begin{array}{l}\text { Logistic regression } \\
\text { analysis }\end{array}$ \\
\hline $\begin{array}{l}\text { Pasquet et al. } \\
\text { (2003) }\end{array}$ & $\begin{array}{l}\text { To examine the current } \\
\text { prevalence of }\end{array}$ & Cameroon & $\mathrm{C}$ & 771 & $\begin{array}{l}\text { Sample included all men and women } 20 \text { years } \\
\text { and above. Pregnant and lactating mothers }\end{array}$ & $\begin{array}{l}\text { Logistic regression } \\
\text { model }\end{array}$ \\
\hline
\end{tabular}




\begin{tabular}{|c|c|c|c|c|c|c|}
\hline Author (year) & Aim & Study setting & $\begin{array}{l}\text { Study } \\
\text { design }\end{array}$ & $\begin{array}{l}\text { Sample } \\
\text { size }\end{array}$ & Sample characteristics & $\begin{array}{l}\text { Primary analysis } \\
\text { /Model(s) used }\end{array}$ \\
\hline & $\begin{array}{l}\text { overweight and obesity } \\
\text { in Yaoundé, the capital } \\
\text { city of Cameroon and } \\
\text { search for possible } \\
\text { causal factors }\end{array}$ & & & & were excluded from sample. & \\
\hline $\begin{array}{l}\text { Peltzer et al. } \\
(2014)\end{array}$ & $\begin{array}{l}\text { To determine the } \\
\text { prevalence of } \\
\text { overweight/obesity and } \\
\text { its associated factors } \\
\text { among University } \\
\text { students in } 22 \text { low- and } \\
\text { middle-income } \\
\text { countries and emerging } \\
\text { economy countries }\end{array}$ & $\begin{array}{l}\text { Ivory Coast } \\
\text { Nigeria }\end{array}$ & $\mathrm{C}$ & 835 & $\begin{array}{l}\text { Samples were selected from } 22 \text { universities. } \\
\text { They were aged from } 16 \text { to } 30 \text { and above. } \\
\text { Participants were both males and females. }\end{array}$ & $\begin{array}{l}\text { Multivariate } \\
\text { logistic regression }\end{array}$ \\
\hline Ramsay et al. & To compare regional & Ghana & $\mathrm{C}$ & 1,968 & The sample included male and female adult & Multiple linear \\
\hline
\end{tabular}




\begin{tabular}{|c|c|c|c|c|c|c|}
\hline Author (year) & Aim & Study setting & $\begin{array}{l}\text { Study } \\
\text { design }\end{array}$ & $\begin{array}{l}\text { Sample } \\
\text { size }\end{array}$ & Sample characteristics & $\begin{array}{l}\text { Primary analysis } \\
\text { /Model(s) used }\end{array}$ \\
\hline (2009) & $\begin{array}{l}\text { and sex-specific body } \\
\text { mass index (BMI) } \\
\text { distributions, using a } \\
\text { cross-sectional study } \\
\text { design, in adults aged } \\
40-60 \text { years across six } \\
\text { study sites in four sub- } \\
\text { Saharan African (SSA) } \\
\text { countries and to } \\
\text { compare the } \\
\text { determinants of BMI at } \\
\text { each. }\end{array}$ & Burkina Faso & & & $\begin{array}{l}\text { population aged } 40-60 \text { years from Navrongo } \\
\text { in Ghana and Nanoro in Burkina Faso. }\end{array}$ & $\begin{array}{l}\text { regression (Sex- } \\
\text { stratified } \\
\text { hierarchical } \\
\text { models) }\end{array}$ \\
\hline $\begin{array}{l}\text { Razak et al. } \\
\text { (2015) }\end{array}$ & $\begin{array}{l}\text { To determine the } \\
\text { prevalence and } \\
\text { distribution of BMI }\end{array}$ & $\begin{array}{l}\text { LMICs } \\
\text { including } \\
\text { west african }\end{array}$ & $\mathrm{C}$ & 7,948 & Women aged from 20 to 49 years & Logistic regression \\
\hline
\end{tabular}




\begin{tabular}{|c|c|c|c|c|c|c|}
\hline Author (year) & Aim & Study setting & $\begin{array}{l}\text { Study } \\
\text { design }\end{array}$ & $\begin{array}{l}\text { Sample } \\
\text { size }\end{array}$ & Sample characteristics & $\begin{array}{l}\text { Primary analysis } \\
\text { /Model(s) used }\end{array}$ \\
\hline & $\begin{array}{l}\text { lower than } 16 \text { and its } \\
\text { change in prevalence } \\
\text { over time in women in } \\
\text { LMIC. }\end{array}$ & countries & & & & \\
\hline $\begin{array}{l}\text { Smith et al. } \\
\text { (2017) }\end{array}$ & $\begin{array}{l}\text { To determine the } \\
\text { association between } \\
\text { ABO blood group and } \\
\text { BMI in a Ghanaian } \\
\text { population }\end{array}$ & Ghana & C & 412 & $\begin{array}{l}\text { Sample included } 238 \text { male and } 174 \text { female } \\
\text { students from KNUST university in Ghana. They } \\
\text { aged from } 18-46 \text { years }\end{array}$ & - \\
\hline $\begin{array}{l}\text { Sodjinou et al. } \\
\text { (2008) }\end{array}$ & $\begin{array}{l}\text { To assess the rate of } \\
\text { obesity and other } \\
\text { cardiovascular disease } \\
\text { (CVD) risk factors in a } \\
\text { random sample of } 200 \\
\text { urban adults in Benin }\end{array}$ & Benin & C & 200 & $\begin{array}{l}\text { Sample included males and females born- } \\
\text { Beninese adults aged } 25 \text { to } 60 \text { years }\end{array}$ & $\begin{array}{l}\text { Multiple linear } \\
\text { regression }\end{array}$ \\
\hline
\end{tabular}




\begin{tabular}{|c|c|c|c|c|c|c|}
\hline Author (year) & Aim & Study setting & $\begin{array}{l}\text { Study } \\
\text { design }\end{array}$ & $\begin{array}{l}\text { Sample } \\
\text { size }\end{array}$ & Sample characteristics & $\begin{array}{l}\text { Primary analysis } \\
\text { /Model(s) used }\end{array}$ \\
\hline & $\begin{array}{l}\text { and explored the } \\
\text { associations between } \\
\text { these factors and socio- } \\
\text { economic status }\end{array}$ & & & & & \\
\hline $\begin{array}{l}\text { Stringhini et al. } \\
(2016)\end{array}$ & $\begin{array}{l}\text { To examine the } \\
\text { association of education } \\
\text { and wealth with several } \\
\text { NCD-Risk factors in } \\
\text { young adults }\end{array}$ & Ghana & $\mathrm{C}$ & 500 & Young adults from 25 to 45 years in rural Ghana & $\begin{array}{l}\text { Ordinary Least } \\
\text { squares }\end{array}$ \\
\hline $\begin{array}{l}\text { Tuoyire et al. } \\
\text { (2018) }\end{array}$ & $\begin{array}{l}\text { To explore the } \\
\text { association between TV } \\
\text { exposure and } \\
\text { overweight/obesity } \\
\text { among Ghanaian }\end{array}$ & Ghana & $\mathrm{C}$ & 4158 & Only women 15 years old and above & $\begin{array}{l}\text { Binary logistic } \\
\text { regression }\end{array}$ \\
\hline
\end{tabular}




\begin{tabular}{|c|c|c|c|c|c|c|}
\hline Author (year) & Aim & Study setting & $\begin{array}{l}\text { Study } \\
\text { design }\end{array}$ & $\begin{array}{l}\text { Sample } \\
\text { size }\end{array}$ & Sample characteristics & $\begin{array}{l}\text { Primary analysis } \\
\text { /Model(s) used }\end{array}$ \\
\hline & women. & & & & & \\
\hline $\begin{array}{l}\text { Tyrovolas et al. } \\
\text { (2016) }\end{array}$ & $\begin{array}{l}\text { To evaluate the factors } \\
\text { associated with low } \\
\text { skeletal muscle mass } \\
\text { (SMM), sarcopenia and } \\
\text { sarcopenic obesity using } \\
\text { nationally } \\
\text { representative samples } \\
\text { of people aged >65years } \\
\text { from diverse geographic } \\
\text { regions }\end{array}$ & Ghana & C & 1,975 & $\begin{array}{l}\text { Sample included both males and females aged } \\
65 \text { years old and above }\end{array}$ & $\begin{array}{l}\text { multivariable } \\
\text { regression }\end{array}$ \\
\hline $\begin{array}{l}\text { Ukegbu et al. } \\
\text { (2017) }\end{array}$ & $\begin{array}{l}\text { To assess prevalence of } \\
\text { overweight and obesity } \\
\text { and associated factors in } \\
\text { a group of university }\end{array}$ & Nigeria & $\mathrm{C}$ & 1610 & $\begin{array}{l}\text { Sample were from five tertiary institutions in } \\
\text { south-eastern states of Nigeria. It included both } \\
\text { males and females and excluded pregnancy or } \\
\text { lactation in women, presence of any form of }\end{array}$ & Chi square test \\
\hline
\end{tabular}




\begin{tabular}{|c|c|c|c|c|c|c|}
\hline Author (year) & Aim & Study setting & $\begin{array}{l}\text { Study } \\
\text { design }\end{array}$ & $\begin{array}{l}\text { Sample } \\
\text { size }\end{array}$ & Sample characteristics & $\begin{array}{l}\text { Primary analysis } \\
\text { /Model(s) used }\end{array}$ \\
\hline & $\begin{array}{l}\text { undergraduates in } \\
\text { south-east Nigeria }\end{array}$ & & & & $\begin{array}{l}\text { physical disability and suffering from any form } \\
\text { of chronic illness. }\end{array}$ & \\
\hline $\begin{array}{l}\text { Wahab et al. } \\
\text { (2011) }\end{array}$ & $\begin{array}{l}\text { To determine the } \\
\text { prevalence of } \\
\text { overweight and obesity } \\
\text { and also determine the } \\
\text { factors that would } \\
\text { independently predict } \\
\text { obesity among } \\
\text { apparently healthy adult } \\
\text { Nigerians in the north } \\
\text { western city of Katsina }\end{array}$ & Nigeria & $\mathrm{C}$ & 300 & $\begin{array}{l}\text { Male and female adults with a mean age of } \\
37.6 \pm 10.6 \text { years }\end{array}$ & logistic regression \\
\hline $\begin{array}{l}\text { Yaya et al. } \\
\text { (2018) }\end{array}$ & $\begin{array}{l}\text { To establish the pattern } \\
\text { of the risk factors of } \\
\text { NCDs in sub-Sahara }\end{array}$ & $\begin{array}{l}\text { Benin, } \\
\text { Burkina Faso } \\
\text { Cameron, }\end{array}$ & $\mathrm{C}$ & 199,540 & $\begin{array}{l}\text { Only women form the participating countries } \\
\text { were included in the studies. Their ages ranged } \\
\text { from } 15 \text { to } 49 \text { years old and were from both }\end{array}$ & $\begin{array}{l}\text { Multinomial } \\
\text { logistic regression }\end{array}$ \\
\hline
\end{tabular}




\begin{tabular}{|c|c|c|c|c|c|c|}
\hline Author (year) & Aim & Study setting & $\begin{array}{l}\text { Study } \\
\text { design }\end{array}$ & $\begin{array}{l}\text { Sample } \\
\text { size }\end{array}$ & Sample characteristics & $\begin{array}{l}\text { Primary analysis } \\
\text { /Model(s) used }\end{array}$ \\
\hline & Africa region & $\begin{array}{l}\text { Ivory Coast } \\
\text { Gambia } \\
\text { Ghana } \\
\text { Guinea Mali } \\
\text { Niger } \\
\text { Nigeria } \\
\text { Liberia } \\
\text { Senegal } \\
\text { Sierra Leone } \\
\text { and Togo }\end{array}$ & & & $\begin{array}{l}\text { rural and urban settlements in the selected } \\
\text { countries. }\end{array}$ & \\
\hline $\begin{array}{l}\text { Ziraba et al. } \\
\text { (2009) }\end{array}$ & $\begin{array}{l}\text { To describe trends in } \\
\text { overweight and obesity } \\
\text { among urban women; } \\
\text { and examine how these } \\
\text { trends vary by }\end{array}$ & $\begin{array}{l}\text { Burkina Faso } \\
\text { Ghana Kenya } \\
\text { Malawi Niger } \\
\text { Tanzania } \\
\text { Senegal. }\end{array}$ & C & - & Comprised women aged $\geq 15$ years & $\begin{array}{l}\text { Multivariate } \\
\text { ordered logistic } \\
\text { regression }\end{array}$ \\
\hline
\end{tabular}




\begin{tabular}{|l|l|l|l|l|l|l|}
\hline Author (year) & Aim & Study setting & Study & Sample & Sample characteristics & Primary analysis \\
\hline & $\begin{array}{l}\text { education and } \\
\text { household wealth }\end{array}$ & & size & & & /Model(s) used \\
\hline
\end{tabular}

C-Cross-sectional study 
Table 4: Independent and dependent variables measured and the study findings

\begin{tabular}{|c|c|c|c|}
\hline Author (year) & Determining variables measured & Obesity specification & Findings \\
\hline Abdula (2010) & $\begin{array}{l}\text { Weight } \\
\text { Household size } \\
\text { Mother/ Child's age } \\
\text { Mother's marriage status } \\
\text { Mother's education } \\
\text { Ethnicity } \\
\text { Mother's occupation } \\
\text { Food consumption } \\
\text { TV Viewing }\end{array}$ & $\begin{array}{l}\text { WHO BMI measure of obesity; } \\
\text { Underweight }<18.50 \mathrm{~kg} / \mathrm{m}^{2} \\
\text { Normal range }(18.50- \\
\left.24.99 \mathrm{~kg} / \mathrm{m}^{2}\right) \\
\text { Overweight }(25.00- \\
\left.29.99 \mathrm{~kg} / \mathrm{m}^{2}\right) \\
\text { Obese }\left(\geq 30 \mathrm{~kg} / \mathrm{m}^{2}\right)\end{array}$ & $\begin{array}{l}\text { Mothers' education, employment status and ethnicity } \\
\text { are associated with obesity }\end{array}$ \\
\hline $\begin{array}{l}\text { Addo et al. } \\
\text { (2015) }\end{array}$ & $\begin{array}{l}\text { Ages } \\
\text { Sex } \\
\text { educational level } \\
\text { marital status }\end{array}$ & $\begin{array}{l}\text { BMI measure of obesity; } \\
\text { Underweight }<18.50 \mathrm{~kg} / \mathrm{m}^{2} \\
\text { Normal range }(18.50- \\
\left.24.99 \mathrm{~kg} / \mathrm{m}^{2}\right)\end{array}$ & $\begin{array}{l}\text { Physical activity }(\mathrm{OR}=0.34,95 \% \mathrm{Cl}=0.13-0.89 \text {, } \\
\mathrm{p}=0.03) \text {, alcohol consumption (OR }=3.00,95 \% \\
\mathrm{Cl}=1.35,6.68, \mathrm{p}=0.007) \text {, marital status (OR }=2.74 \text {, } \\
95 \% \mathrm{Cl}=0.96-7.85, \mathrm{p}=0.04) \text {, sex (OR }=2.78,95 \%\end{array}$ \\
\hline
\end{tabular}




\begin{tabular}{|c|c|c|c|}
\hline Author (year) & Determining variables measured & Obesity specification & Findings \\
\hline & $\begin{array}{l}\text { Years with institution } \\
\text { Sedentary work } \\
\text { Alcohol intake }\end{array}$ & $\begin{array}{l}\text { Overweight }(25.00- \\
\left.29.99 \mathrm{~kg} / \mathrm{m}^{2}\right) \\
\text { Obese }\left(\geq 30 \mathrm{~kg} / \mathrm{m}^{2}\right)\end{array}$ & $\begin{array}{l}\mathrm{Cl}=1.23-6.33, \mathrm{p}=0.01) \text {, and age }(\mathrm{OR}=1.10,95 \% \\
\mathrm{Cl}=1.01-1.20, \mathrm{p}=0.036) \text { were associated with obesity } \\
\text { and overweight }\end{array}$ \\
\hline $\begin{array}{l}\text { Addo \& Leon } \\
\text { (2009) }\end{array}$ & $\begin{array}{l}\text { Age } \\
\text { Physical activity } \\
\text { Level of education } \\
\text { Employment grade } \\
\text { Current wealth } \\
\text { Pre-adult wealth } \\
\text { Alcohol consumption } \\
\text { Smoking status } \\
\text { Ethnicity } \\
\text { Place of birth }\end{array}$ & $\begin{array}{l}\text { BMI measure of obesity; } \\
\text { Underweight }<18.50 \mathrm{~kg} / \mathrm{m}^{2} \\
\text { Normal range }(18.50- \\
\left.24.99 \mathrm{~kg} / \mathrm{m}^{2}\right) \\
\text { Overweight }(25.00- \\
\left.29.99 \mathrm{~kg} / \mathrm{m}^{2}\right) \\
\text { Obese }\left(\geq 30 \mathrm{~kg} / \mathrm{m}^{2}\right)\end{array}$ & $\begin{array}{l}\text { Positive graded association between pre-adult and } \\
\text { adult levels of wealth and the risk of obesity in men ( } P \\
=0.003) \text {, but weak suggestions of an inverse association } \\
\text { between adult level of wealth and obesity in women } \\
\text { under } 45 \text { years of age. }\end{array}$ \\
\hline $\begin{array}{l}\text { Ajayi et al. } \\
(2016)\end{array}$ & $\begin{array}{l}\text { Sex } \\
\text { Age } \\
\text { Education level }\end{array}$ & $\begin{array}{l}\text { BMI measure of obesity; } \\
\text { Underweight }<18.50 \mathrm{~kg} / \mathrm{m}^{2} \\
\text { Normal range }(18.50-\end{array}$ & $\begin{array}{l}\text { Female predicted obesity and overweight in peri-urban } \\
\text { Uganda ( } A O R=8.01, \mathrm{Cl}=4.02-15.96 \text { ) and obesity in } \\
\text { rural Uganda ( } A O R=11.22, \mathrm{Cl}=2.27-55.40 \text { ), peri-urban }\end{array}$ \\
\hline
\end{tabular}




\begin{tabular}{|c|c|c|c|}
\hline Author (year) & Determining variables measured & Obesity specification & Findings \\
\hline & $\begin{array}{l}\text { Marital status } \\
\text { Cigarette smoking } \\
\text { Number of cigarettes in past } 24 \mathrm{~h} \\
\text { Wealth status } \\
\text { Current smoker }\end{array}$ & $\begin{array}{l}\left.24.99 \mathrm{~kg} / \mathrm{m}^{2}\right) \\
\text { Overweight }(25.00- \\
\left.29.99 \mathrm{~kg} / \mathrm{m}^{2}\right) \\
\text { Obese }\left(\geq 30 \mathrm{~kg} / \mathrm{m}^{2}\right)\end{array}$ & $\begin{array}{l}\text { Uganda ( } \mathrm{AOR}=27.80, \mathrm{Cl}=7.13-108.41 \text { ) and South } \\
\text { Africa ( } \mathrm{AOR}=2.17, \mathrm{Cl}: 1.19-4.00 \text { ). } \\
\text { Increasing age predicted } \mathrm{BMI} \geq 25 \mathrm{~kg} / \mathrm{m}^{2} \text { in Nigeria (Age> } \\
=45, \mathrm{AOR}=9.11,1.72-48.16 \text { ) and South Africa (AOR } \\
=6.22, \mathrm{Cl}=2.75-14.07 \text { ), while marital status predicted } \\
\mathrm{BMI} \geq 25 \mathrm{~kg} / \mathrm{m}^{2} \text { only in peri-urban Uganda (Married - } \\
\mathrm{AOR}=4.49, \mathrm{Cl}: 1.74-11.57 \text { ). }\end{array}$ \\
\hline $\begin{array}{l}\text { Akarolo- } \\
\text { Anthony et al. } \\
\text { (2014) }\end{array}$ & $\begin{array}{l}\text { Age } \\
\text { Sex } \\
\text { Religion } \\
\text { Marital status } \\
\text { Education } \\
\text { Occupation } \\
\text { Socio-economic status } \\
\text { Sugar sweetened beverages } \\
\text { Physical activity }\end{array}$ & $\begin{array}{l}\text { BMI measure of obesity; } \\
\text { Underweight }<18.50 \mathrm{~kg} / \mathrm{m}^{2} \\
\text { Normal range }(18.50- \\
\left.24.99 \mathrm{~kg} / \mathrm{m}^{2}\right) \\
\text { Overweight }(25.00- \\
\left.29.99 \mathrm{~kg} / \mathrm{m}^{2}\right) \\
\text { Obese }\left(\geq 30 \mathrm{~kg} / \mathrm{m}^{2}\right) .\end{array}$ & $\begin{array}{l}\text { Compared with the individuals in the lower socio- } \\
\text { economic status, the PR of obesity among those in the } \\
\text { middle and high socio-economic statuses were } 1.39, \mathrm{Cl} \\
=1.13-1.72 \text { and } 1.24, \mathrm{Cl}=0.97-1.59 \text { respectively. }\end{array}$ \\
\hline
\end{tabular}




\begin{tabular}{|c|c|c|c|}
\hline Author (year) & Determining variables measured & Obesity specification & Findings \\
\hline & Television & & \\
\hline $\begin{array}{l}\text { Akinyeniju et al. } \\
\text { (2016) }\end{array}$ & $\begin{array}{l}\text { Age } \\
\text { Marital status } \\
\text { Smoking } \\
\text { Alcohol use } \\
\text { Health status } \\
\text { Education } \\
\text { Mother's education } \\
\text { Father's education } \\
\text { Employment }\end{array}$ & $\begin{array}{l}\text { BMI measure of obesity; } \\
\text { Underweight }<18.50 \mathrm{~kg} / \mathrm{m}^{2} \\
\text { Normal range }(18.50- \\
\left.24.99 \mathrm{~kg} / \mathrm{m}^{2}\right) \\
\text { Overweight }(25.00- \\
\left.29.99 \mathrm{~kg} / \mathrm{m}^{2}\right) \\
\text { Obese }\left(\geq 30 \mathrm{~kg} / \mathrm{m}^{2}\right)\end{array}$ & $\begin{array}{l}\text { Participants whose mothers were employed in the } \\
\text { public sector had significantly higher BMI compared } \\
\text { with those who were unemployed ( } 24.7 \text { vs } 22.4 \text { ); and } \\
\text { participants whose fathers were employed in the public } \\
\text { sector had higher BMI compared with those whose } \\
\text { fathers were unemployed ( } 25.3 \text { vs } 19.00 \text { ). Life-course } \\
\text { SES based on both maternal ( } p=0 / 0339 \text { ) and paternal } \\
\text { ( } p=0.0062 \text { ) education and paternal employment } \\
\text { ( } p<0.0001 \text { ) were each associated with BMI }\end{array}$ \\
\hline $\begin{array}{l}\text { Aladeniyi et al. } \\
\text { (2017) }\end{array}$ & $\begin{array}{l}\text { Sex } \\
\text { Age } \\
\text { Level of education } \\
\text { Marital status }\end{array}$ & $\begin{array}{l}\text { BMI measure of obesity; } \\
\text { Underweight }<18.50 \mathrm{~kg} / \mathrm{m}^{2} \\
\text { Normal range }(18.50- \\
\left.24.99 \mathrm{~kg} / \mathrm{m}^{2}\right)\end{array}$ & $\begin{array}{l}\text { Female }(A O R=5.7 \mathrm{Cl}=4.7-6.9) \text {, age }(A O R=1.4, C l=1.1- \\
\text { 1.8), level of education }(A O R=0.8, C l=0.7-0.9) \text {, marital } \\
\text { status ( } A O R=2.1, \mathrm{Cl}=1.7-2.8) \text {, alcohol consumption } \\
(A O R=0.7, \mathrm{Cl}=0.5-0.9) \text {, diabetes mellitus ( } A O R=0.7, \mathrm{Cl}=\end{array}$ \\
\hline
\end{tabular}




\begin{tabular}{|c|c|c|c|}
\hline Author (year) & Determining variables measured & Obesity specification & Findings \\
\hline & $\begin{array}{l}\text { Grade level } \\
\text { Excessive alcohol consumption } \\
\text { Engaging in physical activity } \\
\text { Spending } 8 \text { or > hours in sitting } \\
\text { Diabetes mellitus } \\
\text { High blood pressure }\end{array}$ & $\begin{array}{l}\text { Overweight }(25.00- \\
\left.29.99 \mathrm{~kg} / \mathrm{m}^{2}\right) \\
\text { Obese }\left(\geq 30 \mathrm{~kg} / \mathrm{m}^{2}\right)\end{array}$ & $\begin{array}{l}0.5-0.9) \text { and hypertension ( } \mathrm{AOR}=0.5, \mathrm{Cl}=0.4-0.6 \text { ) } \\
\text { predict obesity }\end{array}$ \\
\hline $\begin{array}{l}\text { Engle-Stone et } \\
\text { al. (2018) }\end{array}$ & $\begin{array}{l}\text { Age } \\
\text { Household socio-economic status } \\
\text { Exposure to media } \\
\text { Intake of fortified food } \\
\text { Consumption of processed snack }\end{array}$ & $\begin{array}{l}\text { BMI measure of obesity; } \\
\text { Underweight }<18.50 \mathrm{~kg} / \mathrm{m}^{2} \\
\text { Normal range }(18.50- \\
\left.24.99 \mathrm{~kg} / \mathrm{m}^{2}\right) \\
\text { Overweight }(25.00- \\
\left.29.99 \mathrm{~kg} / \mathrm{m}^{2}\right) \\
\text { Obese }\left(\geq 30 \mathrm{~kg} / \mathrm{m}^{2}\right) .\end{array}$ & $\begin{array}{l}\text { Household TV ownership }(\mathrm{OR}=0.31 \mathrm{Cl}=0.11,0.92)] \text { and } \\
\text { age }(\mathrm{OR}=0.38 \mathrm{Cl}=0.12,1.20) \text { were associated with } \\
\text { obesity }\end{array}$ \\
\hline $\begin{array}{l}\text { Atuahene et al. } \\
\text { (2017) }\end{array}$ & $\begin{array}{l}\text { Age } \\
\text { Sex } \\
\text { Marital status }\end{array}$ & $\begin{array}{l}\text { BMI measure of obesity; } \\
\text { Underweight }<18.50 \mathrm{~kg} / \mathrm{m}^{2} \\
\text { Normal range }(18.50-\end{array}$ & $\begin{array}{l}\text { Marital status ( } p=0.001 \text { ), leisure time with physical } \\
\text { activity }(p=0.000) \text { and level of physical activity at work } \\
(p=0.035) \text { were significantly associated with BMI. }\end{array}$ \\
\hline
\end{tabular}




\begin{tabular}{|c|c|c|c|}
\hline Author (year) & Determining variables measured & Obesity specification & Findings \\
\hline & $\begin{array}{l}\text { Religion } \\
\text { Highest education level } \\
\text { Alcohol consumption } \\
\text { Smoking } \\
\text { Most important meal } \\
\text { Skipping breakfast } \\
\text { Last meal of the day } \\
\text { Exercise } \\
\text { Leisure time } \\
\text { Level of physical activity } \\
\text { Means of transport }\end{array}$ & $\begin{array}{l}\left.24.99 \mathrm{~kg} / \mathrm{m}^{2}\right) \\
\text { Overweight }(25.00- \\
\left.29.99 \mathrm{~kg} / \mathrm{m}^{2}\right) \\
\text { Obese }\left(\geq 30 \mathrm{~kg} / \mathrm{m}^{2}\right)\end{array}$ & \\
\hline $\begin{array}{l}\text { Becquey et al. } \\
\text { (2010) }\end{array}$ & $\begin{array}{l}\text { Snacking score (frequent food } \\
\text { consumption outside the main } \\
\text { meals) } \\
\text { Modern foods score (modernity of } \\
\text { the type of foods consumed) }\end{array}$ & $\begin{array}{l}\text { BMI measure of obesity; } \\
\text { Underweight }<18.50 \mathrm{~kg} / \mathrm{m}^{2} \\
\text { Normal range }(18.50- \\
\left.24.99 \mathrm{~kg} / \mathrm{m}^{2}\right) \\
\text { Overweight }(25.00-\end{array}$ & $\begin{array}{l}\text { A higher "modern foods" score was associated with a } \\
\text { higher prevalence of overweight when confounding } \\
\text { factors were accounted for (OR = } 1.19 \text { [95\% } \mathrm{Cl} 1.03 \text { - } \\
1.36] \text { ) }\end{array}$ \\
\hline
\end{tabular}




\begin{tabular}{|c|c|c|c|}
\hline Author (year) & Determining variables measured & Obesity specification & Findings \\
\hline & $\begin{array}{l}\text { Age } \\
\text { Marital status } \\
\text { Religion } \\
\text { Ever attended school } \\
\text { District }\end{array}$ & $\begin{array}{l}\left.29.99 \mathrm{~kg} / \mathrm{m}^{2}\right) \\
\text { Obese }\left(\geq 30 \mathrm{~kg} / \mathrm{m}^{2}\right) \text {. }\end{array}$ & \\
\hline $\begin{array}{l}\text { Ghose B. \& Yaya } \\
\text { S. (2018) }\end{array}$ & $\begin{array}{l}\text { Frequency of reading newspapers } \\
\text { Listening to radio } \\
\text { Television (TV) viewing }\end{array}$ & $\begin{array}{l}\text { BMI measure of obesity; } \\
\text { Underweight }<18.50 \mathrm{~kg} / \mathrm{m}^{2} \\
\text { Normal range }(18.50- \\
\left.24.99 \mathrm{~kg} / \mathrm{m}^{2}\right) \\
\text { Overweight }(25.00- \\
\left.29.99 \mathrm{~kg} / \mathrm{m}^{2}\right) \\
\text { Obese }\left(\geq 30 \mathrm{~kg} / \mathrm{m}^{2}\right)\end{array}$ & $\begin{array}{l}\text { Watching TV almost every day and at least once a week } \\
\text { were associated with, respectively, } 1.6(\mathrm{Cl}=1.412- \\
1.811) \text { and } 1.2(\mathrm{Cl}=1.053-1.363) \text { times higher odds of } \\
\text { being overweight, and } 2.7(\mathrm{Cl}=2.432-3.037) \text { and } 1.5 \\
(\mathrm{Cl}=1.053-1.63) \text { times higher odds of being obese } \\
\text { compared with those who never used radio. }\end{array}$ \\
\hline $\begin{array}{l}\text { Blankson \& Hall } \\
\text { (2010) }\end{array}$ & $\begin{array}{l}\text { Half arm span } \\
\text { Mid-upper arm circumference } \\
\text { (MUaC) } \\
\text { Age }\end{array}$ & $\begin{array}{l}\text { BMI measure of obesity; } \\
\text { Underweight }<18.50 \mathrm{~kg} / \mathrm{m}^{2} \\
\text { Normal range }(18.50- \\
\left.24.99 \mathrm{~kg} / \mathrm{m}^{2}\right)\end{array}$ & $\begin{array}{l}\text { BMI was strongly positively correlated with half arm } \\
\text { span }(r=0.999, P<0.001) \text { and with } \mathrm{MUaC}(r=0.91 \text {, } \\
\mathrm{P}<0.001) \text {. }\end{array}$ \\
\hline
\end{tabular}




\begin{tabular}{|c|c|c|c|}
\hline Author (year) & Determining variables measured & Obesity specification & Findings \\
\hline & $\begin{array}{l}\text { Chewing tobacco } \\
\text { Drinking alcohol } \\
\text { Using walking aid }\end{array}$ & $\begin{array}{l}\text { Overweight }(25.00- \\
\left.29.99 \mathrm{~kg} / \mathrm{m}^{2}\right) \\
\text { Obese }\left(\geq 30 \mathrm{~kg} / \mathrm{m}^{2}\right)\end{array}$ & \\
\hline $\begin{array}{l}\text { Boua et al. } \\
\text { (2018) }\end{array}$ & $\begin{array}{l}\text { Age } \\
\text { Gender } \\
\text { Ethnicity } \\
\text { Marital status } \\
\text { Highest level of education } \\
\text { Employment } \\
\text { Household asset status } \\
\text { Smoking status } \\
\text { Snuff use } \\
\text { Chewing tobacco } \\
\text { Alcohol intake } \\
\text { Diet }\end{array}$ & $\begin{array}{l}\text { BMI measure of obesity; } \\
\text { Underweight }<18.50 \mathrm{~kg} / \mathrm{m}^{2} \\
\text { Normal range }(18.50- \\
\left.24.99 \mathrm{~kg} / \mathrm{m}^{2}\right) \\
\text { Overweight }(25.00- \\
\left.29.99 \mathrm{~kg} / \mathrm{m}^{2}\right) \\
\text { Obese }\left(\geq 30 \mathrm{~kg} / \mathrm{m}^{2}\right)\end{array}$ & $\begin{array}{l}\text { Age was inversely associated with } \mathrm{BMI} \text { in men ( } \beta=- \\
0.09, \mathrm{Cl}=-0.12 \text { to }-0.69 \text { ). Problematic drinking was } \\
\text { associated with a decreased in } \mathrm{BMI} \text { by } 0.89 \text { units ( } \mathrm{Cl}=- \\
1.54 \text { to }-0.24 \text { ) compared to those who never consumed } \\
\text { alcohol, whereas smoking was found to be associated } \\
\text { with a decreased of } 2 \mathrm{BMI} \text { units ( } \beta=-2.0, \mathrm{Cl}=-2.59 \text { to - } \\
\text { 1.41) compared to those who never smoked. Among } \\
\text { women, chewing tobacco was associated with a } \mathrm{BMI} \\
\text { decrease ( } \beta=-0.79, \mathrm{Cl}=-1.2 \text { to }-0.37 \text { ). }\end{array}$ \\
\hline
\end{tabular}




\begin{tabular}{|c|c|c|c|}
\hline Author (year) & Determining variables measured & Obesity specification & Findings \\
\hline & $\begin{array}{l}\text { Physical activity } \\
\text { Clinical history } \\
\text { Self-reported diabetes status } \\
\text { HIV positive } \\
\text { TB positive }\end{array}$ & & \\
\hline $\begin{array}{l}\text { Chigbu et al. } \\
\text { (2018) }\end{array}$ & $\begin{array}{l}\text { Gender } \\
\text { Age } \\
\text { Residence } \\
\text { Urban class } \\
\text { Marital status } \\
\text { Education level } \\
\text { Income status } \\
\text { Ethnicity }\end{array}$ & $\begin{array}{l}\text { BMI measure of obesity; } \\
\text { Underweight }<18.50 \mathrm{~kg} / \mathrm{m}^{2} \\
\text { Normal range }(18.50- \\
\left.24.99 \mathrm{~kg} / \mathrm{m}^{2}\right) \\
\text { Overweight }(25.00- \\
\left.29.99 \mathrm{~kg} / \mathrm{m}^{2}\right) \\
\text { Obese }\left(\geq 30 \mathrm{~kg} / \mathrm{m}^{2}\right)\end{array}$ & 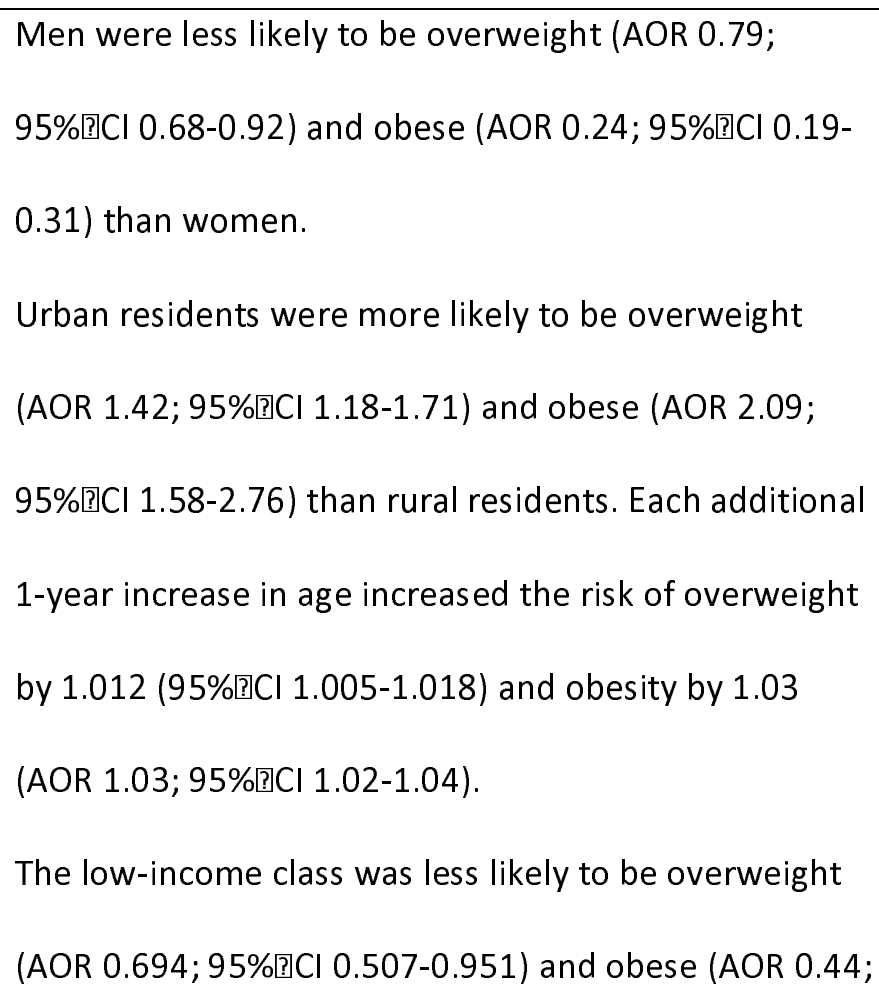 \\
\hline
\end{tabular}




\begin{tabular}{|c|c|c|c|}
\hline Author (year) & Determining variables measured & Obesity specification & Findings \\
\hline & & & $95 \%$ 回 $\mathrm{Cl} 0.28-0.67)$. \\
\hline $\begin{array}{l}\text { Chukwuonye et } \\
\text { al. (2013) }\end{array}$ & $\begin{array}{l}\text { Hypertension } \\
\text { Diabetes mellitus }\end{array}$ & $\begin{array}{l}\text { BMI (Underweight } \\
<18.50 \mathrm{~kg} / \mathrm{m}^{2} \\
\text { Normal range }(18.5- \\
\left.24.99 \mathrm{~kg} / \mathrm{m}^{2}\right) \\
\text { Overweight }(25.00- \\
\left.29.99 \mathrm{~kg} / \mathrm{m}^{2}\right) \\
\text { Obese }\left(\geq 30 \mathrm{~kg} / \mathrm{m}^{2}\right) . \\
\text { Abdominal obesity (Waist } \\
\text { circumference of } 102 \mathrm{~cm} \text { or } \\
\text { more in men and } 88 \mathrm{~cm} \text { or } \\
\text { more in women }\end{array}$ & $\begin{array}{l}\text { The prevalence of abdominal obesity was higher } \\
(21.75 \%) \text { than the prevalence of obesity based on BMI } \\
(11.12 \%) \text { in the population. }\end{array}$ \\
\hline $\begin{array}{l}\text { Cohen et al. } \\
\text { (2018) }\end{array}$ & $\begin{array}{l}\text { Dietary intake } \\
\text { Physical activity } \\
\text { Health status perception } \\
\text { Anthropometry variables }\end{array}$ & $\begin{array}{l}\text { BMI measure of obesity; } \\
\text { Underweight }<18.50 \mathrm{~kg} / \mathrm{m}^{2} \\
\text { Normal range }(18.50- \\
\left.24.99 \mathrm{~kg} / \mathrm{m}^{2}\right)\end{array}$ & $\begin{array}{l}\text { Being female, older, living in urban/suburban areas and } \\
\text { valuing larger body size were independently associated } \\
\text { with being overweight/obese, but not high-calorie diet }\end{array}$ \\
\hline
\end{tabular}




\begin{tabular}{|c|c|c|c|}
\hline Author (year) & Determining variables measured & Obesity specification & Findings \\
\hline & Perceptions of corpulence & $\begin{array}{l}\text { Overweight (25.00- } \\
\left.29.99 \mathrm{~kg} / \mathrm{m}^{2}\right) \\
\text { Obese }\left(\geq 30 \mathrm{~kg} / \mathrm{m}^{2}\right)\end{array}$ & \\
\hline $\begin{array}{l}\text { Corsi et al. } \\
\text { (2010) }\end{array}$ & $\begin{array}{l}\text { Age } \\
\text { Education } \\
\text { Household wealth } \\
\text { Neighbourhood of respondent }\end{array}$ & $\begin{array}{l}\text { BMI measure of obesity; } \\
\text { Underweight }<18.50 \mathrm{~kg} / \mathrm{m}^{2} \\
\text { Normal range }(18.50- \\
\left.24.99 \mathrm{~kg} / \mathrm{m}^{2}\right) \\
\text { Overweight }(25.00- \\
\left.29.99 \mathrm{~kg} / \mathrm{m}^{2}\right) \\
\text { Obese }\left(\geq 30 \mathrm{~kg} / \mathrm{m}^{2}\right) .\end{array}$ & $\begin{array}{l}\text { Of the total variation in BMI, 17.6\% was attributable to } \\
\text { countries (SD 2.0, 95\% Cl 1.7, 2.4) and 10.6\% (SD 1.56, } \\
95 \% \mathrm{Cl} 1.54,1.58 \text { ) was attributable to neighbourhoods } \\
\text { in age-adjusted models. Adjusting for individual- and } \\
\text { neighbourhood-level covariates reduced the SD } \\
\text { attributable to countries and neighbourhoods to 1.9, } \\
\text { and 1.17, respectively. Between-country variation was } \\
13.4 \% \text { (SD 0.75, 95\% Cl 0.62-0.90) for underweight and } \\
18.9 \% \text { (SD 0.92, 95\% Cl 0.76-1.10) for overweight, and } \\
\text { between-neighbourhood variation was 7.7\% (SD 0.57, } \\
95 \% \mathrm{Cl} 0.55-0.58 \text { ) for underweight and 7.1\% (SD 0.56, } \\
95 \% \mathrm{Cl} 0.55-0.58 \text { ) for overweight in the fully-adjusted } \\
\text { multinomial model. }\end{array}$ \\
\hline
\end{tabular}




\begin{tabular}{|c|c|c|c|}
\hline Author (year) & Determining variables measured & Obesity specification & Findings \\
\hline $\begin{array}{l}\text { Dake et al. } \\
\text { (2011) }\end{array}$ & $\begin{array}{l}\text { Age } \\
\text { place of residence } \\
\text { region of residence } \\
\text { level of education } \\
\text { ethnicity } \\
\text { religion } \\
\text { occupation } \\
\text { marital status } \\
\text { parity } \\
\text { household wealth quintile }\end{array}$ & $\begin{array}{l}\text { BMI measure of obesity; } \\
\text { Underweight }<18.50 \mathrm{~kg} / \mathrm{m}^{2} \\
\text { Normal range }(18.50- \\
\left.24.99 \mathrm{~kg} / \mathrm{m}^{2}\right) \\
\text { Overweight }(25.00- \\
\left.29.99 \mathrm{~kg} / \mathrm{m}^{2}\right) \\
\text { Obese }\left(\geq 30 \mathrm{~kg} / \mathrm{m}^{2}\right) .\end{array}$ & $\begin{array}{l}\text { Women who had higher education were about two } \\
\text { times more likely to be overweight compared to non- } \\
\text { educated women; those from richer households were } \\
\text { twice as likely to be overweight and about five times as } \\
\text { likely to be obese compared to those from households } \\
\text { of average wealth status. The likelihood of a woman } \\
\text { being overweight or obese increased with increasing } \\
\text { age. }\end{array}$ \\
\hline $\begin{array}{l}\text { Dake et al. } \\
\text { (2016) }\end{array}$ & $\begin{array}{l}\text { Characteristics of the food } \\
\text { environment } \\
\text { Age } \\
\text { Sex } \\
\text { Marital status } \\
\text { Education level }\end{array}$ & $\begin{array}{l}\text { BMI measure of obesity; } \\
\text { Underweight }<18.50 \mathrm{~kg} / \mathrm{m}^{2} \\
\text { Normal range }(18.50- \\
\left.24.99 \mathrm{~kg} / \mathrm{m}^{2}\right) \\
\text { Overweight }(25.00- \\
\left.29.99 \mathrm{~kg} / \mathrm{m}^{2}\right)\end{array}$ & $\begin{array}{l}\text { The findings showed a } 0.2 \mathrm{~kg} / \mathrm{m}^{2} \text { increase in BMI for } \\
\text { every additional convenience store and a } 0.1 \mathrm{~kg} / \mathrm{m}^{2} \\
\text { reduction in BMI for every out-of-home cooked food } \\
\text { place available after controlling for individual socio- } \\
\text { demographic characteristics, lifestyle behaviours and } \\
\text { community characteristics. }\end{array}$ \\
\hline
\end{tabular}




\begin{tabular}{|c|c|c|c|}
\hline Author (year) & Determining variables measured & Obesity specification & Findings \\
\hline & $\begin{array}{l}\text { Type of occupation } \\
\text { Length of stay in the community } \\
\text { Social cohesion } \\
\text { Crime level } \\
\text { Trust among community members } \\
\text { Lifestyle behaviours }\end{array}$ & Obese $\left(\geq 30 \mathrm{~kg} / \mathrm{m}^{2}\right)$ & \\
\hline Dake (2012) & $\begin{array}{l}\text { GPS data (Spatial location, } \\
\text { determined using the local spatial } \\
\text { autocorrelation (LISA)) }\end{array}$ & $\begin{array}{l}\text { BMI measure of obesity; } \\
\text { Underweight }<18.50 \mathrm{~kg} / \mathrm{m}^{2} \\
\text { Normal range }(18.50- \\
\left.24.99 \mathrm{~kg} / \mathrm{m}^{2}\right) \\
\text { Overweight }(25.00- \\
\left.29.99 \mathrm{~kg} / \mathrm{m}^{2}\right) \\
\text { Obese }\left(\geq 30 \mathrm{~kg} / \mathrm{m}^{2}\right) .\end{array}$ & $\begin{array}{l}\text { The results indicate that almost a quarter of clusters in } \\
\text { Ghana contain women who are mostly overweight on } \\
\text { average. }\end{array}$ \\
\hline $\begin{array}{l}\text { Damorou et al. } \\
\text { (2013) }\end{array}$ & $\begin{array}{l}\text { Age } \\
\text { Gender }\end{array}$ & $\begin{array}{l}\text { BMI ((Underweight } \\
<18.50 \mathrm{~kg} / \mathrm{m}^{2}\end{array}$ & $\begin{array}{l}\text { Low education level (OR } 2.45,95 \% \mathrm{Cl} 1.78-4.55, \mathrm{p} \\
=0.001) \text { and lack of physical activity (OR } 3.57,95 \% \mathrm{Cl}\end{array}$ \\
\hline
\end{tabular}




\begin{tabular}{|c|c|c|c|}
\hline Author (year) & Determining variables measured & Obesity specification & Findings \\
\hline & $\begin{array}{l}\text { Education level } \\
\text { Dietary habits } \\
\text { Total cholesterol } \\
\text { Fasting blood sugar } \\
\text { Blood pressure }\end{array}$ & $\begin{array}{l}\text { Normal range }(18.5- \\
\left.24.99 \mathrm{~kg} / \mathrm{m}^{2}\right) \\
\text { Overweight }(25.00- \\
\left.29.99 \mathrm{~kg} / \mathrm{m}^{2}\right) \\
\left.\text { Obese }\left(\geq 30 \mathrm{~kg} / \mathrm{m}^{2}\right)\right) \\
\text { and waist circumference } \\
(W C) \text { : measured as }>88 \mathrm{~cm} \text { for } \\
\text { females and }>102 \mathrm{~cm} \text { for } \\
\text { males. }\end{array}$ & $\begin{array}{l}2.34-9.67, p=0.001) \text { were significantly associated with } \\
\text { obesity. }\end{array}$ \\
\hline $\begin{array}{l}\text { Dickson et al. } \\
\text { (2016) }\end{array}$ & $\begin{array}{l}\text { Maternal DDS } \\
\text { Maternal parity } \\
\text { Maternal age (in years) } \\
\text { Number of household members } \\
\text { Number of children under } 5 \text { years } \\
\text { Education } \\
\text { Employment status }\end{array}$ & $\begin{array}{l}\text { BMI: (Underweight } \\
<18.50 \mathrm{~kg} / \mathrm{m}^{2} \\
\text { Normal range }(18.5- \\
\left.24.99 \mathrm{~kg} / \mathrm{m}^{2}\right) \\
\text { Overweight }(25.00- \\
\left.29.99 \mathrm{~kg} / \mathrm{m}^{2}\right) \\
\text { Obese }\left(\geq 30 \mathrm{~kg} / \mathrm{m}^{2}\right)\end{array}$ & $\begin{array}{l}\text { Women who consumed an additional unit of DD } \\
\text { achieved an increase of } 0.245 \text { in BMI for those in the } \\
\text { 90th quantile. The effect of household wealth increases } \\
\text { for individuals across all quantiles of the BMI } \\
\text { distribution. A unit change in the household wealth } \\
\text { score was associated with an increase of } 0.038 \text { units } \\
\text { increase in BMI for individuals in the 5th quantile in }\end{array}$ \\
\hline
\end{tabular}




\begin{tabular}{|c|c|c|c|}
\hline Author (year) & Determining variables measured & Obesity specification & Findings \\
\hline & $\begin{array}{l}\text { Household wealth } \\
\text { Sex of household head } \\
\text { Presence of co-wives }\end{array}$ & & $\begin{array}{l}\text { Ghana. Also, } 0.237 \text { units increased for those in the 90th } \\
\text { quantile in Ghana. }\end{array}$ \\
\hline $\begin{array}{l}\text { Diendéré et al. } \\
\text { (2019) }\end{array}$ & $\begin{array}{l}\text { Age } \\
\text { Marital status Residence } \\
\text { Education levels Occupation } \\
\text { Total cholesterol } \\
\text { Blood pressure } \\
\text { Alcohol use } \\
\text { Smoking tobacco }\end{array}$ & $\begin{array}{l}\text { BMI: (Underweight } \\
<18.50 \mathrm{~kg} / \mathrm{m}^{2} \\
\text { Normal range }(18.5- \\
\left.24.99 \mathrm{~kg} / \mathrm{m}^{2}\right) \\
\text { Overweight }(25.00- \\
\left.29.99 \mathrm{~kg} / \mathrm{m}^{2}\right) \\
\text { Obese }\left(\geq 30 \mathrm{~kg} / \mathrm{m}^{2}\right) .\end{array}$ & $\begin{array}{l}\text { Being a resident of a region in the highest urbanization } \\
\text { rate quartile, having a high level of total cholesterol } \\
\text { (alone or via an interaction with age) and having a high } \\
\text { BP was significantly associated with obesity }\end{array}$ \\
\hline $\begin{array}{l}\text { Doku \& } \\
\text { Neupane (2015) }\end{array}$ & $\begin{array}{l}\text { Age } \\
\text { Education } \\
\text { Parity } \\
\text { Marital status } \\
\text { Wealth index }\end{array}$ & $\begin{array}{l}\text { BMI: (Underweight } \\
<18.50 \mathrm{~kg} / \mathrm{m}^{2} \\
\text { Normal range (18.5- } \\
\left.24.99 \mathrm{~kg} / \mathrm{m}^{2}\right) \\
\text { Overweight }(25.00-\end{array}$ & 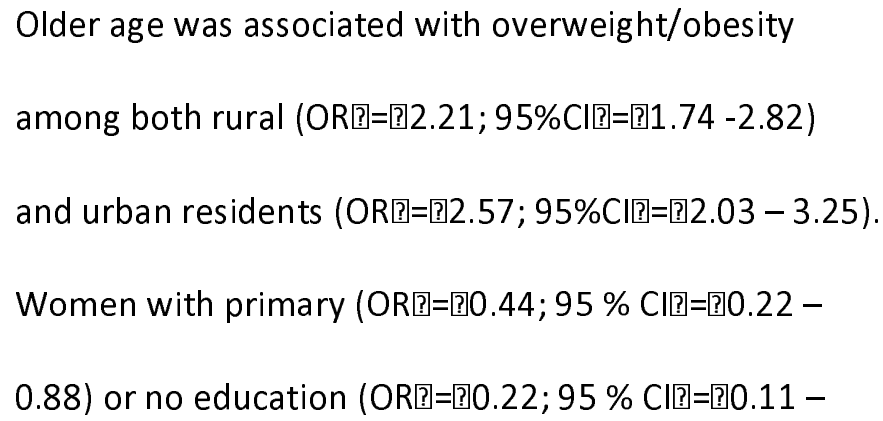 \\
\hline
\end{tabular}




\begin{tabular}{|c|c|c|c|}
\hline Author (year) & Determining variables measured & Obesity specification & Findings \\
\hline & $\begin{array}{l}\text { Place of residence } \\
\text { Survey year }\end{array}$ & $\begin{array}{l}\left.29.99 \mathrm{~kg} / \mathrm{m}^{2}\right) \\
\text { Obese }\left(\geq 30 \mathrm{~kg} / \mathrm{m}^{2}\right)\end{array}$ & $\begin{array}{l}0.44 \text { ) had lesser likelihood of being overweight/obese, } \\
\text { especially among rural residents. Women with no } \\
\text { education (OR? } 0.48 ; 95 \% \mathrm{CI}=0.32-0.72 \text { ) were } \\
\text { also less likely of being overweight/obese among urban } \\
\text { residents. }\end{array}$ \\
\hline $\begin{array}{l}\text { Maruf \& Udoji } \\
\text { (2015) }\end{array}$ & $\begin{array}{l}\text { Socio-economic status } \\
\text { (occupational and educational } \\
\text { indices. }\end{array}$ & $\begin{array}{l}\text { BMI: (Underweight } \\
<18.50 \mathrm{~kg} / \mathrm{m}^{2} \\
\text { Normal range }(18.5- \\
\left.24.99 \mathrm{~kg} / \mathrm{m}^{2}\right) \\
\text { Overweight }(25.00- \\
\left.29.99 \mathrm{~kg} / \mathrm{m}^{2}\right) \\
\text { Obese }\left(\geq 30 \mathrm{~kg} / \mathrm{m}^{2}\right)\end{array}$ & $\begin{array}{l}\text { Participants aged } 41-60 \text { years (OR } 4.29 ; 95 \% \mathrm{Cl}, 3.25- \\
5.67 \text { ) had higher odds for Obesity and those }>60 \text { years } \\
\text { (OR } 1.72 ; 95 \% \mathrm{Cl}, 1.21-2.43 \text { ) had higher odds for } \\
\text { overweight compared to those aged } 18-40 \text { years. } \\
\text { Female was associated overweight (OR } 1.20 ; 95 \% \mathrm{Cl} \text {, } \\
0.96-1.51 \text { ) and obesity (OR } 2.21 ; 95 \% \mathrm{Cl}, 1.73-2.83 \text { ). } \\
\text { Participants with secondary education had marginally } \\
\text { higher odds for overweight (OR } 1.15 ; 95 \% \mathrm{Cl}, 0.88- \\
\text { 1.51) and obesity (OR } 1.17 ; 95 \% \mathrm{Cl}, 0.86-1.59 \text { ) than } \\
\text { those with tertiary education. } \\
\text { and while skilled participants had about the same OR }\end{array}$ \\
\hline
\end{tabular}




\begin{tabular}{|c|c|c|c|}
\hline Author (year) & Determining variables measured & Obesity specification & Findings \\
\hline & & & $\begin{array}{l}\text { for overweight as professionals, their OR for obesity } \\
\text { (OR } 1.27 ; 95 \% \mathrm{Cl}, 0.67-2.43 \text { ) was fairly higher than that } \\
\text { for professionals. }\end{array}$ \\
\hline $\begin{array}{l}\text { Fezeu at al. } \\
(2005)\end{array}$ & $\begin{array}{l}\text { Age } \\
\text { Gender } \\
\text { Household amenities quartile } \\
\text { Occupation level } \\
\text { Alcohol consumption } \\
\text { Tobacco smoking } \\
\text { Educational level } \\
\text { Physical activity quartile }\end{array}$ & $\begin{array}{l}\text { BMI: (Underweight } \\
<18.50 \mathrm{~kg} / \mathrm{m}^{2} \\
\text { Normal range (18.5- } \\
\left.24.99 \mathrm{~kg} / \mathrm{m}^{2}\right) \\
\text { Overweight }(25.00- \\
\left.29.99 \mathrm{~kg} / \mathrm{m}^{2}\right) \\
\text { Obese }\left(\geq 30 \mathrm{~kg} / \mathrm{m}^{2}\right) .\end{array}$ & $\begin{array}{l}\text { After adjusting for confounding variables, the odds of } \\
\text { obesity (3.8, 1.8-7.8), and abdominal obesity }(2.2,1.3- \\
\text { 3.6) were significantly higher for men in the high } \\
\text { compared with the low occupational level. }\end{array}$ \\
\hline $\begin{array}{l}\text { Fezeu et al. } \\
\text { (2008) }\end{array}$ & $\begin{array}{l}\text { Age } \\
\text { Alcohol consumption } \\
\text { tobacco smoking, } \\
\text { educational level. }\end{array}$ & $\begin{array}{l}\text { BMI: (Underweight } \\
<18.50 \mathrm{~kg} / \mathrm{m}^{2} \\
\text { Normal range }(18.5- \\
\left.24.99 \mathrm{~kg} / \mathrm{m}^{2}\right) \\
\text { Overweight }(25.00-\end{array}$ & $\begin{array}{l}\text { Age-standardized prevalence of } \mathrm{BMI} \geq 25 \mathrm{~kg} / \mathrm{m}^{2} \\
\text { increased significantly in the rural area while the age- } \\
\text { standardized prevalence of central obesity increased } \\
\text { significantly in the urban population ( }+32 \% \text { for women } \\
\text { and }+190 \% \text { for men) and it persisted after adjustments }\end{array}$ \\
\hline
\end{tabular}




\begin{tabular}{|c|c|c|c|}
\hline Author (year) & Determining variables measured & Obesity specification & Findings \\
\hline & & $\begin{array}{l}\left.29.99 \mathrm{~kg} / \mathrm{m}^{2}\right) \\
\text { Obese }\left(\geq 30 \mathrm{~kg} / \mathrm{m}^{2}\right) \\
\text { Central obesity: } W C \geq 80 \mathrm{~cm} \\
\text { for women and } 94 \mathrm{~cm} \text { for men }\end{array}$ & $\begin{array}{l}\text { for age group, alcohol consumption, tobacco smoking, } \\
\text { and level of education. }\end{array}$ \\
\hline $\begin{array}{l}\text { Goryakin et al. } \\
\text { (2015) }\end{array}$ & $\begin{array}{l}\text { Social globalization } \\
\text { Political globalization } \\
\text { Economic globalization } \\
\text { Education } \\
\text { Occupation } \\
\text { Age } \\
\text { Number of children }\end{array}$ & $\begin{array}{l}\text { BMI: (Underweight } \\
<18.50 \mathrm{~kg} / \mathrm{m}^{2} \\
\text { Normal range (18.5- } \\
\left.24.99 \mathrm{~kg} / \mathrm{m}^{2}\right) \\
\text { Overweight }(25.00- \\
\left.29.99 \mathrm{~kg} / \mathrm{m}^{2}\right) \\
\text { Obese }\left(\geq 30 \mathrm{~kg} / \mathrm{m}^{2}\right) .\end{array}$ & $\begin{array}{l}\text { Economic globalization quartile } 2(r=0.117, p=0.003) \text {, } \\
\text { economic globalization quartile } 3(r=0.147, p=0.003) \\
\text { and economic globalization quartile } 4(r=0.139, p \\
=0.003) \text { were significantly associated with overweight } \\
\text { in women. }\end{array}$ \\
\hline $\begin{array}{l}\text { Grey et al. } \\
(2006)\end{array}$ & $\begin{array}{l}\text { Socio-economic status } \\
\text { Educational level } \\
\text { Healthy lifestyle score }\end{array}$ & $\begin{array}{l}\text { BMI: (Underweight } \\
<18.50 \mathrm{~kg} / \mathrm{m}^{2} \\
\text { Normal range (18.5- }\end{array}$ & $\begin{array}{l}\text { fat-free mass }(\mathrm{kg}) \text { was } \\
\text { significantly higher in males than females }\end{array}$ \\
\hline
\end{tabular}




\begin{tabular}{|c|c|c|c|}
\hline Author (year) & Determining variables measured & Obesity specification & Findings \\
\hline & Western influences & $\begin{array}{l}\left.24.99 \mathrm{~kg} / \mathrm{m}^{2}\right) \\
\text { Overweight }(25.00 \text { - } \\
\left.29.99 \mathrm{~kg} / \mathrm{m}^{2}\right) \\
\text { Obese }\left(\geq 30 \mathrm{~kg} / \mathrm{m}^{2}\right)\end{array}$ & \\
\hline $\begin{array}{l}\text { Koussoh et al. } \\
\text { (2019) }\end{array}$ & $\begin{array}{l}\text { Physical activity } \\
\text { Blood pressure Education level } \\
\text { Socioeconomic level } \\
\text { Age } \\
\text { Marital status }\end{array}$ & $\begin{array}{l}\text { BMI: (Underweight } \\
<18.50 \mathrm{~kg} / \mathrm{m}^{2} \\
\text { Normal range (18.5- } \\
\left.24.99 \mathrm{~kg} / \mathrm{m}^{2}\right) \\
\text { Overweight }(25.00- \\
\left.29.99 \mathrm{~kg} / \mathrm{m}^{2}\right) \\
\text { Obese }\left(\geq 30 \mathrm{~kg} / \mathrm{m}^{2}\right) .\end{array}$ & $\begin{array}{l}\text { Age }(p=0.006) \text {, marital status ( } p=0.002) \text { and blood } \\
\text { pressure }(p=0.004) \text { were significantly associated with } \\
\text { obesity. }\end{array}$ \\
\hline $\begin{array}{l}\text { Lartey et al. } \\
\text { (2019) }\end{array}$ & $\begin{array}{l}\text { Age } \\
\text { Sex } \\
\text { Education level }\end{array}$ & $\begin{array}{l}\text { BMI: (Underweight } \\
<18.50 \mathrm{~kg} / \mathrm{m}^{2} \\
\text { Normal range }(18.5-\end{array}$ & $\begin{array}{l}\text { Not meeting the recommended physical activity level } \\
\text { among females was associated with higher odds of } \\
\text { obesity (OR }=3.23 ; 95 \% \mathrm{Cl}: 1.13-6.23 \text { ) and high central }\end{array}$ \\
\hline
\end{tabular}




\begin{tabular}{|c|c|c|c|}
\hline Author (year) & Determining variables measured & Obesity specification & Findings \\
\hline & $\begin{array}{l}\text { Marital status } \\
\text { Residence/location } \\
\text { Household wealth } \\
\text { smoking status } \\
\text { alcohol consumption } \\
\text { Fruit and vegetable intake } \\
\text { Physical activity }\end{array}$ & $\begin{array}{l}\left.24.99 \mathrm{~kg} / \mathrm{m}^{2}\right) \text { Overweight } \\
\left(25.00-29.99 \mathrm{~kg} / \mathrm{m}^{2}\right) \\
\text { Obese }\left(\geq 30 \mathrm{~kg} / \mathrm{m}^{2}\right) . \\
\text { Waist circumference and high } \\
\text { central adiposity (determined } \\
\text { using sub-Saharan Africa } \\
\text { standards }\end{array}$ & adiposity (OR $=2.19 ; 95 \% \mathrm{Cl}: 1.32-3.63)$. \\
\hline $\begin{array}{l}\text { Luke et al. } \\
\text { (2014) }\end{array}$ & $\begin{array}{l}\text { Physical activity } \\
\text { Age } \\
\text { Gender } \\
\text { Employment } \\
\text { Education } \\
\text { Participant and significant other's } \\
\text { occupation } \\
\text { Parental education }\end{array}$ & $\begin{array}{l}\text { BMI: (Underweight } \\
<18.50 \mathrm{~kg} / \mathrm{m}^{2} \\
\text { Normal range }(18.5- \\
\left.24.99 \mathrm{~kg} / \mathrm{m}^{2}\right) \\
\text { Overweight }(25.00- \\
\left.29.99 \mathrm{~kg} / \mathrm{m}^{2}\right) \\
\text { Obese }\left(\geq 30 \mathrm{~kg} / \mathrm{m}^{2}\right) .\end{array}$ & $\begin{array}{l}\text { In the ecological analysis time spent in moderate-to- } \\
\text { vigorous activity was inversely associated with BMI } \\
\text { (r[?]=0.71), and inversely associated with waist } \\
\text { circumference in Ghana }(r=-0.15) \text {. }\end{array}$ \\
\hline
\end{tabular}




\begin{tabular}{|c|c|c|c|}
\hline Author (year) & Determining variables measured & Obesity specification & Findings \\
\hline & Household assets and amenities. & & \\
\hline $\begin{array}{l}\text { Macia et al. } \\
\text { (2010) }\end{array}$ & $\begin{array}{l}\text { Age } \\
\text { Gender } \\
\text { Marital status } \\
\text { Education level } \\
\text { Ethnicity }\end{array}$ & $\begin{array}{l}\text { BMI: (Underweight } \\
<18.50 \mathrm{~kg} / \mathrm{m}^{2} \\
\text { Normal range (18.5- } \\
24.99 \mathrm{~kg} / \mathrm{m}^{2} \text { ) } \\
\text { Overweight ( } 25.00- \\
\left.29.99 \mathrm{~kg} / \mathrm{m}^{2}\right) \\
\text { Obese }\left(\geq 30 \mathrm{~kg} / \mathrm{m}^{2}\right) . \\
\text { Waist circumference (WC) } \geq 80 \\
\text { cm for women and } 94 \mathrm{~cm} \text { for } \\
\text { men } \\
\text { Waist to Hip ratio (WHR) }\end{array}$ & $\begin{array}{l}\text { Ages } 30-39 \text { (OR 8.02, } \mathrm{Cl} 3.57-18.02, \mathrm{P}<0.001), 40- \\
49(\mathrm{OR}=22.51, \mathrm{Cl}=8.88-57.06, \mathrm{P}<0.001) \text { and } \geq 50(\mathrm{OR} \\
=24.4, \mathrm{Cl}=9.03-65.91, \mathrm{P}<0.001) \text { were significantly } \\
\text { associated with obesity compared to age } 20-29 \text {. } \\
\text { Female was also significantly associated with obesity } \\
\text { (OR }=17.91, \mathrm{Cl}=9.39-34.15, \mathrm{P}<0.001) \text { compared to } \\
\text { male. }\end{array}$ \\
\hline $\begin{array}{l}\text { Chidozie et al. } \\
\text { (2009) }\end{array}$ & Socioeconomic strata & $\begin{array}{l}\text { BMI: (Underweight } \\
<18.50 \mathrm{~kg} / \mathrm{m}^{2} \\
\text { Normal range (18.5- }\end{array}$ & SES was found to be inversely related $(p<0.010) \mathrm{BMI}$ \\
\hline
\end{tabular}




\begin{tabular}{|c|c|c|c|}
\hline Author (year) & Determining variables measured & Obesity specification & Findings \\
\hline & & $\begin{array}{l}\left.24.99 \mathrm{~kg} / \mathrm{m}^{2}\right) \\
\text { Overweight }(25.00- \\
\left.29.99 \mathrm{~kg} / \mathrm{m}^{2}\right) \\
\text { Obese }\left(\geq 30 \mathrm{~kg} / \mathrm{m}^{2}\right)\end{array}$ & \\
\hline $\begin{array}{l}\text { Mogre et al. } \\
(2015)\end{array}$ & $\begin{array}{l}\text { Age } \\
\text { Sex } \\
\text { Food group } \\
\text { Physical activity }\end{array}$ & $\begin{array}{l}\text { BMI: (Underweight } \\
<18.50 \mathrm{~kg} / \mathrm{m}^{2} \\
\text { Normal range (18.5- } \\
24.99 \mathrm{~kg} / \mathrm{m}^{2} \text { ) } \\
\text { Overweight ( } 25.00- \\
\left.29.99 \mathrm{~kg} / \mathrm{m}^{2}\right) \\
\text { Obese }\left(\geq 30 \mathrm{~kg} / \mathrm{m}^{2}\right) . \\
\text { Waist to Hip Ratio (WHR): } 0.9 \\
\text { or less in men and } 0.85 \text { or less } \\
\text { in women. }\end{array}$ & 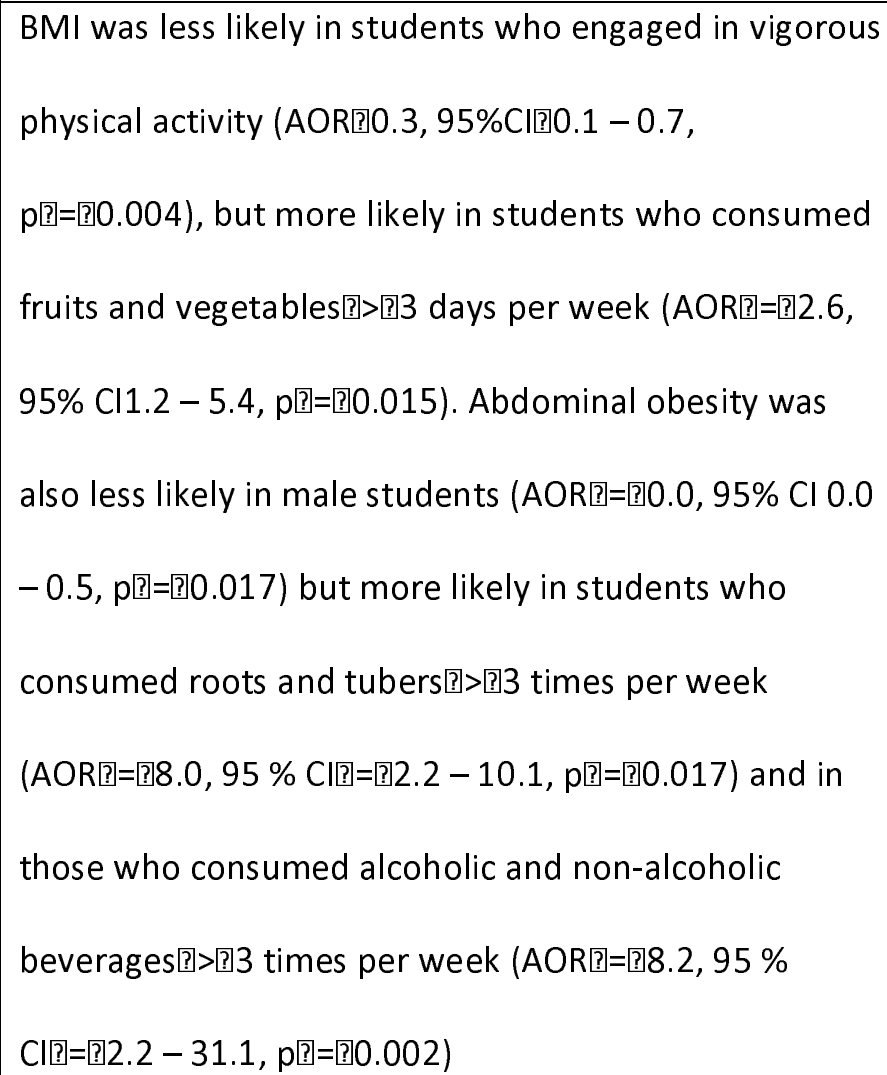 \\
\hline
\end{tabular}




\begin{tabular}{|c|c|c|c|}
\hline Author (year) & Determining variables measured & Obesity specification & Findings \\
\hline $\begin{array}{l}\text { Neupane et al. } \\
\text { (2016) }\end{array}$ & $\begin{array}{l}\text { Place of residence } \\
\text { Socio-economic Status } \\
\text { Maternal education }\end{array}$ & $\begin{array}{l}\text { BMI: (Underweight } \\
<18.50 \mathrm{~kg} / \mathrm{m}^{2} \\
\text { Normal range }(18.5- \\
\left.24.99 \mathrm{~kg} / \mathrm{m}^{2}\right) \\
\text { Overweight }(25.00- \\
\left.29.99 \mathrm{~kg} / \mathrm{m}^{2}\right) \\
\text { Obese }\left(\geq 30 \mathrm{~kg} / \mathrm{m}^{2}\right)\end{array}$ & $\begin{array}{l}\text { The women in urban residence and those who were } \\
\text { classified as rich, with respect to the quintile of the } \\
\text { wealth index, had higher likelihood of overweight and } \\
\text { obesity. In the pooled results, high education was } \\
\text { significantly associated with overweight and obesity. }\end{array}$ \\
\hline $\begin{array}{l}\text { Ngianga-Bakwin } \\
\text { \& Saverio (2014) }\end{array}$ & $\begin{array}{l}\text { Geographic location } \\
\text { Age Education level } \\
\text { Religion } \\
\text { Wealth index Ethnicity } \\
\text { Place of residence }\end{array}$ & $\begin{array}{l}\text { BMI: (Underweight } \\
<18.50 \mathrm{~kg} / \mathrm{m}^{2} \\
\text { Normal range }(18.5- \\
\left.24.99 \mathrm{~kg} / \mathrm{m}^{2}\right) \\
\text { Overweight }(25.00- \\
\left.29.99 \mathrm{~kg} / \mathrm{m}^{2}\right) \\
\text { Obese }\left(\geq 30 \mathrm{~kg} / \mathrm{m}^{2}\right)\end{array}$ & $\begin{array}{l}\text { Higher education level (OR } 1.68 \text { and } 95 \% \text { credible } \\
\text { region (CR) } 1.38-2.00 \text { ), higher wealth index (OR } 3.45 \text {, } \\
\text { CR } 2.98-4.05 \text { ), living in urban settings (OR }=1.24, C R \\
=1.14-1.36 \text { ) were significantly associated with higher } \\
\text { prevalence of obesity. }\end{array}$ \\
\hline $\begin{array}{l}\text { Nonterah et al. } \\
\text { (2017) }\end{array}$ & $\begin{array}{l}\text { Age groups in years } \\
\text { Ethnicity }\end{array}$ & $\begin{array}{l}\text { BMI: (Underweight } \\
<18.50 \mathrm{~kg} / \mathrm{m}^{2}\end{array}$ & $\begin{array}{l}\text { Participants with the highest level of education and a } \\
\text { high household socio-economic status had higher BMIs }\end{array}$ \\
\hline
\end{tabular}




\begin{tabular}{|c|c|c|c|}
\hline Author (year) & Determining variables measured & Obesity specification & Findings \\
\hline & $\begin{array}{l}\text { Partnership status } \\
\text { Highest level of education } \\
\text { Employment status } \\
\text { People-to-bedroom density } \\
\text { Household SES categories }\end{array}$ & $\begin{array}{l}\text { Normal range (18.5- } \\
\left.24.99 \mathrm{~kg} / \mathrm{m}^{2}\right) \\
\text { Overweight }(25.00- \\
\left.29.99 \mathrm{~kg} / \mathrm{m}^{2}\right) \\
\text { Obese }\left(\geq 30 \mathrm{~kg} / \mathrm{m}^{2}\right) .\end{array}$ & $\begin{array}{l}\text { than those in the lowest strata in both men } \\
(\beta=0.074, p=0.028 \text { and } \beta=0.072, p<0.001 \text {, } \\
\text { respectively) and women ( } \beta=0.174, p=0.001 \text { and } \\
\beta=0.109, p<0.001 \text {, respectively). Men } \\
(\beta=-0.050 ; p<0.001) \text { and women } \\
\text { ( } \beta=-0.073 ; p<0.001) \text { of the Nankana ethnic group had } \\
\text { a lower BMI than the Kassena ethnic group. Among } \\
\text { men, alcohol consumption ( } \beta=-0.021 ; p=0.001) \text { and } \\
\text { smoking ( } \beta=-0.216 ; p<0.001) \text { were associated with } \\
\text { lower BMI. Smokeless tobacco was associated with } \\
\text { lower BMI among women. Pesticide exposure was } \\
\text { associated with higher BMI ( } \beta=0.022 ; p=0.022) \\
\text { among men }\end{array}$ \\
\hline $\begin{array}{l}\text { Nuertey et al. } \\
\text { (2017) }\end{array}$ & $\begin{array}{l}\text { Sex } \\
\text { Age } \\
\text { Marital status }\end{array}$ & $\begin{array}{l}\text { BMI: (Underweight } \\
<18.50 \mathrm{~kg} / \mathrm{m}^{2} \\
\text { Normal range }(18.5-\end{array}$ & $\begin{array}{l}\text { Hypertensive pensioners had } 2.6 \text { times odds of being } \\
\text { obese compared to non-hypertensive pensioners } \\
(95 \% \mathrm{Cl} 2.3-2.9) \text {. Diabetics were associated with higher }\end{array}$ \\
\hline
\end{tabular}




\begin{tabular}{|c|c|c|c|}
\hline Author (year) & Determining variables measured & Obesity specification & Findings \\
\hline & $\begin{array}{l}\text { Ethnicity } \\
\text { Education level } \\
\text { Social class } \\
\text { Region of residence } \\
\text { Religion } \\
\text { Hypertension } \\
\text { Diabetes }\end{array}$ & $\begin{array}{l}\left.24.99 \mathrm{~kg} / \mathrm{m}^{2}\right) \\
\text { Overweight }(25.00- \\
\left.29.99 \mathrm{~kg} / \mathrm{m}^{2}\right) \\
\text { Obese }\left(\geq 30 \mathrm{~kg} / \mathrm{m}^{2}\right)\end{array}$ & $\begin{array}{l}\text { odds of being obese (OR } 2.595 \% \mathrm{Cl} 2.0-2.0 \text { ) compared } \\
\text { to non-diabetics. Female pensioners were associated } \\
\text { with three times the odds of being obese compared to } \\
\text { the male pensioners }\end{array}$ \\
\hline $\begin{array}{l}\text { Chinedu et al. } \\
\text { (2017) }\end{array}$ & $\begin{array}{l}\text { Age } \\
\text { Sex }\end{array}$ & $\begin{array}{l}\text { BMI: (Underweight } \\
<18.50 \mathrm{~kg} / \mathrm{m}^{2} \\
\text { Normal range (18.5- } \\
\left.24.99 \mathrm{~kg} / \mathrm{m}^{2}\right) \\
\text { Overweight }(25.00- \\
\left.29.99 \mathrm{~kg} / \mathrm{m}^{2}\right) \\
\text { Obese }\left(\geq 30 \mathrm{~kg} / \mathrm{m}^{2}\right)\end{array}$ & $\begin{array}{l}\text { Age }(r=0.612, p=0.000) \text { was significantly associated } \\
\text { with BMI of the subjects. }\end{array}$ \\
\hline $\begin{array}{l}\text { Obirikorang et } \\
\text { al. (2016) }\end{array}$ & $\begin{array}{l}\text { Physical activity } \\
\text { Alcohol intake }\end{array}$ & $\begin{array}{l}\text { BMI: (Underweight } \\
<18.50 \mathrm{~kg} / \mathrm{m}^{2}\end{array}$ & $\begin{array}{l}\text { Taking meals late at night (OR } 2.595 \% \mathrm{Cl} 1.1-5.7 \\
\mathrm{p}=0.0398)\end{array}$ \\
\hline
\end{tabular}




\begin{tabular}{|c|c|c|c|}
\hline Author (year) & Determining variables measured & Obesity specification & Findings \\
\hline & Working under stressful hours & $\begin{array}{l}\text { Normal range (18.5- } \\
\left.24.99 \mathrm{~kg} / \mathrm{m}^{2}\right) \\
\text { Overweight }(25.00- \\
\left.29.99 \mathrm{~kg} / \mathrm{m}^{2}\right) \\
\text { Obese }\left(\geq 30 \mathrm{~kg} / \mathrm{m}^{2}\right)\end{array}$ & $\begin{array}{l}\text { taking meals at stressful hours [OR=7.9 ( } 2.1 \text { to } 29.8) \text {; } \\
p=0.0009] \text {, and fast-food intake [OR=2.6 (1.1 to } 6.0 \text { ), } \\
p=0.0370 \text { ) were independent risk factors of obesity } \\
\text { classified by BMI. }\end{array}$ \\
\hline $\begin{array}{l}\text { Obirikorang et } \\
\text { al. (2015) }\end{array}$ & $\begin{array}{l}\text { Biochemical Assays } \\
\text { measurements } \\
\text { Blood pressure } \\
\text { Occupation } \\
\text { Type of family }\end{array}$ & $\begin{array}{l}\text { BMI: (Underweight } \\
<18.50 \mathrm{~kg} / \mathrm{m}^{2} \\
\text { Normal range (18.5- } \\
\left.24.99 \mathrm{~kg} / \mathrm{m}^{2}\right) \\
\text { Overweight }(25.00- \\
\left.29.99 \mathrm{~kg} / \mathrm{m}^{2}\right) \\
\text { Obese }\left(\geq 30 \mathrm{~kg} / \mathrm{m}^{2}\right) \\
\text { Percentage body fat (BF\%) } \\
\text { estimated using Adult body } \\
\text { fat\% }=(1.20 \times \text { BMI) +(0.23 } \times\end{array}$ & $\begin{array}{l}\text { Obesity risk factors by urban / rural residence remained } \\
\text { significant after adjusting for gender and age }\end{array}$ \\
\hline
\end{tabular}




\begin{tabular}{|c|c|c|c|}
\hline Author (year) & Determining variables measured & Obesity specification & Findings \\
\hline & & Age) $-(10.8 \times$ sex $)-5.4$. & \\
\hline Okoh (2013) & $\begin{array}{l}\text { Ethnicity } \\
\text { Educational status } \\
\text { Marriage status } \\
\text { Frequency of watching television }\end{array}$ & $\begin{array}{l}\text { BMI: (Underweight } \\
<18.50 \mathrm{~kg} / \mathrm{m}^{2} \\
\text { Normal range }(18.5- \\
\left.24.99 \mathrm{~kg} / \mathrm{m}^{2}\right) \\
\text { Overweight }(25.00- \\
\left.29.99 \mathrm{~kg} / \mathrm{m}^{2}\right) \\
\text { Obese }\left(\geq 30 \mathrm{~kg} / \mathrm{m}^{2}\right)\end{array}$ & $\begin{array}{l}\text { Results showed increased frequency of watching } \\
\text { television, belonging to a particular ethnic group, } \\
\text { having a tertiary education and increased parity as risk } \\
\text { factors for increased BMI. }\end{array}$ \\
\hline $\begin{array}{l}\text { Olatunbosun et } \\
\text { al. (2010) }\end{array}$ & $\begin{array}{l}\text { Age } \\
\text { Gender } \\
\text { Marital status } \\
\text { Salary grade } \\
\text { Physical activity } \\
\text { Smoking } \\
\text { Alcohol } \\
\text { Family history of hypertension }\end{array}$ & $\begin{array}{l}\text { BMI: (Underweight } \\
<18.50 \mathrm{~kg} / \mathrm{m}^{2} \\
\text { Normal range (18.5- } \\
\left.24.99 \mathrm{~kg} / \mathrm{m}^{2}\right) \\
\text { Overweight }(25.00- \\
\left.29.99 \mathrm{~kg} / \mathrm{m}^{2}\right) \\
\text { Obese }\left(\geq 30 \mathrm{~kg} / \mathrm{m}^{2}\right)\end{array}$ & $\begin{array}{l}\text { Higher salary grade levels ( } O R=6.67, p=0.001) \text {, alcohol } \\
\text { use } \geq 60 \mathrm{~g} / \text { week ( } O R=2.78, p=0.001 \text { ), family history of } \\
\text { diabetes ( } O R=0.38, p=0.001 \text { ) and hypertension ( } O R \\
=2.68, p=0.001 \text { ) were predictive of obesity and } \\
\text { overweight in men. Only age ( } O R=1.04, p=0.008 \text { ) and } \\
\text { higher salary grade levels ( } O R=4.13, p=0.002 \text { ) were } \\
\text { predictive of obesity and overweight for women. }\end{array}$ \\
\hline
\end{tabular}




\begin{tabular}{|c|c|c|c|}
\hline Author (year) & Determining variables measured & Obesity specification & Findings \\
\hline & Family history of diabetes & & \\
\hline $\begin{array}{l}\text { Ajayi et al. } \\
\text { (2016) }\end{array}$ & $\begin{array}{l}\text { Smoking habit } \\
\text { Education } \\
\text { Gender } \\
\text { Age } \\
\text { Marital status }\end{array}$ & $\begin{array}{l}\text { BMI: (Underweight } \\
<18.50 \mathrm{~kg} / \mathrm{m}^{2} \\
\text { Normal range }(18.5- \\
\left.24.99 \mathrm{~kg} / \mathrm{m}^{2}\right) \\
\text { Overweight }(25.00- \\
\left.29.99 \mathrm{~kg} / \mathrm{m}^{2}\right) \\
\text { Obese }\left(\geq 30 \mathrm{~kg} / \mathrm{m}^{2}\right)\end{array}$ & $\begin{array}{l}\text { Female sex was a predictor of overweight and obesity } \\
\text { (combined) in peri-urban Uganda [AOR }=8.01 ; 95 \% \mathrm{Cl} \text { : } \\
4.02,15.96 \text { ) and obesity in rural Uganda [AOR }=11.22 \text {; } \\
95 \% \mathrm{Cl}: 2.27,55.40 \text { ), peri-urban Uganda [AOR }=27.80 \text {; } \\
95 \% \mathrm{Cl}: 7.13,108.41 \text { ) and } \mathrm{SA} \text { [AOR }=2.17 ; 95 \% \mathrm{Cl} \text { : } \\
1.19,4.00 \text { ). Increasing age was a predictor of } \mathrm{BMI}>=25 \\
\mathrm{~kg} / \mathrm{m} 2 \text { in Nigeria [Age > }=45-\mathrm{AOR}=9.11 ; 95 \% \mathrm{Cl}: 1.72 \text {, } \\
48.16 \text { ] and SA [AOR = 6.22; } 95 \% \mathrm{Cl}: 2.75,14.07], \text { while } \\
\text { marital status was predictor of } \mathrm{BMI}>=25 \mathrm{~kg} / \mathrm{m} 2 \text { only in } \\
\text { peri-urban Uganda. [Married - } \mathrm{AOR}=4.49 ; 95 \% \mathrm{Cl} \text { : } \\
1.74,11.57 \text { ]. }\end{array}$ \\
\hline $\begin{array}{l}\text { Osayomi \& } \\
\text { Orhiere (2017) }\end{array}$ & $\begin{array}{l}\text { Sex } \\
\text { Age } \\
\text { Occupation }\end{array}$ & $\begin{array}{l}\text { BMI: (Underweight } \\
<18.50 \mathrm{~kg} / \mathrm{m}^{2} \\
\text { Normal range }(18.5-\end{array}$ & $\begin{array}{l}\text { Physical proximity to fast food outlets was the only } \\
\text { significant factor driving the spatial pattern of obesity } \\
(b=0.645 ; R 2=0.416) \text {. }\end{array}$ \\
\hline
\end{tabular}




\begin{tabular}{|c|c|c|c|}
\hline Author (year) & Determining variables measured & Obesity specification & Findings \\
\hline & $\begin{array}{l}\text { Education status } \\
\text { Ethnicity } \\
\text { Marital status } \\
\text { Household and neighbourhood } \\
\text { characteristics (spatial risk factors) }\end{array}$ & $\begin{array}{l}\left.24.99 \mathrm{~kg} / \mathrm{m}^{2}\right) \\
\text { Overweight }(25.00- \\
\left.29.99 \mathrm{~kg} / \mathrm{m}^{2}\right) \\
\text { Obese }\left(\geq 30 \mathrm{~kg} / \mathrm{m}^{2}\right)\end{array}$ & \\
\hline $\begin{array}{l}\text { Oue'draogo et } \\
\text { al. (2008) }\end{array}$ & $\begin{array}{l}\text { Dietary practices } \\
\text { Lifestyles }\end{array}$ & $\begin{array}{l}\text { BMI: (Underweight } \\
<18.50 \mathrm{~kg} / \mathrm{m}^{2} \\
\text { Normal range }(18.5- \\
\left.24.99 \mathrm{~kg} / \mathrm{m}^{2}\right) \\
\text { Overweight }(25.00- \\
\left.29.99 \mathrm{~kg} / \mathrm{m}^{2}\right) \\
\text { Obese }\left(\geq 30 \mathrm{~kg} / \mathrm{m}^{2}\right)\end{array}$ & $\begin{array}{l}\text { After adjustment for these factors, obesity remained } \\
\text { associated with the area of residence: residents from } \\
\text { SHBD areas were more likely to be obese than those } \\
\text { from ULBD areas (OR=51.41; } 95 \% \mathrm{Cl} 2.59,4.76\end{array}$ \\
\hline $\begin{array}{l}\text { Oyebisi \& } \\
\text { Olumakaiye ( }\end{array}$ & $\begin{array}{l}\text { Age Sex } \\
\text { Education Base } \\
\text { Length of stay in school } \\
\text { Upkeep allowance }\end{array}$ & $\begin{array}{l}\text { BMI: (Underweight } \\
<18.50 \mathrm{~kg} / \mathrm{m}^{2} \\
\text { Normal range }(18.5- \\
\left.24.99 \mathrm{~kg} / \mathrm{m}^{2}\right)\end{array}$ & $\begin{array}{l}\text { There was a significant relationship between fast food } \\
\text { consumption and obesity ( } r=0.47, p=0.0001 \text { ). }\end{array}$ \\
\hline
\end{tabular}




\begin{tabular}{|c|c|c|c|}
\hline Author (year) & Determining variables measured & Obesity specification & Findings \\
\hline & Fast food consumption & $\begin{array}{l}\text { Overweight }(25.00- \\
\left.29.99 \mathrm{~kg} / \mathrm{m}^{2}\right) \\
\text { Obese }\left(\geq 30 \mathrm{~kg} / \mathrm{m}^{2}\right) .\end{array}$ & \\
\hline $\begin{array}{l}\text { Oyeyemi et al. } \\
\text { (2013) }\end{array}$ & $\begin{array}{l}\text { Physical Activity and Sitting Time } \\
\text { Environmental Assessment. } \\
\text { Socio-demographic Characteristics }\end{array}$ & $\begin{array}{l}\text { BMI: (Underweight } \\
<18.50 \mathrm{~kg} / \mathrm{m}^{2} \\
\text { Normal range (18.5- } \\
\left.24.99 \mathrm{~kg} / \mathrm{m}^{2}\right) \\
\text { Overweight }(25.00- \\
\left.29.99 \mathrm{~kg} / \mathrm{m}^{2}\right) \\
\text { Obese }\left(\geq 30 \mathrm{~kg} / \mathrm{m}^{2}\right) .\end{array}$ & $\begin{array}{l}\text { Walking and total PA significantly mediated the } \\
\text { association between BMI and perception of higher } \\
\text { residential density (ab 1/4_.025 and_.037, respectively), } \\
\text { absence of garbage (ab 1/4_.046 and_.076, respectively), } \\
\text { and more safety from crime at night (ab 1/4_.044 and } \\
\text { _.083, respectively). In addition, walking, moderate to } \\
\text { vigorous PA, and total PA significantly mediated the } \\
\text { association between BMI and perception of better } \\
\text { aesthetics (ab 1/4_.035,_.022, and_.071, respectively). }\end{array}$ \\
\hline $\begin{array}{l}\text { Oyeyemi \& } \\
\text { Adegoke (2012) }\end{array}$ & $\begin{array}{l}\text { Age, gender, marital status, ethnic } \\
\text { group, educational level, } \\
\text { employment status, monthly } \\
\text { income (naira). }\end{array}$ & $\begin{array}{l}\text { BMI: (Underweight } \\
<18.50 \mathrm{~kg} / \mathrm{m}^{2} \\
\text { Normal range }(18.5- \\
\left.24.99 \mathrm{~kg} / \mathrm{m}^{2}\right)\end{array}$ & $\begin{array}{l}\text { After adjustment for sociodemographic variables, } \\
\text { overweight was associated with distant access to } \\
\text { commercial facilities (OR } 1.49 ; 95 \% \mathrm{Cl} 1.02-2.18 \text { ), poor } \\
\text { neighbourhood aesthetics (OR1.58; } 95 \% \mathrm{Cl} 1.16-2.09 \text { ), }\end{array}$ \\
\hline
\end{tabular}




\begin{tabular}{|c|c|c|c|}
\hline Author (year) & Determining variables measured & Obesity specification & Findings \\
\hline & $\begin{array}{l}\text { Residential density, Access to } \\
\text { commercial places, Access to non- } \\
\text { residential places, Access to public } \\
\text { transport, Presence of } \\
\text { recreational centres, Presence of } \\
\text { pedestrian pathways, } \\
\text { Maintenance of pathways, } \\
\text { Presence of beautiful things, } \\
\text { Absence of unattended animals, } \\
\text { Absence of garbage and foul } \\
\text { odours, Seeing people active, } \\
\text { Connectivity of street, Traffic } \\
\text { safety for bicycling, Traffic safety } \\
\text { for walking, Crime Safety during } \\
\text { the day, Crime safety at night. }\end{array}$ & $\begin{array}{l}\text { Overweight }(25.00- \\
\left.29.99 \mathrm{~kg} / \mathrm{m}^{2}\right) \\
\text { Obese }\left(\geq 30 \mathrm{~kg} / \mathrm{m}^{2}\right)\end{array}$ & $\begin{array}{l}\text { perceiving garbage and offensive odours in the } \\
\text { neighbourhood (OR } 1.4195 \% \mathrm{Cl} 1.05-1.89 \text { ) and feeling } \\
\text { unsafe from crime at night (OR } 1.47 ; 95 \% \mathrm{Cl} 1.13-1.91 \text { ) } \\
\text { and unsafe from traffic (OR } 1.56 ; 95 \% \mathrm{Cl} 1.17-2.07 \text { ) in } \\
\text { the total sample. Low residential density (OR1.39; } \\
95 \% \mathrm{Cl} 1.02-1.93 \text { ) and poorly maintained pedestrian } \\
\text { pathways (OR 1.89; } 95 \% \mathrm{Cl} 1.13-3.17 \text { ) associated with } \\
\text { overweight in men only, and absence of beautiful } \\
\text { things (OR } 2.23 \text {; } 95 \% \mathrm{Cl}, 1.42-3.50 \text { ) and high traffic } \\
\text { making it unsafe to walk (OR, 2.39; } 95 \% \mathrm{Cl}, 1.49-3.83 \text { ) } \\
\text { associated with overweight in women only }\end{array}$ \\
\hline
\end{tabular}




\begin{tabular}{|c|c|c|c|}
\hline Author (year) & Determining variables measured & Obesity specification & Findings \\
\hline $\begin{array}{l}\text { Pasquet et al. } \\
\text { (2003) }\end{array}$ & $\begin{array}{l}\text { Sex } \\
\text { Age } \\
\text { Education level } \\
\text { Occupation length of residence in } \\
\text { Yaoundé } \\
\text { Ethnicity } \\
\text { Parity } \\
\text { Smoking practice } \\
\text { Physical activity pattern }\end{array}$ & $\begin{array}{l}\text { BMI: (Underweight } \\
<18.50 \mathrm{~kg} / \mathrm{m}^{2} \\
\text { Normal range }(18.5- \\
\left.24.99 \mathrm{~kg} / \mathrm{m}^{2}\right) \\
\text { Overweight }(25.00- \\
\left.29.99 \mathrm{~kg} / \mathrm{m}^{2}\right) \\
\text { Obese }\left(\geq 30 \mathrm{~kg} / \mathrm{m}^{2}\right)\end{array}$ & $\begin{array}{l}\text { The length of residence in Yaoundé }(\mathrm{OR}=2.0,95 \% \mathrm{Cl}= \\
1.1-3.8) \text { increasing education level }(\mathrm{OR}=2.7,95 \% \mathrm{Cl}= \\
1.3-5.6) \text {, occupation }(\mathrm{OR}=1.9,95 \% \mathrm{Cl}=1.1-3.6) \text {, } \\
\text { ethnicity }(\mathrm{OR}=2.4,95 \% \mathrm{Cl}=1.3-4.4) \text {, physical inactivity } \\
(\mathrm{OR}=1.5,95 \% \mathrm{Cl}=1.1-2.2) \text { and smoking practices (OR } \\
=0.5,95 \% \mathrm{Cl}=0.3-0.8) \text { influence early overweight } \\
\text { and/or obesity }\end{array}$ \\
\hline $\begin{array}{l}\text { Peltzer et al. } \\
\text { (2014) }\end{array}$ & $\begin{array}{l}\text { Age } \\
\text { Gender } \\
\text { Wealth } \\
\text { Country income classification } \\
\text { Organized religious activity } \\
\text { Social support }\end{array}$ & $\begin{array}{l}\text { BMI: (Underweight } \\
<18.50 \mathrm{~kg} / \mathrm{m}^{2} \\
\text { Normal range }(18.5- \\
\left.24.99 \mathrm{~kg} / \mathrm{m}^{2}\right) \\
\text { Overweight }(25.00- \\
\left.29.99 \mathrm{~kg} / \mathrm{m}^{2}\right)\end{array}$ & $\begin{array}{l}\text { Females who are } 22 y e a r s \text { or more are significantly } \\
\text { associated with obesity ( } \mathrm{AOR}=1.38, \mathrm{Cl}: 1.18-1.60) \text {. } \\
\text { Female in high organized religious activity are } \\
\text { significantly associated with overweight and obesity } \\
(\mathrm{AOR}=1.22, \mathrm{Cl}=1.03-1.47)\end{array}$ \\
\hline
\end{tabular}




\begin{tabular}{|c|c|c|c|}
\hline Author (year) & Determining variables measured & Obesity specification & Findings \\
\hline & $\begin{array}{l}\text { Dietary variables } \\
\text { Health risk behaviour }\end{array}$ & Obese $\left(\geq 30 \mathrm{~kg} / \mathrm{m}^{2}\right)$. & \\
\hline $\begin{array}{l}\text { Ramsay et al. } \\
\text { (2009) }\end{array}$ & $\begin{array}{l}\text { Age } \\
\text { sex } \\
\text { ethnicity } \\
\text { socio-economic status } \\
\text { household crowding } \\
\text { education level } \\
\text { marital status } \\
\text { physical activity } \\
\text { sedentary time } \\
\text { night-time sleep duration } \\
\text { smoking } \\
\text { use of smokeless tobacco } \\
\text { dietary intake }\end{array}$ & $\begin{array}{l}\text { BMI: (Underweight } \\
<18.50 \mathrm{~kg} / \mathrm{m}^{2} \\
\text { Normal range (18.5- } \\
\left.24.99 \mathrm{~kg} / \mathrm{m}^{2}\right) \\
\text { Overweight }(25.00- \\
\left.29.99 \mathrm{~kg} / \mathrm{m}^{2}\right) \\
\text { Obese }\left(\geq 30 \mathrm{~kg} / \mathrm{m}^{2}\right)\end{array}$ & $\begin{array}{l}\text { Across Navrongo }\left(R^{2}=0.20\right) \text { and Nanoro }\left(R^{2}=0.20\right) \text {, } \\
\text { men with higher socioeconomic and educational leve } \\
\text { were associated with higher BMI. }\end{array}$ \\
\hline
\end{tabular}




\begin{tabular}{|c|c|c|c|}
\hline Author (year) & Determining variables measured & Obesity specification & Findings \\
\hline & $\begin{array}{l}\text { alcohol intake } \\
\text { pesticide use } \\
\text { HIV and TB status } \\
\text { Parity } \\
\text { Menopausal stage }\end{array}$ & & \\
\hline $\begin{array}{l}\text { Razak et al. } \\
\text { (2015) }\end{array}$ & $\begin{array}{l}\text { Demographic variables } \\
\text { Socioeconomic variables }\end{array}$ & $\begin{array}{l}\text { BMI: (Underweight } \\
<18.50 \mathrm{~kg} / \mathrm{m}^{2} \\
\text { Normal range (18.5- } \\
\left.24.99 \mathrm{~kg} / \mathrm{m}^{2}\right) \\
\text { Overweight }(25.00- \\
\left.29.99 \mathrm{~kg} / \mathrm{m}^{2}\right) \\
\text { Obese }\left(\geq 30 \mathrm{~kg} / \mathrm{m}^{2}\right)\end{array}$ & $\begin{array}{l}\text { Increased risk of mortality among those with a BMI } \\
\text { lower than } 16 \mathrm{~kg} / \mathrm{m}^{2} \text { exceeds the increased risk } \\
\text { associated with being overweight or obesity. }\end{array}$ \\
\hline $\begin{array}{l}\text { Smith et al. } \\
\text { (2017) }\end{array}$ & $\begin{array}{l}\text { Age } \\
\text { Gender } \\
\text { ABO Blood groups }\end{array}$ & $\begin{array}{l}\text { BMI: (Underweight } \\
<18.50 \mathrm{~kg} / \mathrm{m}^{2} \\
\text { Normal range } 18.5-\end{array}$ & $\begin{array}{l}\text { No significant associations were found between the } \\
\text { determining variables and obesity }\end{array}$ \\
\hline
\end{tabular}




\begin{tabular}{|c|c|c|c|}
\hline Author (year) & Determining variables measured & Obesity specification & Findings \\
\hline & Rhesus factor & $\begin{array}{l}\left.24.99 \mathrm{~kg} / \mathrm{m}^{2}\right) \\
\text { Overweight }(25.00- \\
\left.29.99 \mathrm{~kg} / \mathrm{m}^{2}\right) \\
\text { Obese }\left(\geq 30 \mathrm{~kg} / \mathrm{m}^{2}\right) .\end{array}$ & \\
\hline $\begin{array}{l}\text { Sodjinou et al. } \\
\text { (2008) }\end{array}$ & $\begin{array}{l}\text { Diet quality score } \\
\text { Alcohol consumption score } \\
\text { Smoking score } \\
\text { Household amenities } \\
\text { Physical activity score }\end{array}$ & $\begin{array}{l}\text { BMI: (Underweight } \\
<18.50 \mathrm{~kg} / \mathrm{m}^{2} \\
\text { Normal range }(18.5- \\
\left.24.99 \mathrm{~kg} / \mathrm{m}^{2}\right) \\
\text { Overweight }(25.00- \\
\left.29.99 \mathrm{~kg} / \mathrm{m}^{2}\right) \\
\text { Obese }\left(\geq 30 \mathrm{~kg} / \mathrm{m}^{2}\right)\end{array}$ & $\begin{array}{l}\text { After controlling for age and sex, the odds of obesity } \\
\text { increased significantly with SES. } \\
\text { The likelihood of obesity decreased significantly as } \\
\text { while controlling for potential confounding factors. }\end{array}$ \\
\hline $\begin{array}{l}\text { Stringhini et al. } \\
(2016)\end{array}$ & $\begin{array}{l}\text { Smoking } \\
\text { Physical activity }\end{array}$ & $\begin{array}{l}\text { BMI: (Underweight } \\
<18.50 \mathrm{~kg} / \mathrm{m}^{2}\end{array}$ & Association between SES and obesity was direct \\
\hline
\end{tabular}




\begin{tabular}{|c|c|c|c|}
\hline Author (year) & Determining variables measured & Obesity specification & Findings \\
\hline & $\begin{array}{l}\text { Weight } \\
\text { Height } \\
\text { Hypertension } \\
\text { Socio-economic indicators }\end{array}$ & $\begin{array}{l}\text { Normal range }(18.5- \\
\left.24.99 \mathrm{~kg} / \mathrm{m}^{2}\right) \\
\text { Overweight }(25.00- \\
\left.29.99 \mathrm{~kg} / \mathrm{m}^{2}\right) \\
\text { Obese }\left(\geq 30 \mathrm{~kg} / \mathrm{m}^{2}\right)\end{array}$ & \\
\hline $\begin{array}{l}\text { Tuoyire et al. } \\
\text { (2018) }\end{array}$ & $\begin{array}{l}\text { Presence of TV } \\
\text { Frequency of viewing TV } \\
\text { Demographic variables }\end{array}$ & $\begin{array}{l}\text { BMI: (Underweight } \\
<18.50 \mathrm{~kg} / \mathrm{m}^{2} \\
\text { Normal range }(18.5- \\
\left.24.99 \mathrm{~kg} / \mathrm{m}^{2}\right) \\
\text { Overweight }(25.00- \\
\left.29.99 \mathrm{~kg} / \mathrm{m}^{2}\right) \\
\text { Obese }\left(\geq 30 \mathrm{~kg} / \mathrm{m}^{2}\right)\end{array}$ & $\begin{array}{l}\text { Women with TV in their households, and with high TV } \\
\text { exposure were significantly }(\mathrm{P}<0.05) \text { more likely (OR = } \\
1.39,95 \% \mathrm{Cl}=1.002,1.923) \text { to be overweight/obese } \\
\text { compared to those with no TV in their households, and } \\
\text { no TV exposure after controlling for confounders }\end{array}$ \\
\hline $\begin{array}{l}\text { Tyrovolas et al. } \\
(2016)\end{array}$ & $\begin{array}{l}\text { Age } \\
\text { Sex } \\
\text { Education }\end{array}$ & $\begin{array}{l}\text { BMI: (Underweight } \\
<18.50 \mathrm{~kg} / \mathrm{m}^{2} \\
\text { Normal range }(18.5-\end{array}$ & $\begin{array}{l}\text { Compared to high levels of physical activity, low levels } \\
\text { were related with higher odds for sarcopenia (OR } \\
=1.36,95 \% \mathrm{Cl}=1.11-1.67 \text { ) and sarcopenic obesity (OR }\end{array}$ \\
\hline
\end{tabular}




\begin{tabular}{|c|c|c|c|}
\hline Author (year) & Determining variables measured & Obesity specification & Findings \\
\hline & $\begin{array}{l}\text { Wealth } \\
\text { Current drinker } \\
\text { Current smoker } \\
\text { Physical activity } \\
\text { Number of chronic conditions }\end{array}$ & $\begin{array}{l}\left.24.99 \mathrm{~kg} / \mathrm{m}^{2}\right) \\
\text { Overweight }(25.00 \text { - } \\
\left.29.99 \mathrm{~kg} / \mathrm{m}^{2}\right) \\
\text { Obese }\left(\geq 30 \mathrm{~kg} / \mathrm{m}^{2}\right)\end{array}$ & $=1.80, \mathrm{Cl}=1.23-2.64)$ in the overall sample. \\
\hline $\begin{array}{l}\text { Ukegbu et al. } \\
\text { (2017) }\end{array}$ & $\begin{array}{l}\text { Age } \\
\text { Gender } \\
\text { Level in school } \\
\text { Monthly allowance } \\
\text { Number of meals } \\
\text { Consumption of unhealthy snack } \\
\text { foods } \\
\text { Soft drink consumption } \\
\text { Weekly alcohol consumption } \\
\text { Hypertension }\end{array}$ & $\begin{array}{l}\text { BMI: (Underweight } \\
<18.50 \mathrm{~kg} / \mathrm{m}^{2} \\
\text { Normal range }(18.5- \\
\left.24.99 \mathrm{~kg} / \mathrm{m}^{2}\right) \\
\text { Overweight }(25.00- \\
\left.29.99 \mathrm{~kg} / \mathrm{m}^{2}\right) \\
\text { Obese }\left(\geq 30 \mathrm{~kg} / \mathrm{m}^{2}\right)\end{array}$ & $\begin{array}{l}\text { Consumption of unhealthy snack foods }\left(X^{2}=13.39 \text {, }\right. \\
p=0.037) \text {, being female }\left(X^{2}=47.91, p=0.000\right) \text {, first year } \\
\text { student }\left(X^{2}=41.82, p=0.000\right) \text { and having high systolic } \\
\left(X^{2}=88.18, p=0.000\right) \text { and diastolic }\left(X^{2}=10.17, p=0.000\right) \\
\text { pressure were associated with obesity }\end{array}$ \\
\hline
\end{tabular}




\begin{tabular}{|c|c|c|c|}
\hline Author (year) & Determining variables measured & Obesity specification & Findings \\
\hline $\begin{array}{l}\text { Wahab et al. } \\
\text { (2011) }\end{array}$ & $\begin{array}{l}\text { age, } \\
\text { sex, } \\
\text { current history of alcohol or } \\
\text { tobacco use, } \\
\text { hypertension and } \\
\text { diabetes mellitus }\end{array}$ & $\begin{array}{l}\text { BMI: (Underweight } \\
<18.50 \mathrm{~kg} / \mathrm{m}^{2} \\
\text { Normal range (18.5- } \\
\left.24.99 \mathrm{~kg} / \mathrm{m}^{2}\right) \\
\text { Overweight }(25.00- \\
\left.29.99 \mathrm{~kg} / \mathrm{m}^{2}\right) \\
\text { Obese }\left(\geq 30 \mathrm{~kg} / \mathrm{m}^{2}\right)\end{array}$ & $\begin{array}{l}\text { female sex (OR 6.119, 95\% Cl 2.705-13.842, } \mathrm{p}<0.001 \text { ), } \\
\text { hypercholesterolaemia (OR 2.138, 95\% Cl 1.109- 4.119, } \\
\mathrm{p}=0.023 \text { ) and hyperuricaemia (OR } 2.906,95 \% \mathrm{Cl} 1.444- \\
5.847, \mathrm{p}=0.003 \text { ) were significantly associated with } \\
\text { obesity }\end{array}$ \\
\hline $\begin{array}{l}\text { Yaya et al. } \\
\text { (2018) }\end{array}$ & $\begin{array}{l}\text { Age } \\
\text { Residence } \\
\text { Educational level } \\
\text { Religion } \\
\text { Marital status } \\
\text { Wealth index } \\
\text { Working } \\
\text { Number of children }\end{array}$ & $\begin{array}{l}\text { BMI: (Underweight } \\
<18.50 \mathrm{~kg} / \mathrm{m}^{2} \\
\text { Normal range }(18.5- \\
\left.24.99 \mathrm{~kg} / \mathrm{m}^{2}\right) \\
\text { Overweight }(25.00- \\
\left.29.99 \mathrm{~kg} / \mathrm{m}^{2}\right) \\
\text { Obese }\left(\geq 30 \mathrm{~kg} / \mathrm{m}^{2}\right)\end{array}$ & 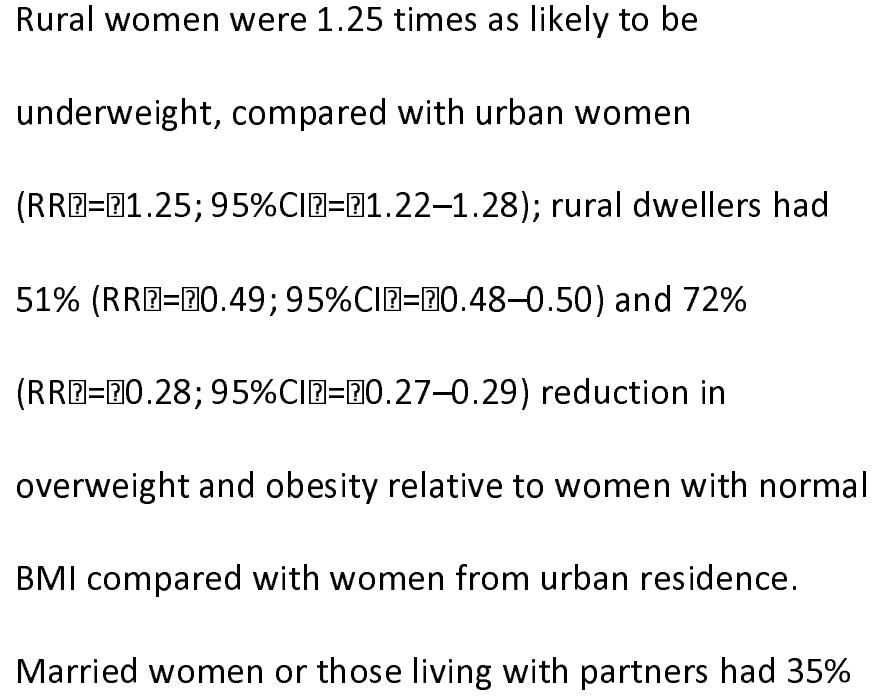 \\
\hline
\end{tabular}




\begin{tabular}{|c|c|c|c|}
\hline Author (year) & Determining variables measured & Obesity specification & Findings \\
\hline & $\begin{array}{l}\text { Alcohol consumption } \\
\text { Currently smoking } \\
\text { Exercise } \\
\text { Fruit consumption } \\
\text { Vegetable consumption }\end{array}$ & & 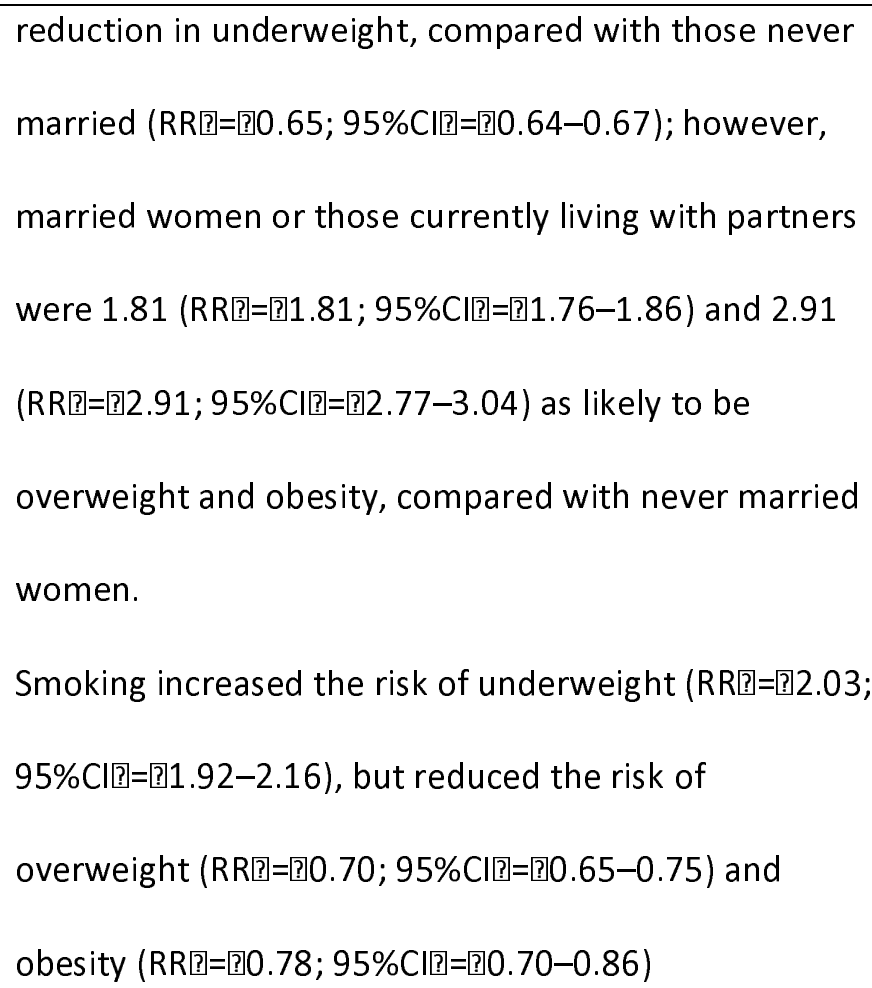 \\
\hline $\begin{array}{l}\text { Ziraba et al. } \\
\text { (2009) }\end{array}$ & $\begin{array}{l}\text { Wealth index/ Amenities } \\
\text { Time (in years) } \\
\text { Woman's education }\end{array}$ & $\begin{array}{l}\text { BMI: (Underweight } \\
<18.50 \mathrm{~kg} / \mathrm{m}^{2} \\
\text { Normal range }(18.5- \\
\left.24.99 \mathrm{~kg} / \mathrm{m}^{2}\right) \\
\text { Overweight }(25.00-\end{array}$ & $\begin{array}{l}\text { The odds ratio of the variable time lapse was } 1.05(p< \\
0.01) \text {, indicating that the prevalence of } \\
\text { overweight/obesity increased by about } 5 \% \text { per year on } \\
\text { average in the countries in the study. }\end{array}$ \\
\hline
\end{tabular}




\begin{tabular}{|l|l|l|l|}
\hline Author (year) & Determining variables measured & Obesity specification & Findings \\
\hline & & $\left.29.99 \mathrm{~kg} / \mathrm{m}^{2}\right)$ & \\
& & & \\
& & & \\
\end{tabular}

Significant associations indicate $p$-value $<0.05$ 


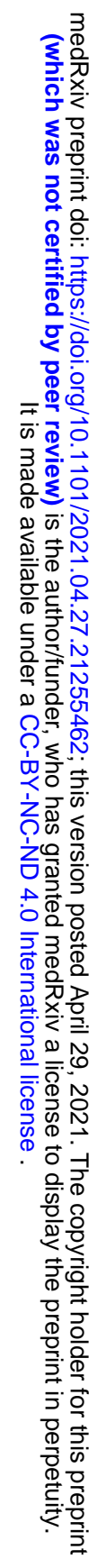


medRxiv preprint doi: https://doi.org/10.1101/2021.04.27.21255462; this version posted April 29, 2021. The copyright holder for this preprint (which was not certified by peer review) is the author/funder, who has granted medRxiv a license to display the preprint in perpetuity. It is made available under a CC-BY-NC-ND 4.0 International license.

Table 5: Heterogeneous findings on environmental determinants of obesity

\begin{tabular}{llll}
\hline Authors & Variables & Effect size & $95 \% \mathrm{Cl}$
\end{tabular}

offensive odors

density 
medRxiv preprint doi: https://doi.org/10.1101/2021.04.27.21255462; this version posted April 29, 2021. The copyright holder for this preprint (which was not certified by peer review) is the author/funder, who has granted medRxiv a license to display the preprint in perpetuity.

It is made available under a CC-BY-NC-ND 4.0 International license .

\begin{tabular}{llll}
\hline Authors & Variables & Effect size & $95 \% \mathrm{Cl}$
\end{tabular}

Walking and safety from crime $\quad-0.044$

at night

Total physical activity and

$-0.037$

residential density

Total physical activity and

$-0.076$

absence of garbage

Total physical activity and

$-0.083$

safety from crime at night

Dake et al. (2016)

Crime levels in community

1.19

Length of stay in community

$-1.73$

$*$

( $\geq 10$ years)

Number of convenience stores

0.168

Number of out-of-home

$-0.075$

cooked foods 
medRxiv preprint doi: https://doi.org/10.1101/2021.04.27.21255462; this version posted April 29, 2021. The copyright holder for this preprint (which was not certified by peer review) is the author/funder, who has granted medRxiv a license to display the preprint in perpetuity. It is made available under a CC-BY-NC-ND 4.0 International license.
Authors
Variables
Effect size
$95 \% \mathrm{Cl}$.

Bishwajit and Yaya (2018) Watching TV almost every day 2.7

$2.432-3.037$

Goryakin (2015)

Economic globalization

0.117

1.5

$1.053-1.63$

week

(second quartile)

Economic globalization

0.147

(third quartile)

Economic globalization

0.139

(fourth quartile) 
medRxiv preprint doi: https://doi.org/10.1101/2021.04.27.21255462; this version posted April 29, 2021. The copyright holder for this preprint (which was not certified by peer review) is the author/funder, who has granted medRxiv a license to display the preprint in perpetuity.

References

1. World Health Organisation. (2020). Obesity. https://www.who.int/healthtopics/obesity\#tab=tab_1. Accessed on 28/5/2020.

2. Hill, J. O., Peters, J. C., Catenacci, V. A., Wyatt, H. R. (2008). International strategies to address obesity. Obesity reviews, 9, 41-47.

3. Dalal, S., Beunza, J. J., Volmink, J., et al. (2011). Non-communicable diseases in subSaharan Africa: what we know now. International journal of epidemiology, 40(4), 885901.

4. World Health Organisation (2018). Noncommunicable diseases. https://www.who.int/news-room/fact-sheets/detail/noncommunicable-diseases. Accessed on $28 / 5 / 2020$.

5. World Health Organisation. (2014). Noncommunicable diseases: Campaign for action meeting the NCD targets. https://www.who.int/beat-ncds/take-action/targets/en/. Accessed on 29/5/2020.

6. World Health Organisation. (2018). Noncommunicable diseases and mental health. https://www. who.int/nmh/ncd-tools/who-regions-african/en/. Accessed on 28/5/2020.

7. Micklesfield, L. K., Lambert, E. V., Hume, D. J., et al. (2013). Socio-cultural, environmental and behavioural determinants of obesity in black South African women. Cardiovascular journal of Africa, 24(9), 369.

8. Ziraba, A. K., Fotso, J. C., Ochako, R. (2009). Overweight and obesity in urban Africa: a problem of the rich or the poor?. BMC public health, 9(1), 465.

9. Mayosi, B. M., Flisher, A. J., Lalloo, U. G., et al. (2009). The burden of noncommunicable diseases in South Africa. The lancet, 374(9693), 934-947.

10. United Nation Food and Agriculture Organization. (2019). Obesity on the rise in West Africa. http://www.fao.org/africa/news/detail-news/en/c/1187047/. Accessed on 04/12/2020. 
medRxiv preprint doi: https://doi.org/10.1101/2021.04.27.21255462; this version posted April 29, 2021. The copyright holder for this preprint (which was not certified by peer review) is the author/funder, who has granted medRxiv a license to display the preprint in perpetuity. It is made available under a CC-BY-NC-ND 4.0 International license .

11. Amugsi, D. A., Dimbuene, Z. T., Mberu, B., Muthuri, S., Ezeh, A. C. (2017). Prevalence and time trends in overweight and obesity among urban women: an analysis of demographic and health surveys data from 24 African countries, 1991-2014. BMJ open, 7(10), e017344. doi: 10.1136/bmjopen-2017-017344

12. Amoah, A. G. (2003). Obesity in adult residents of Accra, Ghana. Ethnicity \& disease, 13(2 Suppl 2), S97-101.

13. Antwi, E., Klipstein $\square$ Grobusch, K., Quansah Asare, G., Koram, K. A., Grobbee, D., Agyepong, I. A. (2016). Measuring regional and district variations in the incidence of pregnancy $\square$ induced hypertension in Ghana: challenges, opportunities, and implications for maternal and newborn health policy and programmes. Tropical medicine \& international health, 21(1), 93-100.

14. Bosu W. K. (2012). A comprehensive review of the policy and programmatic response to chronic non-communicable disease in Ghana. Ghana medical journal, 46(2 Suppl), 6978.

15. Dahlgren G., Whitehead M. (1993). Tackling social inequalities in health. https://www.euro.who.int/_data/assets/pdf_file/0018/103824/E89384.pdf. Accessed on 04/12/2020.

16. Obirikorang, Y., Obirikorang, C., Enoch, O. A., et al. (2016). Prevalence and risk factors of obesity among practicing nurses at three selected hospitals in Kumasi Metropolis, Ghana. Journal of Medical and Biomedical Sciences, 5(3), 45-55.

17. Sodjinou, R., Agueh, V., Fayomi, B., Delisle, H. (2008). Obesity and cardio-metabolic risk factors in urban adults of Benin: relationship with socio-economic status, urbanisation, and lifestyle patterns. BMC public health, 8(1), 84.

18. Addo, J., Smeeth, L., Leon, D. A. (2009). Obesity in urban civil servants in Ghana: association with pre-adult wealth and adult socio-economic status. Public health, 123(5), 365-370.

19. Aladeniyi, I., Adeniyi, O. V., Fawole, O., et al. (2017). The prevalence and correlates of pre-diabetes and diabetes mellitus among public category workers in Akure, Nigeria. The Open Public Health Journal, 10(1).

20. Ajayi, I. O., Adebamowo, C., Adami, H. O., D, et al. (2016). Urban-rural and geographic differences in overweight and obesity in four sub-Saharan African adult populations: a multi-country cross-sectional study. BMC Public Health, 16(1), 1126.

21. Cohen, E., Gradidge, P. J. L., Ndao, A., Duboz, P., Macia, E., Gueye, L., ChapuisLucciani, N. (2019). Biocultural determinants of overweight and obesity in the context of nutrition transition in Senegal: a holistic anthropological approach. Journal of biosocial science, 51(4), 469-490.

22. Peltzer, K., Pengpid, S., Samuels, T., et al. (2014). Prevalence of overweight/obesity and its associated factors among university students from 22 countries. International journal of environmental research and public health, 11(7), 7425-7441.

23. Lartey, S. T., Magnussen, C. G., Si, L., et al. (2019). Rapidly increasing prevalence of overweight and obesity in older Ghanaian adults from 2007-2015: Evidence from WHOSAGE Waves 1 \& 2. PloS one, 14(8), e0215045.

24. Chigbu, C. O., Parhofer, K. G., Aniebue, U. U., Berger, U. (2018). Prevalence and sociodemographic determinants of adult obesity: a large representative household survey in a resource-constrained African setting with double burden of undernutrition and overnutrition. J Epidemiol Community Health, 72(8), 702-707. 
25. Addo, P. N., Nyarko, K. M., Sackey, S. O., Akweongo, P., Sarfo, B. (2015). Prevalence of obesity and overweight and associated factors among financial institution workers in Accra Metropolis, Ghana: a cross sectional study. BMC research notes, 8(1), 599.

26. Macia, E., Duboz, P., Gueye, L. (2010). Prevalence of obesity in Dakar. Obesity Reviews, 11(10), 691-694.

27. Maruf, F. A., Udoji, N. V. (2015). Prevalence and socio-demographic determinants of overweight and obesity in a Nigerian population. Journal of epidemiology, JE20140099.

28. Wahab, K. W., Sani, M. U., Yusuf, B. O., Gbadamosi, M., Gbadamosi, A., Yandutse, M. I. (2011). Prevalence and determinants of obesity-a cross-sectional study of an adult Northern Nigerian population. International archives of medicine, 4(1), 1-5.

29. Boua, R. P., Sorgho, H., Rouamba, T., et al. (2018). Gender differences in sociodemographic and behavioural factors associated with BMI in an adult population in rural Burkina Faso-an AWI-Gen sub-study. Global health action, 11(sup2), 1527557.

30. Doku, D. T., Neupane, S. (2015). Double burden of malnutrition: increasing overweight and obesity and stall underweight trends among Ghanaian women. BMC public health, 15(1), 670.

31. Chinedu, S. N., Emiloju, O. C., Azuh, D. E., Ogunlana, O. O., Iheagwam, F. N. (2017). Association between age, gender and body weight in educational institutions in Ota, Southwest Nigeria. Asian Journal of epidemiology, 10(3), 144-149.

32. Nuertey, B. D., Alhassan, A. I., Nuertey, A. D., et al. (2017). Prevalence of obesity and overweight and its associated factors among registered pensioners in Ghana; a cross sectional studies. BMC obesity, 4(1), 26.

33. Pasquet, P., Temgoua, L. S., Melaman-Sego, F., Froment, A., Rikong-Adie, H. (2003). Prevalence of overweight and obesity for urban adults in Cameroon. Annals of Human Biology, 30(5), 551-562.

34. Yaya, S., Ekholuenetale, M., Bishwajit, G. (2018). Differentials in prevalence and correlates of metabolic risk factors of non-communicable diseases among women in subSaharan Africa: evidence from 33 countries. BMC Public Health, 18(1), 1168.

35. Nonterah, E. A., Debpuur, C., Agongo, G., et al. (2018). Socio-demographic and behavioural determinants of body mass index among an adult population in rural Northern Ghana: the AWI-Gen study. Global health action, 11(sup2), 1467588.

36. Tyrovolas, S., Koyanagi, A., Olaya, B., et al. (2016). Factors associated with skeletal muscle mass, sarcopenia, and sarcopenic obesity in older adults: a multi $\square$ continent study. Journal of cachexia, sarcopenia and muscle, 7(3), 312-321.

37. Luke, A., Bovet, P., Plange-Rhule, J., Forrester, T. E., Lambert, E. V., Schoeller, D. A., Brage, S. (2014). A mixed ecologic-cohort comparison of physical activity \& weight among young adults from five populations of African origin. BMC public health, 14(1), 397.

38. Damorou, F., Yayehd, K., N'cho Mottoh, M. P., et al. (2013). Prevalence and determinants of obesity among workers in Lome (Togo). Res J Cardiol, 6(1), 19-27.

39. Oyeyemi, A. L., Deforche, B., Sallis, J. F., De Bourdeaudhuij, I., Van Dyck, D. (2013). Behavioral mediators of the association between neighborhood environment and weight status in Nigerian adults. American Journal of Health Promotion, 28(1), 23-31.

40. Mogre, V., Nyaba, R., Aleyira, S., Sam, N. B. (2015). Demographic, dietary and physical activity predictors of general and abdominal obesity among university students: a crosssectional study. Springerplus, 4(1), 226. 
medRxiv preprint doi: https://doi.org/10.1101/2021.04.27.21255462; this version posted April 29, 2021. The copyright holder for this preprint

(which was not certified by peer review) is the author/funder, who has granted medRxiv a license to display the preprint in perpetuity. It is made available under a CC-BY-NC-ND 4.0 International license .

41. Becquey, E., Savy, M., Danel, P., Dabiré, H. B., Tapsoba, S., Martin-Prével, Y. (2010). Dietary patterns of adults living in Ouagadougou and their association with overweight. Nutrition Journal, 9(1), 13.

42. Dake, F. A., Thompson, A. L., Ng, S. W., Agyei-Mensah, S., Codjoe, S. N. (2016). The local food environment and body mass index among the urban poor in Accra, Ghana. Journal of Urban Health, 93(3), 438-455.

43. Osayomi, T., Orhiere, M. A. (2017). Small-area variations in overweight and obesity in an urban area of Nigeria: The role of fast food outlets. Bulletin of Geography. Socioeconomic Series, 38(38), 93-108.

44. Sidhu, S., Parikh, T., Burman, K. D. (2017). Endocrine changes in obesity. In Endotext [Internet]. MDText. com, Inc.

45. Gambineri, A., Pelusi, C. (2019). Sex hormones, obesity and type 2 diabetes: is there a link?. Endocrine connections, 8(1), R1-R9. https://doi.org/10.1530/EC-18-0450.

46. Novelle, M. G., Diéguez, C. (2019). Updating gender differences in the control of homeostatic and hedonic food intake: Implications for binge eating disorder. Molecular and cellular endocrinology, 110508.

47. Insenser, M., Murri, M., Del Campo, R., Martínez-García, M. Á., Fernández-Durán, E., Escobar-Morreale, H. F. (2018). Gut microbiota and the polycystic ovary syndrome: influence of sex, sex hormones, and obesity. The Journal of Clinical Endocrinology \& Metabolism, 103(7), 2552-2562.

48. Kozakowski, J., Gietka-Czernel, M., Leszczyńska, D., \& Majos, A. (2017). Obesity in menopause-our negligence or an unfortunate inevitability? Przeglad menopauzalny= Menopause review, 16(2), 61.

49. Al-Safi, Z. A., Polotsky, A. J. (2015). Obesity and menopause. Best Practice \& Research Clinical Obstetrics \& Gynaecology, 29(4), 548-553.

50. Frank, L., Kerr, J., Saelens, B., Sallis, J., Glanz, K., Chapman, J. (2009). Food outlet visits, physical activity and body weight: variations by gender and race-ethnicity. British Journal of Sports Medicine, 43(2), 124-131.

51. Afrifa-Anane, E., Agyemang, C., Codjoe, S. N. A., Ogedegbe, G., Aikins, A. D. G. (2015). The association of physical activity, body mass index and the blood pressure levels among urban poor youth in Accra, Ghana. BMC public health, 15(1), 269.

52. Kaczynski, A. T., Stanis, S. A. W., Hastmann, T. J., Besenyi, G. M. (2011). Variations in observed park physical activity intensity level by gender, race, and age: individual and joint effects. Journal of physical activity and health, 8(s2), S151-S160. https://doi.org/10.1123/jpah.8.s2.s151.

53. Wardle, J., Haase, A. M., Steptoe, A., Nillapun, M., Jonwutiwes, K., Bellisie, F. (2004). Gender differences in food choice: the contribution of health beliefs and dieting. Annals of behavioral medicine, 27(2), 107-116.

54. Kanter, R., Caballero, B. (2012). Global gender disparities in obesity: a review. Advances in nutrition, 3(4), 491-498.

55. Guthold, R., Cowan, M. J., Autenrieth, C. S., Kann, L., Riley, L. M. (2010). Physical activity and sedentary behavior among schoolchildren: a 34-country comparison. The Journal of pediatrics, 157(1), 43-49.

56. Wansink, B., Cheney, M. M., Chan, N. (2003). Exploring comfort food preferences across age and gender. Physiology \& behavior, 79(4-5), 739-747. 
medRxiv preprint doi: https://doi.org/10.1101/2021.04.27.21255462; this version posted April 29, 2021. The copyright holder for this preprint

(which was not certified by peer review) is the author/funder, who has granted medRxiv a license to display the preprint in perpetuity.

It is made available under a CC-BY-NC-ND 4.0 International license .

57. Aryeetey, R. N. O. (2016). Perceptions and experiences of overweight among women in the Ga East District, Ghana. Frontiers in nutrition, 3, 13.

58. Appiah C., Steiner-Asiedu M., Otoo G. (2014). Predictors of Overweight/Obesity in Urban Ghanaian Women. Int J Clin Nutr; 2(3):60-8.

59. Benkeser R. M., Biritwum R., Hill A. G. (2012). Prevalence of overweight and obesity and perception of healthy and desirable body size in urban, Ghanaian women. Ghana Med J; 46(2):66-75.

60. Frasca, D., Blomberg, B. B., Paganelli, R. (2017). Aging, obesity, and inflammatory agerelated diseases. Frontiers in Immunology, 8, 1745.

61. Jura, M., Kozak, L. P. (2016). Obesity and related consequences to ageing. Age, 38(1), 23.

62. Wagenmakers, A. J. (2016). Impact of physical activity, ageing, obesity and metabolic syndrome on muscle microvascular perfusion and endothelial metabolism. The Journal of Physiology, 594(8), 2205.

63. Vincent, H. K., Raiser, S. N., \& Vincent, K. R. (2012). The aging musculoskeletal system and obesity-related considerations with exercise. Ageing research reviews, 11(3), 361373.

64. Afshar, S., Roderick, P. J., Kowal, P., Dimitrov, B. D., Hill, A. G. (2015). Multimorbidity and the inequalities of global ageing: a cross-sectional study of 28 countries using the World Health Surveys. BMC public health, 15, 776. https://doi.org/10.1186/s12889-0152008-7.

65. Frisbee, J. C., Goodwill, A. G., Frisbee, S. J., Butcher, J. T., Wu, F., Chantler, P. D. (2016). Microvascular perfusion heterogeneity contributes to peripheral vascular disease in metabolic syndrome. The Journal of physiology, 594(8), 2233-2243.

66. Fruh S. M. (2017). Obesity: Risk factors, complications, and strategies for sustainable long-term weight management. Journal of the American Association of Nurse Practitioners, 29(S1), S3-S14. https://doi.org/10.1002/2327-6924.12510.

67. Akinpelu, A. O., Oyewole, O. O., Adekanla, B. A. (2015). Body size perceptions and weight status of adults in a Nigerian rural community. Annals of medical and health sciences research, 5(5), 358-364.

68. Ofori-Asenso, R., Agyeman, A. A., Laar, A., Boateng, D. (2016). Overweight and obesity epidemic in Ghana-a systematic review and meta-analysis. BMC Public Health, 16(1), 1239.

69. Omari R., Jongerden J., Essegbey G., Frempong G., Ruivenkamp G. (2013). Fast Food in the Greater Accra Region of Ghana: Characteristics, Availability, and the Cuisine Concept. Food Stud: An Interdisciplinary Journal;1(4):29-42.

70. Agyei-Mensah S., de-Graft Aikins A. (2010). Epidemiological transition and the double burden of disease in Accra, Ghana. J Urban Health; 87(5):879-97.

71. Ro, A., Osborn, B. (2018). Exploring Dietary Factors in the Food Insecurity and Obesity Relationship Among Latinos in California. Journal of health care for the poor and underserved, 29(3), 1108-1122.

72. Kruger H. S., Venter C. S., Vorster H. H., Margetts B. M. (2002). Physical inactivity is the major determinant of obesity in black women in the North West Province, South Africa: the THUSA study. Nutrition 18: 422-427. 
medRxiv preprint doi: https://doi.org/10.1101/2021.04.27.21255462; this version posted April 29, 2021. The copyright holder for this preprint (which was not certified by peer review) is the author/funder, who has granted medRxiv a license to display the preprint in perpetuity. It is made available under a CC-BY-NC-ND 4.0 International license .

73. Patel, O., Shahulhameed, S., Shivashankar, R., et al. (2018). Association between full service and fast food restaurant density, dietary intake and overweight/obesity among adults in Delhi, India. BMC Public Health, 18(1), 36.

74. Ford, N. D., Patel, S. A., Narayan, K. V. (2017). Obesity in low-and middle-income countries: burden, drivers, and emerging challenges. Annual review of public health, 38 , 145-164.

75. Mitchell, S., Shaw, D. (2015). The worldwide epidemic of female obesity. Best practice \& research Clinical obstetrics \& gynaecology, 29(3), 289-299.

76. Otang-Mbeng, W., Otunola, G. A., Afolayan, A. J. (2017). Lifestyle factors and comorbidities associated with obesity and overweight in Nkonkobe Municipality of the Eastern Cape, South Africa. Journal of Health, Population and Nutrition, 36(1), 22.

77. Burgoine, T., Sarkar, C., Webster, C. J., Monsivais, P. (2018). Examining the interaction of fast-food outlet exposure and income on diet and obesity: evidence from 51,361 UK Biobank participants. International Journal of Behavioral Nutrition and Physical Activity, 15(1), 71.

78. Fletcher, E. A., McNaughton, S. A., Crawford, D., Cleland, V., Della Gatta, J., Hatt, J., ... \& Timperio, A. (2018). Associations between sedentary behaviours and dietary intakes among adolescents. Public health nutrition, 21(6), 1115-1122.

79. Stranges, S. (2019). Epidemiological and nutritional transition in low-and middle-income countries: Saverio Stranges. European Journal of Public Health,29(Supplement_4), ckz185-199.

80. Hawkes, C. (2018). Globalization and the Nutrition Transition: A Case Study (101). Case Studies in Food Policy for Developing Countries: Institutions and International Trade Policies, 3, 113

81. Sartorius, B., Veerman, L. J., Manyema, M., Chola, L., Hofman, K. (2015). Determinants of Obesity and Associated Population Attributability, South Africa: Empirical Evidence from a National Panel Survey, 2008-2012.PloS one, 10(6), e0130218. https://doi.org/10.1371/journal.pone.0130218.

82. Ofori-Asenso R, Garcia D. (2016). Cardiovascular diseases in Ghana within the context of globalization. Cardiovasc Diagn Ther; 6(1):67-77.

83. Traversy, G., Chaput, J. P. (2015). Alcohol consumption and obesity: an update. Current obesity reports, 4(1), 122-130.

84. Sung, K. C., Kim, S. H., Reaven, G. M. (2007). Relationship among alcohol, body weight, and cardiovascular risk factors in 27,030 Korean men. Diabetes care, 30(10), 2690-2694.

85. Clair, C., Chiolero, A., Faeh, D., et al. (2011). Dose-dependent positive association between cigarette smoking, abdominal obesity and body fat: cross-sectional data from a population-based survey. BMC public health, 11(1), 23.

86. Tankó, L. B., Christiansen, C. (2004). An update on the antiestrogenic effect of smoking: a literature review with implications for researchers and practitioners. Menopause, 11(1), 104-109.

87. Wu, Y., Song, P., Zhang, W., et al. (2015). Activation of AMPK $\alpha 2$ in adipocytes is essential for nicotine-induced insulin resistance in vivo. Nature medicine, 21(4), 373-382.

88. Lakhan, S. E., \& Kirchgessner, A. (2011). Anti-inflammatory effects of nicotine in obesity and ulcerative colitis. Journal of translational medicine, 9(1), 1-10. 
medRxiv preprint doi: https://doi.org/10.1101/2021.04.27.21255462; this version posted April 29, 2021. The copyright holder for this preprint (which was not certified by peer review) is the author/funder, who has granted medRxiv a license to display the preprint in perpetuity. It is made available under a CC-BY-NC-ND 4.0 International license .

89. Chiolero, A., Jacot $\square$ Sadowski, I., Faeh, D., Paccaud, F., Cornuz, J. (2007). Association of cigarettes smoked daily with obesity in a general adult population. Obesity, 15(5), 1311-1318.

90. Leech, R. M., McNaughton, S. A., Timperio, A. (2014). The clustering of diet, physical activity and sedentary behavior in children and adolescents: a review. International Journal of Behavioral Nutrition and Physical Activity,11(1), 4. https://doi.org/10.1186/1479-5868-11-4.

91. Pearson, N., Biddle, S. J. (2011). Sedentary behavior and dietary intake in children, adolescents, and adults: a systematic review. American journal of preventive medicine, 41(2), 178-188. https://doi.org/10.1016/j.amepre.2011.05.002.

92. Van Der Horst, K., Oenema, A., Ferreira, I., et al. (2007). A systematic review of environmental correlates of obesity-related dietary behaviors in youth. Health education research, 22(2), 203-226.https://doi.org/10.1093/her/cyl069.

93. Nguyen, P., Le, L. K. D., Nguyen, D., et al. (2020). The effectiveness of sedentary behaviour interventions on sitting time and screen time in children and adults: an umbrella review of systematic reviews. International Journal of Behavioral Nutrition and Physical Activity, 17(1), 1-11.

94. Li, X., Memarian, E., Sundquist, J., Zöller, B., Sundquist, K. (2014). Neighbourhood deprivation, individual-level familial and socio-demographic factors and diagnosed childhood obesity: a nationwide multilevel study from Sweden. Obesity facts, 7(4), 253263.

95. Balhareth, A., Meertens, R., Kremers, S., Sleddens, E. (2019). Overweight and obesity among adults in the Gulf States: A systematic literature review of correlates of weight, weight $\square$ related behaviours, and interventions. Obesity Reviews, 20(5), 763-793. https://doi.org/10.1111/obr.12826. 
medRxiv preprint doi: https://doi.org/10.1101/2021.04.27.21255462; this version posted April 29, 2021. The copyright holder for this preprint (which was not certified by peer review) is the author/funder, who has granted medRxiv a license to display the preprint in perpetuity.

\author{
It is made available under a CC-BY-NC-ND 4.0 International license
.
}

